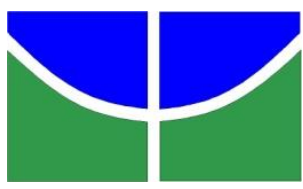

Universidade de Brasília

Instituto de Letras - IL

Departamento de Língua Estrangeira e Tradução - LET

Programa de Pós-Graduação em Linguística Aplicada - PGLA

Proposta Multimodal de uso de Vídeos Online no Planejamento de Tarefas para o Ensino de Português para Estrangeiros

Brasília, Janeiro de 2015 


\author{
Universidade de Brasília \\ Instituto de Letras - IL \\ Departamento de Línguas Estrangeiras e Tradução \\ Programa de Pós-Graduação em Linguística Aplicada - PGLA
}

\title{
Proposta Multimodal de uso de Vídeos Online no Planejamento de Tarefas para o Ensino de Português para Estrangeiros
}

Glauber Rodrigues de Queiroz

Orientadora: Profa. Dra. Janaína de Aquino Ferraz 


\author{
Universidade de Brasília \\ Instituto de Letras - IL \\ Departamento de Línguas Estrangeiras e Tradução - LET \\ Programa de Pós-Graduação em Linguística Aplicada - PGLA
}

Glauber Rodrigues de Queiroz

\title{
Proposta Multimodal de uso de Vídeos Online no Planejamento de Tarefas para o Ensino de Português para Estrangeiros
}

Dissertação apresentada como exigência parcial para obtenção do grau de MESTRE EM LINGUISTICA APLICADA ao Departamento de Línguas Estrangeiras e Tradução da Universidade de Brasília.

Orientadora: Profa ${ }^{a}$. Dr ${ }^{\text {a }}$ Janaína de Aquino Ferraz

Brasília 
QUEIROZ, Glauber Rodrigues. Proposta Multimodal de uso de Vídeos online no Planejamento de Tarefas para o Ensino de Português para Estrangeiros. Dissertação apresentada ao Departamento de Línguas Estrangeiras e Tradução da Universidade de Brasília para obtenção do grau de Mestre em Linguística Aplicada.

Aprovada em:

BANCA EXAMINADORA

Prof ${ }^{\mathrm{a}}$. Drà. Janaína de Aquino Ferraz (PPGL - UnB)

Presidente

Prof ${ }^{a}$. Dr ${ }^{a}$. Francisca Cordélia Oliveira da Silva (PPGL - UnB)

Membro

Prof. Dr. Augusto César Luitgards Moura Filho (PGLA - UnB)

Membro

Prof $\stackrel{a}{\text {. D }}{ }^{\mathrm{a}}$ José Carlos Paes de Almeida Filho (PGLA - UnB)

Suplente 
"A tarefa não é tanto ver aquilo que ninguém viu, mas pensar o que ninguém ainda pensou sobre aquilo que todo mundo vê. "

Arthur Schopenhauer 


\section{AGRADECIMENTOS}

Aos meus pais, Badia e Sales, por serem minhas referências maiores de caráter e seriedade diante dos desafios da vida.

Aos meus irmãos, Alysson, pela grande referência sobre estudos e por instigar em mim as primeiras investigações sobre línguas e culturas. Pollyanna, pela ternura e companheirismo no ramo das letras. Thiago, irmão mais novo, mas meu grande ombro amigo e companheiro.

Meu filho, Enzo, por estar presente em todos os meus atos e planejamentos, sendo sempre meu motivo para seguir adiante, firme.

À minha namorada, pela compreensão nos momentos de ausência, e companheirismo, sobretudo nas horas difíceis.

À Profa. Dra. Janaína de Aquino Ferraz, minha orientadora, um agradecimento especial: Janaína foi quem me iniciou em pesquisa, com o convite para os dois PIBICs durante a graduação, e me encorajou a ingressar no Mestrado. Foi o norte e o sul da minha pesquisa, e que sempre me apoiou em todas as etapas, muitas vezes servindo de psicóloga nas crises do processo.

À Profa. Dra. Josenia Antunes Vieira, pelos ensinamentos durante pesquisas de iniciação científica na graduação.

Às professoras Percília Santos, Verônica Vinecky e Márcia Niederauer, pelos ensinamentos na época do PEPPFOL.

Ao amigo Giuliano Castro, meu primeiro companheiro de pesquisa de iniciação científica, na graduação.

Ao amigo Fabrício Ademar, pelo encorajamento e influências para o mestrado.

Aos amigos Eliete e Marcos Alexandre, por sempre estarem disponíveis, solícitos e serem tão talentosos, me ajudando muito na realização desta pesquisa.

Aos colegas que cursaram comigo as disciplinas do Mestrado.

Aos professores do PGLA, Augusto Luitgards, Almeida Filho e Maria da Glória pelos ensinamentos durante o período de curso de disciplinas. 


\section{RESUMO}

Em tempos de grande profusão de imagens e de informações em rede fica latente a preocupação em repensar o ensino-aprendizagem de Português como Língua Estrangeira (PLE) de acordo com as regras da tecnologização pelas quais hoje o mundo passa. Apesar de a história humana ser marcada por um processo de constante busca por inovações tecnológicas, sem dúvida, hoje vivemos um boom tecnológico que traz consequências para as práticas discursivas em diversos campos do saber, entre elas, a do ensino de línguas. Como a área do PLE, se comparada com a tradição de ensino de outras línguas, ainda carece de muita atenção no que diz respeito a materiais didáticos, cabe ressaltar a importância de estudo que enfoque o uso das tecnologias para este ramo do ensino-aprendizagem. É com esse fim que propomos, nesta pesquisa, uma investigação pautada no uso de vídeos online para o ensino de PLE, com vistas a trabalho sistematizado na concepção de tarefas que envolvam esse tipo de tecnologia. A pesquisa tem caráter qualitativo-interpretativista, em que a análise privilegia a reinterpretação do corpus, (BAUER e GASKELL, 2003). A fundamentação teórica é composta por Teoria da Multimodalidade (KRESS e van LEEUWEN, 2006), Teoria do Ensino Baseado em Tarefas (NUNAN, $2004 \mathrm{e}$ WILLIS, 1996) e Letramento Midiático e Multiletramentos (KELLNER, 2008 e BEELAND, 2014). O Corpus foi composto por documentos da seguinte natureza: três vídeos online e duas unidades oriundas de dois diferentes livros didáticos para as quais foram propostas tarefas que envolvam vídeos. Pretendemos desvelar os processos de inserção dessa mídia em unidade didática de tema próximo aos vídeos selecionados, com objetivo de delinear caminho que mais se aproxime de uma proposta multimodal na qual as potencialidades de significado de diferentes recursos semióticos sejam melhor exploradas no ensino de PLE.

Palavras-chave: Multimodalidade; vídeos online; tarefas; português LE; letramento midiático; multiletramentos 


\begin{abstract}
In times of great profusion of images and information on the web, there is great concern in rethinking the teaching and learning of Portuguese as a Foreign Language (PFL) according to the rules of technologization through which the world is passing nowadays. Despite the human history has been marked by a process of constant search for technological innovations, there has been undoubtedly a technological boom that brings consequences to the discursive practices in many areas of knowledge, such as language teaching-learning. Comparing to the tradition of teaching the most commonly taught languages, the area of PFL still lacks attention in terms of didactic materials. Thus, it is relevant to highlight the importance of studies focusing the use of new technologies to teach in this area. With this goal, we propose in this work an investigation based on the use of online videos to teach PFL, in order to obtain a clear idea of the way to go concerning the Task-Based Language Teaching (TBLT) which involves this type of technology. This research has qualitative-interpretativist features, in which the analysis focuses the reinterpretation of corpus, (BAUER and GASKELL, 2003). The theoretical framework is triangularized in: Multimodality Theory (KRESS and van LEEUWEN, 2006); Task-based Language Teaching (NUNAN, 2004 and WILLIS, 1996); Media Literacy and Multiliteracies (KELLNER, 2008 e BEELAND, 2014). The corpus was composed by the following documents: three online videos and two lessons from two different books, for which we proposed tasks involving online videos. We intend to present the processes of insertion of this media in a book lesson whose theme is close to the ones in the videos, in order to identify the way that is coherent with the multimodal proposal, in which the meaning potentials are better explored in the area of teaching PFL.
\end{abstract}

Keywords: Multimodality; online videos; tasks; Portuguese as a Foreign Language; media literacy; multiliteracies 


\section{LISTA DE FIGURAS}

Figura 1 - Notícia sobre o uso de tecnologia digital em sala de aula 25

Figura 2 - Pesquisa geracional da população brasileira

Figura 3 - Pesquisa geracional da população brasileira 38

Figura 4 - Propaganda de nativos digitais como protagonistas do vídeo 39

Figura 5 - Vídeo de nativo digital como protagonista de tutorial sobre maquiagem para crianças 39

Figura 6 - Triangulação teórica entre Multimodalidade; Ensino baseado em Tarefas; Letramento Midiático e Multiletramentos 51

Figura 7 - Etapas metodológicas segundo Ferraz (2005) ........................ 67

Figura 8 - Primeira página da unidade 18 do livro Bem-Vindo .................... 82

Figura 9 - Sexta página da unidade 18 do livro Bem-Vindo 83

Figura 10 - Primeira página da lição 6 do livro Avenida Brasil 2 87

Figura 11 - Componentes do esquema de trabalho do Ensino Baseado em Tarefas 92

Figura 12 - Exercício do livro Avenida Brasil 2 sobre estereótipos ............. 93

Figura 13 - Imagem de uma furadeira ................................................. 94

Figura 14 - Imagem de um revólver ................................................ 95

Figura 15 - Imagem de uma pessoa de cor negra ................................ 95

Figura 16 - Imagem de uma pessoa de cor branca ................................ 96

Figura 17 - Imagem de um jovem imigrante nos Estados Unidos .............. 96

Figura 18 - Imagem de um jovem imigrante nos EUA e policiais .............. 97

Figura 19 - Exercício 7 da unidade 18 do livro Bem-Vindo ....................... 98

Figura 20 - Turistas em passeio de bugre em Porto de Galinhas (PE) .... 100 
Figura 21 - Turistas em piscina natural na praia de Porto de Galinhas (PE) 100

Figura 22 - Turistas em restaurante típico de praia no Brasil ................... 101

Figura 23 - Exercício 3 da lição 6 do livro Avenida Brasil 2 ..................... 102

Figura 24 - Turista mergulhando no mar da costa litorânea brasileira .... 103

Figura 25 - Representação da caipirinha ............................................ 104

Figura 26 - Brasileiros dançando ……............................................... 104

Figura 27 - Desfile de carnaval brasileiro ............................................ 105

Figura 28 - Cristo Redentor (RJ) ….............................................. 105 


\section{LISTA DE QUADROS}

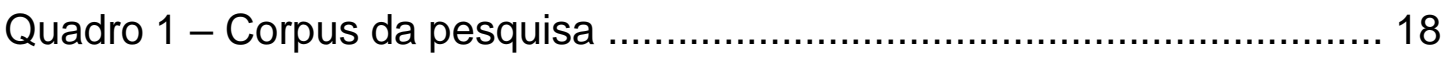

Quadro 7 - Ensino Baseado em Tarefas versus outras abordagens .......... 57

Quadro 8 - Sete princípios básicos do Ensino Baseado em Tarefas .......... 58

Quadro 9 - Usos inadequados dos vídeos em sala de aula ..................... 89 


\section{LISTA DE ABREVIATURAS E SIGLAS}

EFL English as a Foreign Language

ELBT Ensino de Línguas Baseado em Tarefas

ISP International Service Providers

LE Língua Estrangeira

PIBIC Programa Institucional de Bolsas de Iniciação Científica

PLE $\quad$ Português como Língua Estrangeira

TCP/IP Transmission Control Protocol / Internet Protocol

TIC Tecnologia de Informação e Comunicação

WAN Wide Area Networks 


\section{SUMÁRIO}

CAPÍTULO 1 - INTRODUÇÃO 15

CAPÍTULO 2 - APLICAÇÕES DE VÍDEOS ONLINE NO ENSINO DE LÍNGUAS: REFLEXÕES EM LINGUÍSTICA APLICADA

2.1 O VÍDEO ONLINE: O FLUXO DE DADOS NO PLANEJAMENTO DE AULAS DE PLE E O PAPEL DELE NA SOCIEDADE DE HOJE.

2.1.1 O advento da Internet e a mudança nas práticas de ensino ....... 22

2.1.2 Letramento midiático e multiletramentos 26

2.1.3 Mídias analógicas e mídias digitais: implicações para o letramento.

2.1.4 Sociedade baseada na informação ………………................ 34

2.1.5 Nativos digitais como aprendentes ........................................ 36

2.2 OBJETIVO GERAL, ESPECÍFICOS E PERGUNTAS DE PESQUISA ..... 40

2.3 O QUE OS VÍDEOS ONLINE PODEM DIZER A UM APRENDENTE DE LIINGUAS?

CAPÍTULO 3 - FUNDAMENTAÇÃO TEÓRICA …......................................... 47

3.1 O LUGAR DA PESQUISA MULTIMODAL NO ENSINO DE LE .............. 48

3.2 AS POSSIBILIDADES SEMIÓTICAS EM MULTIMODALIDADE ............. 51

3.3 O VÍDEO ONLINE: MONOMODAL VERSUS MULTIMODAL .................. 55

3.4 O TRABALHO COM TAREFAS: O PRÉ-TAREFA, A TAREFA EM SI, O

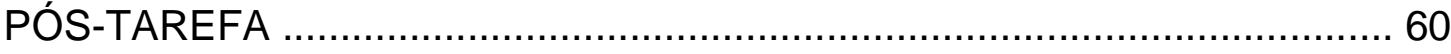

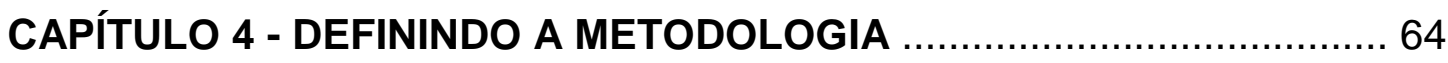

4.1 A PESQUISA QUALITATIVA: VANTAGENS PARA O ESTUDO DE ANÁLISE DOCUMENTAL EM MULTIMODALIDADE ….................................. 64

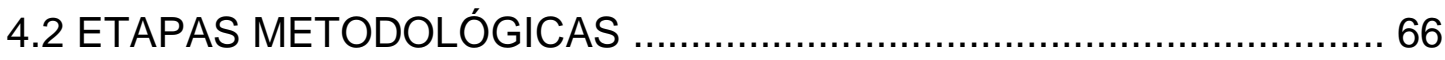

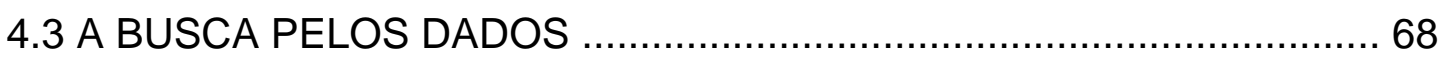

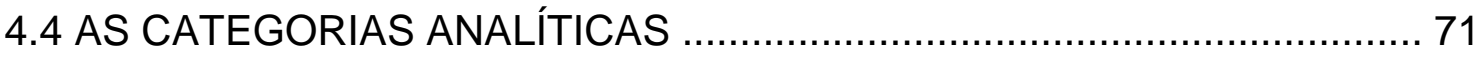


4.4.1 Categorias da Gramática Visual ............................................ 71

4.4.1.1 Participantes ............................................................... 71

4.4.1.2 O ponto de vista dos viewers ...................................... 72

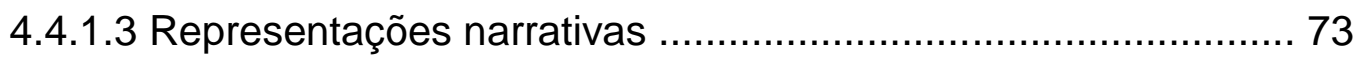

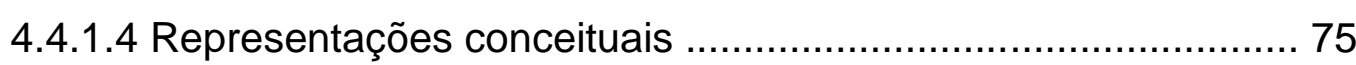

4.4.1.5 A composição espacial do significado ...................................... 76

4.4.1.6 A projeção a saliência ......................................................... 77

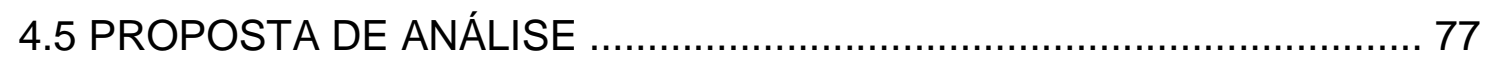

CAPÍTULO 5 - ANÁLISE DOS DADOS …………................................. 79

5.1 ESCOLHA DO CORPUS: AS UNIDADES EM DOIS LIVROS DE ENSINO DE PLE

5.1.1 Livro Bem-Vindo!: A Língua Portuguesa no Mundo da Comunicação 80

5.1.2 Livro Avenida Brasil 2: Curso Básico de Português para Estrangeiros 85

5.2 ESCOLHA DE TRÊS VÍDEOS ONLINE DO YOUTUBE: OUTRAS

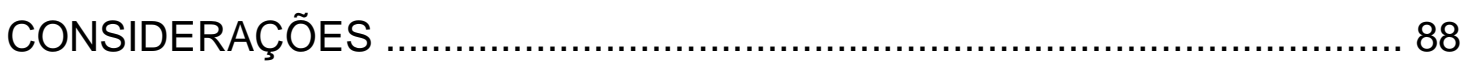

5.2.1 O vídeo online do YouTube "Preconceito e Estereótipo" ............ 90

5.2.2 O vídeo online do YouTube "Porto de Galinhas - CVC Viagens"

5.2.3 O vídeo online do YouTube "Coisas que os brasileiros sabem que são verdadeiras" 101

CONSIDERAÇÕES FINAIS. 107

REFERÊNCIAS. 111

ANEXOS 115 


\section{CAPÍTULO 1}

\section{INTRODUÇÃO}

Neste capítulo introdutório, gostaria de expor o porquê do uso da primeira pessoa do plural para me referir aos construtos deste trabalho. Quando escrevo "apresentamos", "temos por objetivo", "propomos", entre outros, estou apenas colocando no meu texto algumas vozes que auxiliaram, ou muitas vezes mais do que isso, guiaram, nortearam a trabalhosa, porém prolífica verticalização do que me propus a apresentar aqui. Portanto, fica aqui registrada nas linhas do texto homenagem aos professores, pesquisadores e colegas que contribuíram para a construção desta dissertação, em especial à minha orientadora, Profa. Dra. Janaína de Aquino Ferraz.

Assim, este trabalho nasce da necessidade de se ter parâmetros que possam guiar a prática docente no planejamento de tarefas para o ensino de PLE (Português como Língua Estrangeira) e que envolvam as chamadas TIC (Tecnologias da Informação e Comunicação).

Atualmente, professores de línguas veem-se confrontados com diversos recursos tecnológicos. No entanto, a inserção desses recursos requer conhecimento prévio sobre a potencialidade de significação de cada ferramenta para a otimização do processo de ensino-aprendizagem da língua-alvo.

Existe também o fato de, na área de ensino de PLE, ainda serem restritas as aplicações de recursos tecnológicos concebidos para este fim. O que normalmente se verifica é a adaptação da lógica de recursos tecnológicos desenvolvidos para o ensino de outras línguas, o que não necessariamente atende às demandas específicas do PLE.

Por meio do levantamento de materiais hoje existentes para o ensino de PLE, facilmente podemos verificar a quase inexistência de potencial para tarefas que envolvam diversidade tecnológica, o que não favorece um ensino de acordo com as demandas da atualidade, em que o leitor deve lidar com diferentes semioses simultaneamente. $O$ foco desse levantamento foi a inserção de vídeos 
online nas aulas de PLE, de forma a potencializar o trabalho feito com o uso de materiais didáticos, sobretudo o livro didático, que por si só não encerra as possibilidades da prática multimodal em sala de aula.

Hoje temos disponível no ambiente web canais de vídeos, como o YouTube, que surgiu em fevereiro de 2005. Neste canal, pessoas postam vídeos que muitas vezes, somando a sua totalidade, chegam a ser vistos mais de 2 bilhões de vezes por dia (WATKINS E WILKINS, 2011, p. 113). Como seu próprio slogan propõe, YouTube: "Broadcast Yourself", trata-se de um convite para que seus usuários tornem público o que quiserem, visando entretenimento, algum tipo de protesto, ensino-aprendizagem (aplicável a diferentes áreas do conhecimento), tutoriais, e até mesmo o compartilhamento de uma maneira prática de se dar nó de gravata. Apesar de questões sobre direitos de uso de vídeos e presença de eventuais obscenidades serem algo polêmico, a diversidade de conteúdos e a interatividade orgânica do público fazem do YouTube importante recurso para múltiplas práticas educacionais, o que, como iremos expor neste estudo, tem impacto direto na construção de significados de mundo por parte dos usuários, sobretudo dos aprendentes ${ }^{1}$ de Língua(s) Estrangeira(s), como é o foco desta pesquisa.

$\mathrm{Na}$ área do ensino de língua estrangeira, sobretudo a partir da década de 70, quando houve maior preocupação com a busca pela competência comunicativa, os participantes do processo em sala de aula, professor, aluno e terceiros envolvidos, deparam-se com algo em comum no que diz respeito ao objetivo final do aprendente: atingir nível de desdobramento comunicativo, de forma condizente com o mundo fora de sala de aula, que exige do falante muito

\footnotetext{
${ }^{1}$ A palavra "aprendente" foi apresentada em sala de aula da disciplina de Formação de Professores de LE, com o professor Dr. José Carlos P. de Almeida Filho, no Programa de Pós Graduação em Linguística Aplicada - Universidade de Brasília (PGLA-UnB) como um conceito que apoiamos e adotamos neste trabalho. Utilizamos aqui a palavra "aprendente" para designar não apenas o sujeito na condição de aluno, mas "aquele capaz de gerar pensamento através da construção simbólica, oportunizando assim o conhecimento de si e do mundo. A relação professor/aluno implica numa aprendizagem relacionada a conteúdos formais, visando resultados classificatórios. A relação ensinante/aprendente possui um modo subjetivo de ser, exige uma relação transferencial, um arquétipo de identidade com posicionamentos singulares do conhecer e aprender". (ALBUQUERQUE, R. N. A agulha e a linha, ensinante e aprendente: um momento autopoiético. www.construirnoticias.com.br/asp/materia.asp?id=2018. Acessado em 03/02/2015).
} 
mais do que o mero reconhecimento da forma da língua. Assim, é importante ressaltar 0 quanto 0 desenvolvimento de tarefas potencializa 0 ensinoaprendizagem da língua alvo em ambiente de sala de aula.

O ensino de línguas baseado em tarefas foi desenvolvido primeiramente por N. Prabhu na Índia. Prabhu propunha que os aprendentes adquiririam a língua de forma mais eficaz quando suas mentes estivessem focadas na tarefa ao invés da língua utilizada (PRABHU, 1987). O objetivo do ensino baseado em tarefas é expressar significado ao invés de manipular a forma (NUNAN, 2006). Para os professores de línguas sempre foi um desafio planejar aulas agradáveis e estimulantes, o que culminou em constante busca por elaboração de multimeios, e com o advento da facilidade de acesso e da quantidade de conteúdos da Internet, observa-se que cada vez mais o trabalho com vídeos tem sido de grande uso, tanto em momentos em que o professor planeja e se prepara para utilizar uma tarefa, o que aqui chamamos de pré-tarefa, como nos momentos de consolidação do que foi proposto e realizado na tarefa em si, o pós-tarefa, pois proporciona contato com diferentes variantes da língua-alvo, bem como a possibilidade de explorar áudio e imagens para facilitar o trabalho com determinada tarefa. Daí temos adiante o desafio de lidar com recursos semióticos de natureza diversa, que envolvam diferentes modalidades, como imagem, som e escrita.

No intuito de tratar do objeto de pesquisa de forma adequada, a proposta de pesquisa aqui lançada tem por base teoria que envolve Multimodalidade, Abordagem de Ensino Baseado em Tarefas e o Letramento Midiático e os Multiletramentos. A tecnologização do ensino de língua pressupõe algumas regras, pois com o boom tecnológico na área do ensino, o que não é exclusivo da área de línguas, temos consequências para as práticas discursivas em diversos campos do saber, sobretudo quando nos referimos ao ensino e aquisição de língua(gem).

Tendo lançado aqui a proposta do uso de vídeos online na aplicação das tarefas em sala de aula de PLE, surgem questões sobre como proceder com o uso desses vídeos, não necessariamente as perguntas da pesquisa, mas levando-nos até estas. Qual será o caminho a ser percorrido na concepção de tarefas que envolvam os vídeos online? Como guiar a prática docente em direção 
a uma atuação discursiva crítica, com foco no problema da construção de significados, na construção de sentidos, ao invés de preocupação somente com a forma da língua, e muitas vezes reforçando estereótipos?

Como escolhemos a Teoria da Multimodalidade (KRESS e van LEEUWEN, 2006), a Teoria do Ensino Baseado em Tarefas (NUNAN, 2004 e WILLIS, 1996) e o Letramento Midiático e os Multiletramentos (KELLNER, 2008 e BEELAND, 2014) para a fundamentação teórica e proposta metodológica, apresentaremos ao longo deste trabalho alguns caminhos para que possamos responder às respostas do parágrafo anterior.

Sabendo que a reflexão em Multimodalidade se dá em uma realidade social, nos vários significados e também no contexto que envolve o que e quem é pesquisado, reforçamos aqui a ideia de que seja mais condizente para o pesquisador desta área optar pela pesquisa de caráter qualitativointerpretativista, pois assim as análises podem privilegiar a reinterpretação do corpus (Bauer e Galkell, 2003). O quadro abaixo mostra a composição do corpus da pesquisa:

O corpus desta pesquisa foi composto por:

1) Duas unidades escolhidas em dois livros de ensino de PLE (uma unidade em cada livro). As unidades escolhidas são de dois livros bastante usados para o ensino de PLE: Bem-Vindo! A Língua Portuguesa no Mundo da Comunicação, cuja unidade escolhida foi a "Unidade 18: saindo de casa (p. 171 - 180) e Novo Avenida Brasil 2: Curso Básico de Português para Estrangeiros, cuja unidade escolhida foi a "Lição 6: de norte a sul (p. 55 - 66). As análises feitas em cada unidade serão melhor explicitadas posteriormente na seção sobre a proposta de análise.

2) Três vídeos online em Português do Brasil escolhidos no site YouTube para o planejamento das tarefas, sendo o primeiro vídeo para momento pré-tarefa, servindo de warm up (aquecimento), o segundo para a tarefa em si, e o terceiro para o pós-tarefa. Os vídeos escolhidos foram:

1) Preconceito e estereótipo (https://www.youtube.com/watch? $=7 \mathrm{~m}-\mathrm{yuzFljpc}$ ) para a unidade 18, exercício 7, página 176 do livro Bem Vindo!;

2) Porto de Galinhas, CVC Viagens (https://www.youtube.com/watch?v=O1frfxRmfWk) para a lição 6, seçãoA3, página 58 do livro Novo Avenida Brasil 2

3) Coisas que os brasileiros sabem que são verdadeiras (https://www.youtube.com/watch?v=Kd-sOVHWgpA) também para a lição 6, seção A3, página 58 , porém para o exercício 3 . "Como vocês veem a gente de seu país? (...).

Quadro 1: Corpus da pesquisa 
A finalidade das tarefas é potencializar os processos de inserção dos vídeos online em unidades didáticas de PLE em temas próximos aos dos vídeos selecionados, com o objetivo de configurar um caminho que mais se aproxime de uma proposta multimodal.

A seguir faremos uma exposição de cada capítulo desta dissertação, de forma a delinear o trabalho realizado e expor, ao final, os resultados atingidos. 


\title{
CAPÍTULO 2
}

\section{APLICAÇÕES DE VÍDEOS ONLINE NO ENSINO DE LÍNGUAS: REFLEXÕES EM LINGUÍSTICA APLICADA}

\begin{abstract}
Não podemos nos pôr diante de um aparelho de televisão "entregues" ou "disponíveis" ao que vier. Quanto mais nos sentamos diante da televisão - há situações de exceção - como, quem, de férias, se abre ao puro repouso e entretenimento, tanto mais risco corremos de tropeçar na compreensão de fatos e de acontecimentos. A postura crítica e desperta nos momentos necessários não pode faltar.
\end{abstract}

Paulo Freire, 1996, p. 140

Neste segundo capítulo, trataremos sobre o panorama do uso de vídeos no ensino de línguas. Para tanto, na seção 2.1, apresentamos o objeto de estudo, O vídeo online: o fluxo de dados no planejamento de aulas de PLE (doravante Português como Língua Estrangeira), em que traçaremos panorama histórico sobre o surgimento do vídeo online e o papel dele na sociedade hoje. Em seguida, apresentaremos os objetivos geral e específicos da pesquisa, bem como as perguntas de pesquisa. Na seção 2.3, faremos exposição concisa das possibilidades de relação entre o vídeo e o aprendiz de língua estrangeira.

\subsection{O VÍDEO ONLINE: O FLUXO DE DADOS NO PLANEJAMENTO DE AULAS DE PLE E O PAPEL DELE NA SOCIEDADE HOJE}

Ao longo de quase 15 anos de trabalho docente no ensino de línguas, que em princípio era guiado por prática mais intuitiva no ensino de Inglês como Língua Estrangeira (English as a Foreign Language - EFL) para brasileiros, pude despertar o interesse por pesquisas relacionadas à formação continuada, indagando sobre que teorias, competências de ensinar, estariam por vir no processo de formação do professor e também no momento pós-curso. Tais indagações fizeram-me ingressar no curso de graduação em Letras Português 
do Brasil como Segunda Língua, seguida pela de Ensino em Língua Inglesa. $\mathrm{Na}$ universidade, tive experiência, ainda como aluno de graduação, em dois projetos de iniciação científica (à época chamado PIBIC - Programa Institucional de Bolsas de Iniciação Científica, vinculado ao CNPq). Pude, assim, dar início à problematização sobre conhecimentos e competências que viabilizassem prática docente mais próxima da reflexividade crítica, de modo a poder posicionar-me em relação a abordagens de formação e de ensino de línguas. Paulo Freire (1996, p. 85) diz que "Como professor devo saber que sem a curiosidade que me move, que me inquieta, que me insere na busca, não aprendo nem ensino". Desde então, preocupo-me com o fato de que o pesquisador deve tornar público o que de alguma maneira o inquieta, como sinaliza Freire, e que tenha ligação com sua própria prática e pesquisas, que no meu caso é a constante preocupação em tornar minhas aulas motivadoras, relevantes e capazes de promover a consciência de que o processo de ensino-aprendizagem não pode ser algo mecânico, ou mera manipulação da forma da língua alvo, mas um processo focado nas construções de sentidos, com sistematização e objetivos bem articulados.

Depois de compreender melhor o processo de formação do professor de LE, assim como a importância de escolhas em relação à abordagem de ensinar língua(s), foi possível identificar algumas carências ainda presentes no ambiente de ensino-aprendizagem de línguas estrangeiras. Em vista da escassez de recursos digitais para o ensino de PLE, constatei que essa é uma área do conhecimento que ainda carece de estudos sistematizados que contemplem 0 trabalho com tecnologias, como, por exemplo, as digitais. Dessa feita, a proposta de pesquisa, ora apresentada, busca, de alguma forma, realizar investigação sobre como teorias da Multimodalidade e da Abordagem de Ensino baseado em Tarefas podem contribuir para a inserção de vídeos online em tarefas neste contexto de ensino, contribuindo assim para o trabalho docente calcado em reflexões e mudanças sociais.

O processo de aquisição em língua estrangeira requer diferentes estratégias para o desenvolvimento da competência comunicativa. Nesse contexto, cabe ao professor o planejamento de tarefas condizentes tanto com o 
conteúdo a ser trabalhado como com as demandas atuais, em que se espera um usuário de língua competente nas mais variadas esferas de uso da língua, não somente na modalidade escrita, mas nas diversas possibilidades multimodais.

Como estamos em meio a uma revolução tecnológica sem precedentes, no que tange à circulação e acesso à informação, é pertinente fazermos revisão sobre o impacto da Internet nas práticas de ensino, demanda que surge a partir das gerações cujos recursos estão permeados pelo ambiente digital, seja no uso dos smartphones no dia-a-dia, seja no uso de tecnologias digitais no ambiente de sala de aula, uma vez que pretendemos, aqui, tecer considerações a respeito da aplicação e potencialidades do vídeo online no planejamento de aula de língua(s).

\subsubsection{O advento da Internet e a mudança nas práticas de ensino}

Pensar em tecnologia digital e em como isso afeta práticas de ensino implica necessariamente em entender como ocorreu a disseminação de informação como a temos hoje e também em como a sociedade escolhe e acessa informação.

No período da Guerra Fria (1947 - 1953), surge como projeto de pesquisa militar, nos Estados Unidos, a Internet. Acredita-se que, por questão de contexto histórico e de relações conflituosas, o projeto da Internet tenha sido resposta do governo americano à criação do Sputnik² pela ex-União Soviética. Tendo como ideia inicial fazer uma ligação entre o Pentágono ${ }^{3}$ e universidades americanas,

${ }^{1} \mathrm{O}$ lançamento do primeiro satélite artificial à órbita terrestre, o Sputnik (que significa satélite em russo), em 03 de outubro de 1957, marcou o início da chamada corrida espacial entre EUA e URSS. A façanha colocava os russos em vantagem em relação aos EUA na tecnologia aeroespacial, intensificando os investimentos em pesquisa na área, o que resultou, em pouco mais de dez anos, no envio do homem ao espaço e na descida à Lua em 1969. (http://www.brasilescola.com/historia/sputnik.htm, acessado em 15/01/2015)

${ }^{3}$ Inaugurado em 1943, é um símbolo da defesa dos Estados Unidos e faz parte do Departamento de Defesa do país (http://www.infoescola.com/estados-unidos/pentagono-eua/, acessado em $15 / 01 / 2015)$ 
de forma que tornasse possível troca de informações rápidas e protegidas. Outra questão é, caso houvesse uma guerra nuclear, o país estaria resguardado em relação à sobrevivência de canais de informação. Naquele momento, não se pensava sobre os potenciais de crescimento dessa ferramenta, muito menos que atingiria as proporções hoje presentes na vida das pessoas.

Na época da criação da Internet, utilizou-se a tecnologia WAN (Wide Area Networks), porém, constatou-se que era muito complicada a linguagem utilizada nos computadores ligados em rede. Esse foi um dos motivos de, à época, não se imaginar o potencial de alastramento da Internet mundo afora (MERKLE e RICHARDSON, 2000).

Nos anos 70, com a criação do e-mail (electronic mail), iniciou-se o uso da Internet entre pesquisadores de diferentes instituições americanas, pois o acesso seria mais fácil, o que viabilizou a troca de informações dentro de centros universitários. Nos anos 80, iniciam-se aplicações comerciais da Internet. Os primeiros provedores de serviço da Internet foram os ISP (International Service Providers), assim o usuário comum teve acesso à rede de dentro de sua casa.

Um dos diferenciais da Internet em relação a outros meios de comunicação e telecomunicação, é que há uso de linguagem, ou protocolo, específico, o TCP/IP (Transmission Control Protocol / Internet Protocol). Este tipo de linguagem permite leitura da informação transmitida e a envia ao destino estabelecido pelo usuário. Com o lançamento do WWW (World Wide Web) em 1992, houve aumento substancial dos servidores conectados ao sistema, o que ocasionou adesão de milhares de usuários por todo o mundo, revolucionando a busca por informação por meio da pesquisa online. Esta é a criação do chamado ciberespaço, ou mundo virtual, em que o usuário se conecta a informações e pessoas sem precisar sair de casa ou do local de acesso.

Palfrey e Gasser (2011, p. 267) relatam fato ocorrido na Faculdade de Direito de Harvard na década de 1990, quando esta instituição resolvera investir bastante dinheiro para renovar e modernizar algumas salas de aula que já consideravam antigas, obsoletas. Entre outras modificações, resolveram instalar novas cadeiras, pois as anteriores remontavam a tempos em que o processo de ensino-aprendizagem era, assim como os assentos, duros e rígidos. Juntamente 
com a instalação das novas cadeiras, havia uma tomada para o uso de laptops. No entanto, houve coincidência das novas cadeiras com a era ponto-com, em que os alunos estavam passando por uma transição, abandonando tecnologias anteriores para se inserirem na Internet. Assim, a própria Faculdade de Direito de Harvard decidiu que o acesso à Internet seria ideal, o que causou problemas posteriores, pois não se sabia das proporções e efeitos do acesso à rede. Imediatamente após a instalação, o próprio corpo docente ordenou desinstalar as tomadas de acesso à Internet, alegando que não seria plausível que em aulas de ensino socrático sobre regras de direito houvesse uma classe cheia de alunos surfando na web.

Fazendo analogia entre o que ocorreu na Faculdade de Direito de Harvard e as escolas regulares, em todos os níveis de ensino, podemos constatar que aquela universidade está longe de estar sozinha. Muitas vezes, escolas distribuem os laptops entre os alunos, ou possibilitam o uso de Internet em sala de aula, mas não entendem muito bem o que fazer com tais computadores, ou por vezes lamentam o uso que os alunos fazem desses equipamentos. Atualmente, o grande desafio de algumas escolas é tentar dar utilidade ao uso dos smartphones com acesso à Internet, realizando algum tipo de proposta de didatização desse recurso, na busca de melhorar o acesso à rede para realização de atividades pedagógicas. O que observamos na mídia, são notícias sobre como a escola ainda se mostra dividida em meio à inserção de smartphones em seu cotidiano, pois encontrar entrada em sala de aula de forma sistematizada, reflexiva e crítica de tecnologia móvel demanda da comunidade escolar sintonia entre os discursos, de outra feita, o mais provável é que seja uma tarefa inútil. Como exemplo desse movimento de inserção de tecnologias digitais, vejamos a notícia publicada na página web do Correio Braziliense, datada de 06/03/2013, período em que o DF apresentou as primeiras iniciativas de uso de tecnologia móvel em sala de aula. 


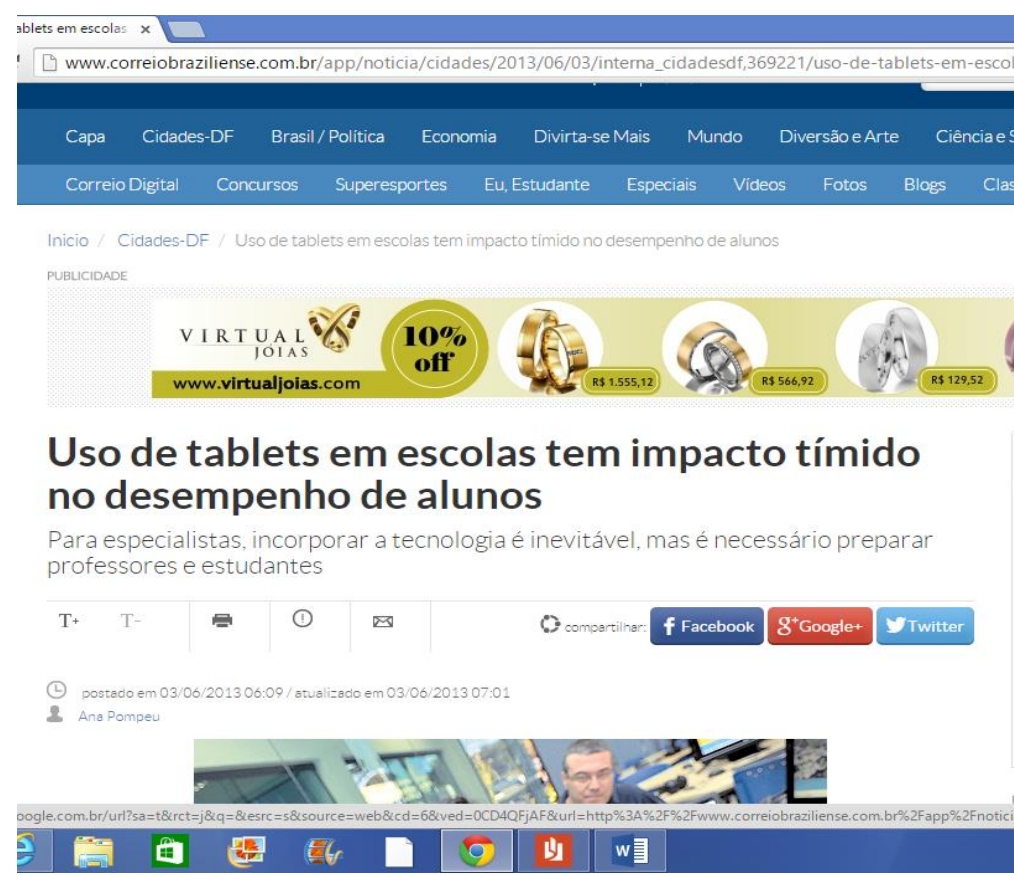

Figura 1 - Notícia sobre o uso de tecnologia digital em sala de aula ${ }^{4}$

O fato é que as inovações tecnológicas trazem implicações (positivas ou não), que são incondicionais. Tais implicações podem ser revertidas em algo que contribui para o desempenho das funções da educação na contemporaneidade. Dentre outros contributos, há o desenvolvimento pleno do educando, no que tange a preparação para o pleno exercício da cidadania e qualificação para 0 mercado de trabalho. A incorporação das tecnologias digitais no âmbito da educação traz implicações diversas e, em muitos casos, as inovações tecnológicas são confundidas com inovações pedagógicas, como afirma Mill (2010). O fato do indivíduo conhecer e dominar as tecnologias digitais, além de ter mais facilidade de acesso, passou por supervalorização, a ponto de podermos considerar que, na atualidade, bem-estar não mais está associado (somente) a apropriar-se de bens e riquezas materiais, mas sim ao acesso à informação, que por sua vez potencializa as relações de poder e dominação nos grupos sociais. Temos, então, novas reflexões sobre o que seria o "discurso tecnológico", em que há primazia à informação, ao conhecimento, ao saber, que

\footnotetext{
${ }^{4}$ Fonte consultada: http://www.correiobraziliense.com.br/app/noticia/cidades/2013/06/03/interna_cidadesdf,369221/ uso-de-tablets-em-escolas-tem-impacto-timido-no-desempenho-de-alunos.shtml. Acesso em 07/01/2015.
} 
estão diretamente relacionados com os processos formativos das escolas e da educação como um todo.

Nessa linha, passaremos a discutir um pouco mais sobre o que significa ter acesso a tecnologias da informação, em outras palavras, ser letrado em mídias.

\subsubsection{Letramento Midiático e Multiletramentos}

Para iniciarmos esta seção, devemos destacar que o conceito de letramento, "saber ler e escrever", vem mudando ao longo dos séculos. O uso da palavra "alfabetizado" tem sido problematizado por linguistas e pesquisadores da área de educação.

Soares (2009) firma que, a partir de práticas que surgem ao final do século XX e início do século XI, o indivíduo dito "alfabetizado" não é só e exclusivamente aquele que domina as práticas de leitura e escrita. Surge, então, a necessidade da distinção entre "alfabetização" e "letramento".

A tecnologia da leitura e escrita distingue indivíduos entre analfabetos e alfabetizados, isso sob o ponto de vista do grafocentrismo. $\mathrm{O}$ analfabeto sendo aquele que não sabe ler e escrever, não tem acesso aos bens das sociedades letradas, não conseguindo exercer plenamente seus direitos de cidadão. Já o alfabetizado é o indivíduo que sabe ler e escrever, que adquiriu e dominou a tecnologia da leitura e escrita. Porém, é aqui que surge a importância de enfatizarmos que ser alfabetizado não significa ser letrado. Ser letrado, além da condição de dominar a leitura e a escrita, também tem a ver com os usos desse domínio, da interação nas práticas sociais e da construção da identidade do próprio indivíduo. O indivíduo letrado, além de ler e escrever, responde de forma adequada e versátil às intensas demandas sociais por meio do uso amplo, dinâmico e diferenciado da leitura e escrita.

Em se tratando de um ponto de vista meramente quantitativo ou estatístico, desde o Brasil Colônia, há a preocupação sobre a questão do número de analfabetos no país, termo que surge para designar aquele que não atinge as 
expectativas em relação a ler e a escrever. Portanto, é exatamente a grande proporção do problema do analfabetismo que faz com que não haja discussão sobre a necessidade de se responder às exigências de leitura e de escrita que a sociedade faz continuamente.

Ainda sobre a realidade brasileira, conforme 0 uso das práticas linguísticas foi se tornando menos cunhado fortemente pela oralidade, e cada vez mais focado na escrita, percebeu-se que mesmo as pessoas que de alguma forma dominavam o conhecimento do código alfabético não haviam necessariamente adquirido a competência necessária para se envolverem efetivamente em práticas sociais de leitura e de escrita. Com o desenvolvimento político, social, econômico e cultural do país, houve a necessidade de se somar ao vocabulário da Língua Portuguesa o termo letramento.

A palavra letramento no Brasil surge como uma tradução do inglês literacy, do latim littera (letra) mais o sufixo - cy que adicionado às palavras indica estado, condição ou qualidade. Dessa feita, aqui no Brasil, adota-se o termo letramento para designar o indivíduo que não só sabe ler e escrever, mas que exerce e cultiva as práticas sociais de leitura e de escrita que permeiam a sociedade.

Segundo Soares (2009) há uma diferença entre países em desenvolvimento, como o Brasil, e países desenvolvidos, no que tange ao combate aos índices do não letramento (illiteracy). No caso dos desenvolvidos, não se trata de analfabetismo, uma vez que na maioria desses países o índice é praticamente zero. O que os preocupa é que os indivíduos não se encontram em estado ou condição de quem faz uso adequado do ler e do escrever, não incorporam os usos da escrita, não se apropriam plenamente das práticas sociais de leitura e de escrita.

Durante algum tempo, sobretudo no Brasil, educar as pessoas para a mídia, tendo como foco principal o meio educacional, foi basicamente proteger as crianças e jovens contra o problema da nocividade advinda dos meios de comunicação, o que para alguns críticos serviu como preservação dos meios impressos e valorização da leitura. O que se destaca, hoje, a esse respeito, é uma grande presença de textos advindos da mídia, em especial a jornalística, 
principalmente nas disciplinas de língua materna. Os PCN (Parâmetros Curriculares Nacionais) no Brasil fizeram uma tentativa de propor à escola textos que aparecem com certa frequência na realidade social, em especial os jornalísticos, para serem analisadas suas formas de recepção e de produção. No entanto, essa tentativa parou no uso da mídia simplesmente como ferramenta didática, que por vezes substituiu o livro texto em aulas de língua materna, ou outras vezes trazendo insumo para as aulas de outras disciplinas. A perspectiva de educação com a mídia vem sendo analisada minuciosamente por pesquisadores das áreas de educação e letramentos, como é o caso de Soares (2004, p. 5 - 7) e Kleiman (1995) que desenvolveram trabalhos sobre letramento midiático, partindo de uma diferenciação entre os dois termos Letramento e Alfabetização. Em princípio, estudos que se relacionavam ao Letramento Midiático limitavam-se a uma "alfabetização visual", com projetos voltados para a interpretação de imagens (HOBBS, 2009, p. 3). Dessa feita, o que se relacionava a letramento midiático e educação midiática era entendido como uma espécie de defesa contra sensacionalismos e formas de propaganda abusiva por parte dos meios de comunicação. Já a partir da década de 1960, novos aparatos tecnológicos com fins criativos e educacionais começam a ser utilizados por grupos de educadores nos Estados Unidos.

A partir dos anos 1970, a educação midiática passa a ser reconhecida, finalmente, como prática crítica de cidadania (HOBBS, 2009, p. 3). Já nos anos 1980, depois de escrever "Teaching the Media" (MASTERMAN, 1985), educadores que trabalhavam com mídia e educação e/ou educação em mídia começaram a adotar conceitos-chave, resumidos pelo Center for Media Literacy (Centro para Letramento Midiático - tradução livre) nos Estados Unidos. Daí, compreende-se que todas as mensagens midiáticas são construídas, usando-se uma linguagem criativa com suas próprias regras. Há também o fato de que diferentes pessoas experimentam a mesma mensagem midiática de maneiras diferentes e específicas. Assim, a mídia incorpora valores a pontos de vista distintos, e também se pensa sobre a questão de que muitas mensagens midiáticas estão organizadas com vistas à obtenção de lucro e/ou poder. 
Assim, o letramento midiático vai chegando a uma orientação participativa, passando a valorizar a produção social, a comunicação para desenvolvimento de conhecimentos, a interatividade e os diálogos (PÉREZ TORNEIRO \& VARIS, 2012, p. 67). Organizações e centros de pesquisas da área de letramentos midiáticos, como é o caso da Unesco, consideram que esse tipo de letramento é uma forma de "empoderar" a cidadania, servindo como chave para o desenvolvimento pleno da liberdade de expressão e do direito à informação. Há especialistas da área de letramento midiático que, inclusive, contrapõem-se às ideias de Prensky sobre os nativos digitais. Por exemplo, Buckingham (2009) afirma que muitos dos chamados nativos digitais são meros usuários mais intensivos de mídia digital, estando praticamente no mesmo grupo dos chamados imigrantes digitais. Tal afirmação intenciona chamar atenção a questões mais complexas em relação ao que se considera letramento digital. $O$ fato de estarem mais naturalizados e fazerem uso mais intenso de meios digitais não significa que, automaticamente, sejam proficientes em todos os aspectos dessas mídias, a ponto de, por exemplo, dominar competências e habilidades suficientes para lidar com esses novos aparatos digitais ao seu redor.

Para concluir esta parte, é importante que esbocemos algumas questões em relação ao que chamamos de Multiletramento. É ingênuo considerarmos a prática de leitura de forma totalmente isolada, sendo incrementada apenas com livros e textos impressos, pois tal visão não condiz com a realidade dos estudantes, sobretudo os da era digital. Hoje, o estudante é um cidadão integral, imerso em uma complexa realidade comunicacional, que em sua maior parte é tomada por meios digitais e audiovisuais. Se há preocupação em fomentar e encorajar o letramento pleno desses jovens, é necessário que se trabalhe a questão do multiletramento.

Ao considerarmos as críticas em relação aos plenos conhecimentos da geração digital, entendemos que é necessário que a escola de hoje ensine a compreender como funciona um jornal, um site de um programa de televisão. Isso significa que devemos oferecer competências críticas aos alunos sobre o mundo comunicacional e cultural que os cerca, o que, consequentemente, pode ajudar essas crianças e jovens a melhor decifrarem o que leem em textos 
encontrados na imprensa, pois tal leitura exige conhecimentos prévios sobre 0 entorno social, histórico e cultural. Enfrentar os desafios das novas tecnologias não é trabalho simples, mas devemos partir do ponto de pensar os novos letramentos, que incluem vários tipos de mídia, inclusive o "velho" jornal impresso.

Estar alfabetizado de acordo com os códigos da escrita não é mais suficiente. $\mathrm{O}$ aluno deve estar preparado para decifrar os inúmeros tipos de mensagens, sabendo dar tratamento crítico e interpretação adequada a cada um. $O$ ato de ler o mundo global, então, transcende os limites tradicionais da página escrita, pois há o auxílio da tecnologia, que permite que haja 0 desenvolvimento de competências que extravasam as fronteiras da palavra, aliando sons e imagens, muitas vezes em movimento, que instalam universos imaginários de forma mais profícua.

Kellner e Share (2008) falam da promoção de uma variedade de novos tipos e modelos de alfabetizações múltiplas, no sentido de capacitar os alunos tornando a educação relevante diante das exigências já do presente, e também do futuro. Há três questões relevantes, pois não se deve esquecer que o letramento midiático envolve o conhecimento de como a mídia funciona, como seus significados são construídos e como essas nuances funcionam também na vida cotidiana. Young (2012, p. 73) enfatiza que o letramento midiático "é uma porta de entrada para $\circ$ uso mais frequente e prático de alfabetização tradicional". Letramento midiático envolve, entretanto, aquisição de conhecimentos e competências para leitura e interpretação de todo tipo de texto, sendo condição necessária para a capacitação do indivíduo para participarem efetivamente na política, economia, cultura, considerando os âmbitos local, nacional e global (KELLNER, 2004). No entanto, mesmo depois de toda essa explanação sobre os novos caminhos e abordagens em relação às novas práticas sociais advindas da necessidade do letramento midiático, não devemos esquecer as capacidades, habilidades e estratégias necessárias para a leitura e compreensão das "velhas mídias". O ensino, a prática e o trabalho com o texto escrito, impresso, ainda seguem extremamente importantes. Trazer hábitos de interpretação das mídias digitais para as impressas talvez não funcione. É 
necessário ir além, formando um bom leitor de mídia, de todas elas, de forma que compreendam as particularidades de cada uma. Este sim é um bom parâmetro para que se entenda a questão dos multiletramentos.

Para que possamos dar continuidade às discussões sobre o entendimento e o preparo mais condizente com a era do multiletramento, a próxima discussão deste trabalho é sobre a questão das mídias, digitais, analógicas e se há, para este estudo, necessidade de realizar um contraste entre elas, para entender melhor o letramento midiático.

\subsubsection{Mídias Analógicas e Mídias Digitais: implicações para o letramento}

Ao pensarmos na Internet como suporte que alarga as possibilidades de interação comunicativa dos usuários, temos, consequentemente, o surgimento de várias mídias digitais, que se configuram, mesmo que baseados ou provenientes de mídias anteriores, analógicas. A literatura online convida o leitor a muitas possibilidades dentro do universo digital. Nesse ambiente, diferentes atores desempenham papéis diversos, produzem sentidos em conjunto, surgindo, então, o papel autoral tanto dos produtores quanto dos receptores, tornando, assim, os usuários sujeitos não passivos, mas parte integrante de toda a prática comunicativa.

É necessário que se discuta o significado de mídias para que tenhamos esclarecidas as relações de significação em diferentes contextos, considerando, aqui, o paralelo off-line/online. Em termos de produção de sentidos, há intrínseca implicação multimodal no que diz respeito às mídias, já que estas são formadas por diferentes semioses, destacando aqui verbal, visual e sonora, partindo do conceito de mídia, de acordo com três abordagens, a saber:

1) media effects (a partir dos estudos empíricos a que nos referimos, realizados no início por Lippmann, Lazarsfeld e outros, sob influência da Social Science, ainda que hoje tenham sofisticados métodos e abordagens), 2) media audiences and culture (estudos de recepção a partir da abordagem dos estudos culturais na década de 1970) e 3) political economy of media/media institutions (a partir de uma perspectiva da crítica social e da análise do papel das instituições da mídia no 
processo democrático). Segundo David L. Swanson, professor da Universidade do Illinois (Urbana), o campo da Comunicação nos Estados Unidos é composto por um número diverso de subcampos "que são conectados não só intelectualmente mas politicamente pela organização dos departamentos de Comunicação, a maioria deles estabelecidos logo após o fim da Segunda Guerra Mundial". (GUAZINA, 2007, p. 53 - 54)

Vemos que não se trata de conceito referente ao canal de veiculação de informação somente, mas sim de conceito que abrange a forma como essa informação passa a ser processada e direcionada. Santaella (2003, p.31) aponta que ao se falar sobre cultura de mídias deve-se esclarecer que uma das características primordiais é a ênfase que se coloca na informação como elemento substancial de todo processo comunicativo.

A outra questão que levantamos como ponto de partida para estudos que envolvam mídias é a natureza diversificada delas. Aqui elegemos diferenciar analógicas e digitais, o que se justifica pelo fato de cada uma corresponder respectivamente ao ambiente off-line e online.

Como podemos encontrar em definições de dicionários, temos 0 entendimento de que analógico está relacionado a analogia, que por sua vez significa fazer uma comparação. Portanto, algo analógico é aquilo que se compara a coisas reais, como, por exemplo, o relógio de ponteiros faz analogia à posição do sol. Por outro lado, o termo digital está relacionado a dígitos, números. Assim, o que é digital funciona por meio de decodificação de códigos numéricos. O meio digital se utiliza de processamento de dados armazenados e possuem informações digitalizadas. Os objetos digitais trazem as mesmas informações dos analógicos, mas sem fazer uma analogia ao real. Por exemplo, um texto digitalizado pode ter exatamente o mesmo conteúdo de um texto analógico (impresso), mas sem ser visto em papel.

As mídias analógicas precisam de suporte para reprodução. Elas precisam de meio concreto que as reproduzam. Já as digitais não precisam de suporte, mas de bits, que são as menores quantidades de informação que podem ser processadas por um sistema computacional. As mídias analógicas são editadas de forma manual, sendo sujeitas a erros, que são dificilmente corrigidos. 
Já as digitais podem ter sua edição alterada ou desfeita, não é linear e cada código possui um decodificador diferente. A armazenagem das mídias analógicas ocupa mais espaço do que a das digitais, que por sua vez são mais compactas. A distribuição do analógico é limitada, possuindo contato físico. Já a do digital é livre, não precisa de proximidade para que seja recebida, e não depende de um meio geográfico, podendo ter domínio mundial. As chamadas "multimídias" (multi = mais de um, muitos; midia = meio, entre o emissor e o receptor) também podem ser analógicas ou digitais. As analógicas têm como característica não possuírem tanta interatividade. As digitais possuem interatividade e têm retorno em tempo real.

Hoje, o que se requer em termos de leitura, passa pelo entendimento de que ler significa ir além do simples exercício de decodificar a escrita. Segundo Vieira (2007, p. 19):

O uso da tecnologia digital para ler, escrever e divulgar informações transformou radicalmente a natureza da comunicação escrita e o letramento convencional, introduzindo novos gêneros textuais, práticas discursivas e estabelecendo um novo paradigma nas ciências da linguagem.

Ainda segundo a mesma autora, no que se refere a impactos da tecnologia eletrônica no exercício da leitura e escrita, diferentemente do que se pensava com o advento da Internet, houve uma revalorização da escrita no ambiente online, apenas sendo necessário considerar que a visão dicotômica do oral e do escrito realmente não faz sentido para a compreensão da interface online, outras semioses estão intrinsecamente envolvidas na produção de sentidos, o que nos leva a considerar o letramento midiático como requisito para a leitura nesse ambiente virtual, e também devemos levar em conta que os multiletramentos passam pelo que Xavier e Santos (2005, p. 30) chamam de estratégias ou mecanismos coletivos de solução de problemas. Assim, passamos a entender que os participantes são corresponsáveis pela elaboração, divulgação de conteúdos na World Wide Web (www), ambiente em que usuários sem grandes conhecimentos de informática interagem em larga escala. 


\subsubsection{Sociedade Baseada na Informação}

A busca contínua por formas mais adequadas para o ensino de línguas estrangeiras tem dialogado com pesquisas sobre textos (aqui compreendendo o verbal, o imagético e o sonoro) em ambiente digital. Nesse ínterim, surgem os vídeos online figurando como textos visuais e dos quais podemos tirar proveito em termos de aprendizagem. Apesar de cada vez mais o vídeo estar presente em diversos níveis de ensino no cotidiano das escolas, entendemos que não há uma normatização em relação a seu uso, sobretudo no contexto do ensino de LE. É necessário que saibamos o potencial de influência deste recurso para a aprendizagem de línguas, em especial no que diz respeito às semioses nele presentes.

Não há dúvida de que há bastante interesse por parte de professores em utilizar essas novas mídias em sala de aula. Porém, há de se concordar que os profissionais dessa área de ensino devem capacitar-se. O embasamento teóricometodológico é algo que ainda falta para que essas práticas docentes se realizarem plena e criticamente. O potencial das mídias existentes na rede é algo que ainda carece de conhecimento por parte dos docentes, de forma que seja possível uma aprendizagem dinâmica, agradável e significativa para cada grupo específico de aprendizes da LE.

Inicialmente, como proposto para esta seção, discutiremos um pouco acerca deste objeto de estudo ora eleito: o vídeo online, mais especificamente os postados no YouTube.

De acordo com o projeto Vídeo Online, do site www.memelab.com.br, os vídeos online são arquivos digitais de vídeos, que também são chamados de "contêiners", pois eles encapsulam trilhas de áudio e imagem, ou seja, armazenam os bytes relativos ao som e imagem em movimento, codificados de uma determinada maneira.

Os vídeos online possuem mecanismos de codificação/decodificação utilizados na compressão das trilhas: os codecs, que são definidos no momento de compactação/conversão dos arquivos. Em relação aos resultados de 
qualidade e compressão dos vídeos, cada formato de arquivo suporta codecs específicos para som e imagem, o que torna importante a escolha de um determinado formato. Isso também define a extensão que deverá ser utilizada para salvar o arquivo final.

As informações técnicas sobre o que compõe um vídeo online podem ser de grande valia para que usuários dessas mídias possam compreender melhor o que define a qualidade de um vídeo digital, fazendo o melhor uso possível deste meio como forma de expressão, fonte de aprendizado e também para entretenimento.

Neste trabalho, propomos citar o site YouTube como um suporte para muitos gêneros, dando ênfase especial às multimodalidades relativas a som, imagem e movimento. O YouTube é um site na Internet que permite aos usuários carregarem, assistirem e compartilharem vídeos em formato digital. De acordo com informações do próprio site www.youtube.com/yt/about/pt-BR/, "(...) 0 YouTube é onde milhões de pessoas descobrem e compartilham vídeos originais e os assistem. O YouTube oferece um fórum para as pessoas se conectarem, informarem e inspirarem outras pessoas por todo o mundo e atua como uma plataforma de distribuição para criadores de conteúdo original e grandes e pequenos anunciantes".

O site YouTube foi fundado em fevereiro de 2005, por três pioneiros de um outro site da Internet ligado ao gerenciamento de doações. Os primeiros dois anos do YouTube foram extremamente prolíficos, o que o rendeu popularidade rápida a ponto de ser considerado a melhor invenção do ano, pois serviu de nova forma para as pessoas se entreterem, educarem, e também se chocarem com a facilidade de acesso a tanta informação disponibilizada.

Milhares de novos vídeos são colocados diariamente por internautas e à disposição destes. As regras para se realizar um upload são fáceis e práticas, pois basta que o vídeo tenha um tamanho de até $100 \mathrm{MB}$ ou duração de 10 minutos, e o usuário deve ser previamente cadastrado no YouTube.

Tendo em vista que a disponibilidade e acessibilidade de interação no YouTube desperta bastante fascínio nos usuários da Internet, o que também 
desperta grande profusão do seu uso por parte de professores, acredito que haja, aqui, um lugar especial para a reflexão acerca da sintonização da prática docente com as discussões atuais em relação ao ensino de língua(gem) e dos pressupostos da Teoria da Multimodalidade, fazendo com que haja cada vez menos espaço para prática intuitiva e ingênua. Na próxima seção, sobre o objetivo geral e os específicos, assim como as perguntas de pesquisa, farei uma exposição sobre a busca por uma operacionalização dos vídeos online no ensino de PLE.

\subsubsection{Nativos Digitais como Aprendentes}

Com os avanços da Internet, houve necessidade de reorganização por parte das escolas sobre a maneira pela qual ensina(va)m. Tendo em seus ambientes de aprendizagem uma nova geração de aprendentes, os nativos digitais, a escola teve, e ainda tem, que se reestruturar, tanto fisicamente como pedagogicamente. Os agentes envolvidos no processo de ensino-aprendizagem precisam dialogar, pois considerando este novo formato educacional, ambos têm vozes e a interação é feita, também e cada vez mais, com o uso de mídias digitais.

Santaella $(2003,2010)$ nomeia o século XXI como a Sociedade Digital, marcada, principalmente, pelos avanços tecnológicos e pelo surgimento de um novo tipo de criança: os nativos digitais. Esses chamados nativos digitais têm intimidade com meios digitais de forma a possuírem habilidades e competências para realizarem múltiplas tarefas ao mesmo tempo. Dessa forma, essa geração de nativos mudou, significativamente, os rumos da comunicação, o que surtiu efeito, consequentemente, na educação. Não podemos, então, pensar a educação e a comunicação em geral sob pontos de vista retrógrados, desconsiderando tais nuances, pois a forma de ser, agir e pensar da sociedade mudaram. Portanto, temos uma nova geração de aprendentes que interagem com as novas e velhas mídias. 
$O$ instituto de pesquisas IBOPE trata as gerações $Y$ e $Z$ como a "Juventude Digital". Ao se referir sobre as gerações do Brasil e suas respectivas faixas etárias - Baby Boomers (acima de 46 anos), Geração X (30 a 45 anos), Geração Y (20 a 29 anos), Geração Y (20 a 29 anos) e Geração Z (12 a 19 anos). As gerações $\mathrm{Y}$ e $\mathrm{Z}$ representam, $23 \%$ e $18 \%$ da população brasileira, respectivamente, como podemos ver no quadro abaixo:

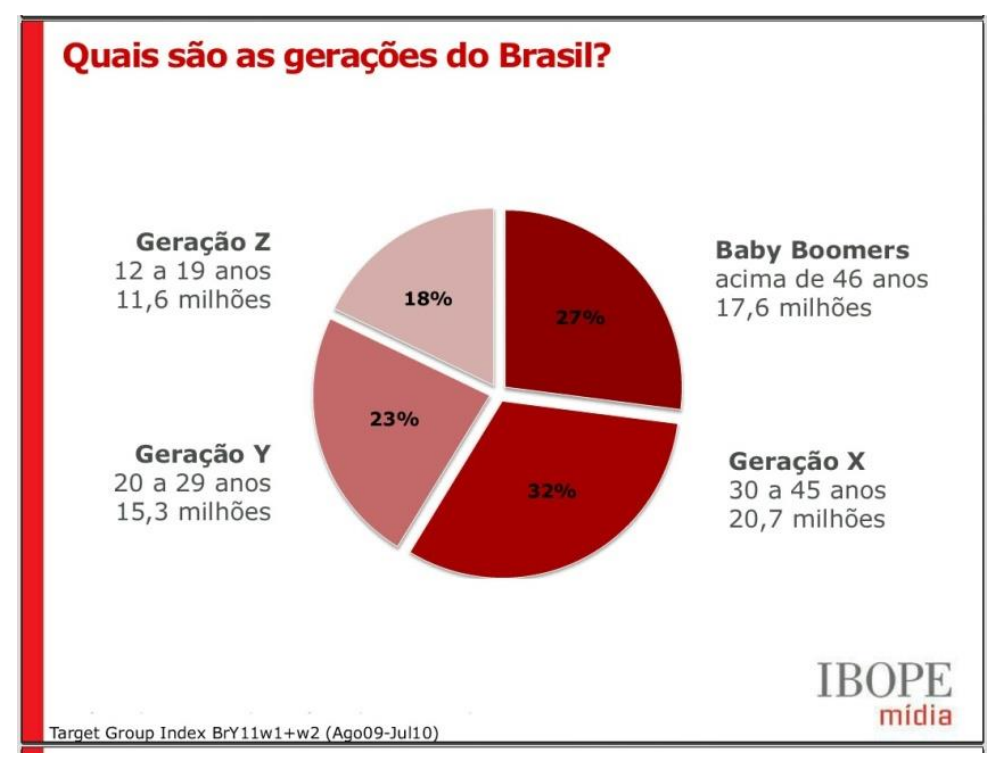

Figura 2 - Pesquisa geracional da população brasileira - Fonte - IBOPE mídia

Ao constatarmos que a geração digital, também conhecida por Geração Y e Geração Z, cresce em um mundo onde o papel fundamental da compreensão da realidade e da formação desses jovens é cada vez mais a cargo da comunicação digital, torna-se extremamente importante pensar e agir em relação às potencialidades dessas novas mídias de forma mais condizente com tal realidade, para melhor proceder em relação às competências e habilidades sensoriais, verbais e visuais que os aprendentes possuem e utilizam para se comunicarem.

Para Prensky (2001), os nativos digitais possuem, como características principais, capacidade de realizar múltiplas tarefas. Trata-se de indivíduos que não se amedrontam ou se embaraçam quando têm desafios relacionados às Tecnologias da Informação e da Comunicação (TICs), de forma a 
experimentarem e vivenciarem de maneira bastante natural as múltiplas possibilidades de novos aparatos digitais, como podemos perceber no quadro do IBOPE a seguir:

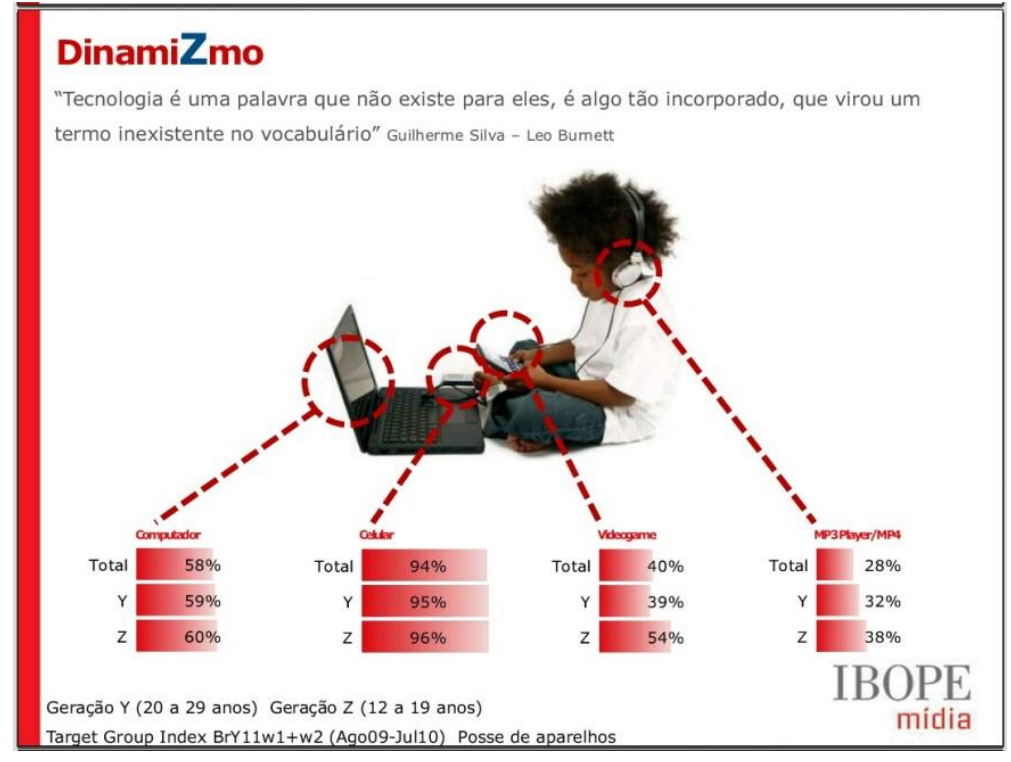

Figura 3 - Pesquisa geracional da população brasileira - Fonte - IBOPE mídia

Acreditamos, então, ser necessário, pensando nesse aspecto, que tal fascínio pela descoberta e experimentação pode e deve ser encorajado e trabalhado nos ambientes de aprendizagem, sobretudo de línguas, para que a interação e diálogos sejam a tônica da abordagem principal desse ramo da aquisição de língua(gem).

Ao analisarmos alguns vídeos online no site YouTube, podemos encontrar crianças e jovens da Juventude Digital interagindo como protagonistas tanto em vídeos de propaganda como em tutoriais ensinando a vestir, maquiar, lidar com jogos eletrônicos, e várias outras situações em que se evidencia a sua capacidade inata de realizar e desenvolver suas próprias narrativas audiovisuais sem o auxílio, necessariamente, de uma agência ou de uma empresa, sobretudo os vídeos produzidos em casa, onde não há evidências de adultos interagindo com as crianças. Percebe-se que tanto a editoração dos vídeos (produção, roteiros, etc.) como recursos de câmera, música, e efeitos são elementos bastante sofisticados. Abaixo podemos ver dois vídeos online do YouTube, que 
qualquer usuário pode ter acesso. No primeiro, trata-se de dois nativos digitais como protagonistas de uma propaganda do Banco Itaú; no segundo, há uma nativa digital dando dicas sobre como fazer maquiagem para crianças. Os dois vídeos, cujas figuras vêm em seguida, servem para elucidar os argumentos supracitados.

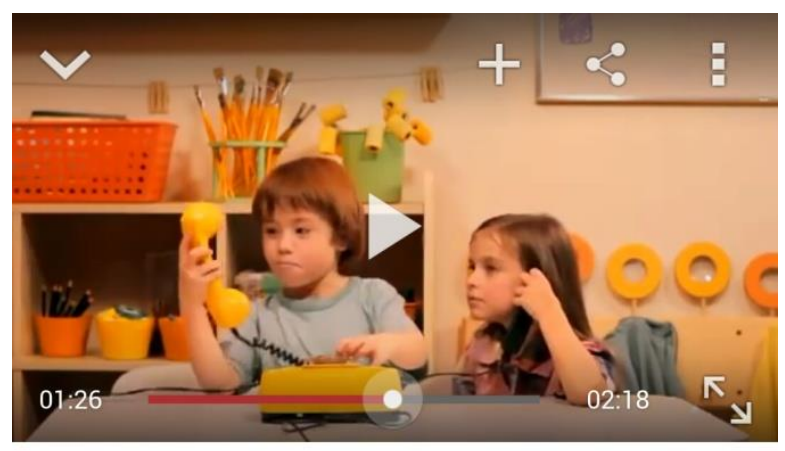

Comercial Itaú - crianças e a evolução tecnológica

124.251 visualizações

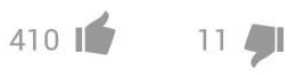

Figura 4 - Propaganda de nativos digitais como protagonistas do vídeo
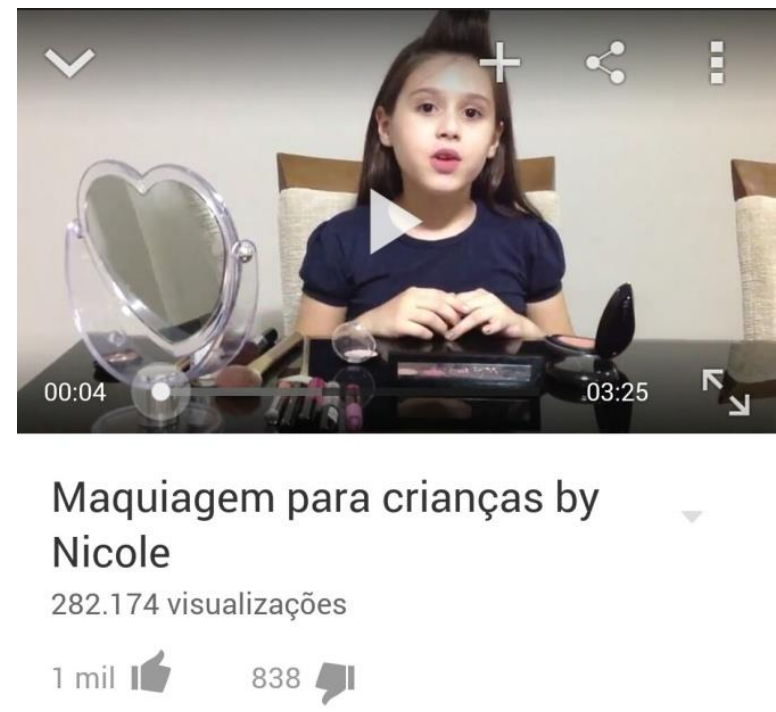

Figura 5 - Vídeo de nativo digital como protagonista de um tutorial sobre maquiagem para crianças 
Assim, na próxima seção, para dar visão macro da pesquisa, trataremos dos objetivos deste trabalho (geral e específicos) e também das perguntas de pesquisa, com o intuito de esclarecer os procedimentos adotados.

\subsection{OBJETIVO GERAL, OBJETIVOS ESPECÍFICOS E PERGUNTAS DE PESQUISA}

Como objetivo geral, o trabalho aqui realizado busca:

\section{Objetivo geral:}

- Investigar, por meio da Multimodalidade, da Abordagem de Ensino Baseada em Tarefas e do Letramento Midiático e Multiletramentos, a operacionalização de vídeos online em unidades de livros didáticos de PLE.

Para melhor detalhar o objetivo maior do trabalho, apresentamos a seguir os objetivos específicos:

\section{Objetivos específicos:}

- Chegar a conclusões sobre o tipo de vídeos online que apresentem condições ideais para operacionalização de tarefas no ensino-aprendizagem de PLE de acordo com os preceitos da Teoria da Multimodalidade.

- Categorizar formas de situar o trabalho com vídeos online nos momentos de realização da tarefa.

- Elucidar como os recursos semióticos presentes nos vídeos selecionados podem ser contemplados na realização das tarefas para o ensinoaprendizagem de PLE.

O critério de seleção dos vídeos é baseado na ideia de que cada recurso semiótico potencializa a realização de tarefas para o ensino-aprendizagem de PLE, considerando-se a construção de sentidos no ambiente de sala de aula, 
considerando o tema a ser tratado. Para tanto, procederemos com a seleção dos vídeos online na perspectiva de que estes possibilitem trabalho estruturado. É importante ressaltar que esta seleção tem como fio condutor os processos de significação em Português como Língua Estrangeira dos recursos semióticos presentes tanto nos vídeos online como nos livros didáticos.

No intuito de esclarecer os procedimentos a serem adotados, apresentamos as perguntas de pesquisa que norteiam o trabalho:

\section{Perguntas de pesquisa:}

1. Que tipo de vídeos online apresentam condições ideais para operacionalização de tarefas no ensino-aprendizagem de PLE de acordo com os preceitos da Teoria da Multimodalidade?

2. Como situar o trabalho com vídeos online nos momentos de realização da tarefa?

3. Como os recursos semióticos presentes nos vídeos selecionados podem ser contemplados na realização das tarefas para o ensino-aprendizagem de PLE?

Tendo em mente que o caminho da pesquisa pode sempre nos trazer novas possibilidades, acrescentamos a seguir prévia e brevemente panorama sobre como a análise multimodal de vídeos pode ser alternativa plausível para 0 planejamento de aulas com mídias digitais.

\subsection{O QUE OS VÍDEOS PODEM DIZER A UM APRENDENTE DE LÍNGUAS?}

Esta pesquisa visa trazer algumas observações importantes no tocante aos resultados alcançados ao longo da análise, o que pode apontar novos caminhos para os estudos voltados para recursos tecnológicos no ensino de língua estrangeira, assim como suscitar reflexão sobre a importância de conhecimento estruturado para a leitura multimodal em ambiente escolar de LE. Faremos um contraponto entre a importância de determinados vídeos para o 
trabalho em sala de aula e o processo de significação e ressignificação no ensino-aprendizagem de PLE, problematizando sobre quais vídeos e como esses vídeos podem potencializar o trabalho com tarefas que preconizem a leitura multimodal.

A primeira pergunta para esta pesquisa diz respeito a que vídeos online apresentam condições ideais para operacionalização de tarefas no ensinoaprendizagem de PLE. O que este trabalho irá focar é exatamente como os vídeos podem potencializar o trabalho multimodal, dentro de abordagem de ensino baseado em tarefas.

Já que citamos aqui que vídeos potencializam o uso de recursos semióticos diversos, esses passam a ser a tônica para elaboração de tarefas no ensino de PLE. Apresentamos aqui, como contextualização, conjunto de conceitos que explicitam, suscintamente, a questão da Multimodalidade. Walsh (2011, p. 105-106) traz uma lista de termos relacionados à Multimodalidade: Multimodality (Multimodalidade), Multiliteracies (Multiletramentos), Multimodal Literacy (Letramento Multimodal), Multimodal Texts (Textos Multimodais), Multimodal Learning Environments (Ambientes Multimodais de Aprendizagem) e New Literacies (Novos Letramentos). 
A partir dos apontamentos desta autora, podemos dizer que tais termos consistem, de forma bem resumida, em:

- Multimodalidade: estudo sobre o processo comunicativo. Aborda a questão de como o significado é comunicado por meio de diferentes recursos semióticos, e ainda, como os significados são construídos em Multiletramentos.

- Multiletramentos: estratégias comunicativas que são necessárias para que ocorra comunicação em diferentes contextos sociais.

- Letramento Multimodal: leitura simultânea, processamento, escrita, concepção, produção e interação com vários modos de operacionalização da linguagem, seja ela impressa, imagética, com ou sem movimento, com gráficos, animações, som, música e gestos.

- Textos Multimodais: são textos com mais de um modo de operacionalização, sejam escritos, imagéticos, com som, com movimento. Por vezes, trata-se de textos digitais, mas também podem ser livros com imagens, textos, gráficos. Enfim, são textos que trazem Ambientes Multimodais de Aprendizagem.

- Ambientes Multimodais de Aprendizagem: ambientes de aprendizagem (na maioria das vezes a sala de aula), onde professores e aprendentes estão interagindo com diferentes tipos de textos e tarefas, por meio de várias áreas do conhecimento e significação de novos letramentos.

- Novos Letramentos: termo usado para descrever de que forma as novas tecnologias estão criando novos letramentos e que (agora) incorporam as mudanças sociais e culturais que surgem juntamente com as mudanças na alfabetização e nas práticas de comunicação. 
A segunda pergunta norteadora desta pesquisa questiona como situar o trabalho com vídeos online na realização da tarefa. É necessário que pensemos sobre a utilização que pode ser feita de determinada mídia e os aspectos relacionados à prática em sala de aula. E ainda, se tal trabalho poderá trazer discussão sobre formação linguística que favoreça e propicie análise crítica da prática em sala de aula, privilegiando trabalho eficaz em relação ao texto multimodal e à forma de trabalhar as significações do mundo.

Nesta parte da pesquisa, é relevante explicitar a ligação entre a elaboração de tarefa para ensino de PLE e o que fazer com vídeo selecionado para ser utilizado nesse processo. Um vídeo online é instrumento/recurso multimodal, pois permite que o input, que segundo Ellis (1995) é produto linguístico direcionado ao aprendente de LE, apresentado tanto por falante nativo como por não-nativo da língua-alvo, seja apresentado de diferentes formas semióticas, privilegiando vários estilos de aprendizagem. Sendo assim, o vídeo pode ser utilizado antes da tarefa, funcionando como aquecimento para um tema, ou também pode servir de elemento motivacional para iniciar determinado assunto. Pode também ser utilizado durante a tarefa, caso esta seja de reconhecimento de assuntos ou tópicos, como quando os aprendentes assistem dois ou mais vídeos e os comparam e contrastam, em relação a assunto, semelhanças, diferenças, entre outros. $O$ vídeo também pode ser utilizado em momento pós tarefa, quando há a possibilidade de abertura para temas transversais, trabalhando-se a interdisciplinaridade ou contrastes culturais, dependendo dos objetivos do professor e/ou do programa. 
Beeland Jr. (2002) aponta três modalidades de instrução de um determinado conteúdo que pode ser trabalhado durante uma tarefa. São elas: a visual, a oral e a cinestésica (ou tátil).

\section{Modalidades de instrução na tarefa:}

- Visual: aqui, temos por parte do professor, a possibilidade de utilização de um vídeo para trabalho com a escrita, imagens, animações e outros vídeos, de forma a contribuir para elevar o nível de interesse e motivação dos aprendentes.

- Oral: nesta, o professor pode utilizar o vídeo para tarefas que envolvam a língua falada, como: discursos e pronunciamentos, trabalho com pronúncia e reconhecimento de ritmo de fala e entoação, atividades musicais e reconhecimento de sons associados com outras semioses.

- Cinestésica: já neste caso, os aprendentes podem interagir entre si e com elementos da realidade (realia) na elaboração de vídeos, a partir de uma tarefa pré-estabelecida.

Em relação à terceira pergunta, que questiona como os recursos semióticos presentes nas mídias digitais selecionadas podem ser inseridos na realização das tarefas para o ensino-aprendizagem de PLE, frisamos que a ideia apresentada aqui é propor harmonização das unidades dos livros didáticos com a escolha dos vídeos online, de forma que a tarefa aplicada seja relevante, interessante e gere resultados em relação à construção de significados no contexto comunicativo.

A compreensão do contexto em que se está inserido não acontece simplesmente por meio de leituras de alguns textos por parte dos aprendentes de línguas, ou pelo uso aleatório de mídias digitais. Há muito mais complexidade envolvida nesse processo. Se indagações sobre a verdadeira intenção ideológica de textos multimodais não ocorrerem, o que se obtém é uma visão parcial da ideologia que permeia os discursos. 
Depois das exposições de reflexões iniciais, assim como conceitos pertinentes a este trabalho, temos em seguida a apresentação das bases teóricas norteadoras desta pesquisa. 


\section{CAPÍTULO 3}

\section{FUNDAMENTAÇÃO TEÓRICA}

Neste terceiro capítulo, apresentamos o arcabouço teórico que orienta esta pesquisa. As bases para esta dissertação consistem em proposições de pesquisadores cujas teorias direcionam o trabalho dos profissionais dedicados a ensinar aprendentes de Português como Língua Estrangeira. Em muitas ocasiões, além de outras atribuições, o trabalho do professor consiste em tentativas de "desestrangeirizar" 5 a língua alvo, os aspectos culturais, o que está nas entrelinhas do processo de ensino-aprendizagem e a construção de sentidos por parte de quem aprende. Assim, a importância de um capítulo de fundamentação teórica consiste, entre outros fatores, na delineação de uma escolha de teorias, entre tantas, para se fazer investigação científica. No caso do pesquisador em estudos relacionados a língua(gem), temos o desafio da busca por teorias adequadas às suas propostas.

Portanto, na seção 3.1, discorremos sobre a importância da pesquisa multimodal no ensino de Língua(s) Estrangeira(s), o que até o momento é algo novo e desafiador, já que temos poucos estudos que incluem este tópico em sua agenda. $\mathrm{Na}$ seção 3.2, apresentamos ideias relativas às possibilidades semióticas em Multimodalidade. Em 3.3, trazemos diferentes perspectivas para o ensino de PLE com a realização de trabalho baseado em tarefas. Na seção 3.4, apresentamos o letramento midiático e multiletramentos, que juntos estão entre as contribuições essenciais deste trabalho.

\footnotetext{
${ }^{5} \mathrm{O}$ termo "desestrangeirização" é empregado pelo professor Dr. José Carlos P. de Almeida Filho em suas aulas da disciplina de Aquisição de Segunda Língua, bem como na de Formação de Professores de Línguas do Programa de Pós Graduação em Linguística Aplicada da Universidade de Brasília - PGLA - UnB.
} 


\subsection{O LUGAR DA PESQUISA MULTIMODAL NO ENSINO DE LÍNGUA(GEM)}

Em sociedades da modernidade tardia (late modernity, como abordado por Chouliaraki e Fairclough em Discourse in Late Modernity: Rethinking Critical Discourse Analysis, 1999), boa parte das pessoas passa bastante tempo dos seus dias assistindo televisão, diante de telas de computadores ou celulares, lendo o que está presente na mídia impressa com uso de imagens, até mesmo - aprendizado passa pelo contato com livros didáticos permeados por apresentações sonoras e/ou visuais. A consequência disso é que estamos cada vez mais inseridos no letramento visual. Têm surgido, então, apontamentos no sentido de que devemos dar ênfase à modalidade visual durante aprendizagens, o que é mais condizente e oportuno em relação ao contexto atual. A Teoria da Multimodalidade vem ao encontro das pesquisas em ensino de LE propiciando elementos teóricos que possibilitem o entendimento do que seja letramento visual.

Em termos de estudos multimodais, é necessário considerar o estudo da linguagem com o propósito de obter mais clareza sobre as implicações de uso de diferentes modalidades em textos, leia-se aqui modalidades como referentes a diversas formas de realização da linguagem. Ao transferir isso para o âmbito do ensino, temos de considerar, ainda, que o texto ganha abrangência para além da palavra escrita. As paisagens semióticas da comunicação têm passado por importantes transformações, o que produz efeito na forma e nas características da escrita de textos, que, por sua vez, são autenticamente multimodais, nos quais coexistem mais de uma modalidade (sonora, imagética, gestual, etc.). Isso significa, na prática, que professores e alunos têm diante de si material de estudo que reflete as mudanças da sociedade contemporânea. Dessa feita, o material didático representa um recorte da realidade de uso da língua, que assumimos como sendo multimodal.

A importância da pesquisa multimodal nasce, assim, do entendimento dos textos como sendo formados por diferentes recursos semióticos, que compõem significado em conjunto com a língua escrita. Nessa ótica, direcionamos nossa discussão para o papel do vídeo online no ensino de Português do Brasil como 
Língua Estrangeira. Essa decisão é apoiada na ideia de Hodge e Kress (1988) sobre a reconstrução de uma semiótica que tenha como foco funções e usos sociais de diferentes estudos semióticos pelos produtores de signos. Nessa linha, nosso estudo é delineado com bases no reconhecimento de que a dimensão social é indispensável para análise de sistemas de significado.

A Multimodalidade, como base da pesquisa, traz como contribuição escopo para o estudo de modos específicos de comunicação diferentes da escrita, mas que tenham potencialidade de significação, como o visual e 0 sonoro. Aqui o objeto eleito, vídeos online, entra como amostra de que a dominação de linguagem escrita como meio de comunicação é, na verdade, uma falácia. Diferentes modalidades da língua coexistem para a representação e produção de significados, e a tarefa do pesquisador é reconhecer as potencialidades dos diferentes recursos semióticos empregados nas diferentes modalidades.

O ensino de língua estrangeira, desde sua origem, é permeado pelo uso de diferentes multimeios. Citamos como exemplo disso a abordagem audiolingual, em que o elemento sonoro é a base para a realização de muitas das tarefas. Em razão disso, o interesse pela real importância de cada recurso a ser empregado foi sendo desenvolvido ao longo de décadas. Porém, à medida que o foco na construção de sentidos e no significado ao invés da forma foi sendo privilegiado em abordagens mais comunicativas de ensino de LE, temos a presença de outras semioses nos ambientes de aprendizagem de línguas.

Ambientes de ensino-aprendizagem multimodais são permeados por textos que envolvem um jogo complexo de construção de significados (sejam escritos, imagéticos ou verbais), cores, elementos gráficos, sonoros, perspectivas de imagem, enquadramento, escolhas lexicais, que são importantes recursos semióticos na construção de diferentes discursos. Kress e van Leeuwen (2001, p. 24) compreendem discurso como "conhecimentos socialmente construídos de algum aspecto da realidade".

Combinando as diferentes modalidades em forma de texto, pode-se, então, construir o discurso de formas também diferentes. Tendo os textos 
multimodais como "produção de significados em múltiplas articulações" (KRESS E VAN LEEUWEN, 2001, p. 4), esses autores fazem referência à Linguística Sistêmico-Funcional, apontando os três domínios nos quais a questão do significado pode ser organizada: o design, a produção e a distribuição.

Em relação a design, trata-se não somente dos recursos semióticos, mas também, e principalmente, do uso que é feito desses. Todas as modalidades são combinadas, de forma que é possível ver organização do que será articulado. Como o discurso é realizado em contexto de determinada situação de comunicação, no design incluem-se, também, o hábito, a convenção, a tradição e a inovação. Uma possível alteração desses conhecimentos socialmente constituídos poderá ocorrer, mas somente por meio da interação social.

A produção pode ser entendida como a interação dos recursos materiais e o uso comunicativo do meio. Trabalho físico que pode ser feito por ser humano ou por máquina, que por sua vez venha a articular textos, organizando a expressão, o meio de execução do que foi elaborado no design. Assim, os órgãos do ser humano relacionados aos sentidos, responsáveis pelos diferentes canais sensoriais, então intimamente ligados ao meio de produção. Diferentes órgãos captam diferentes qualidades materiais.

Sobre a questão da distribuição, está diretamente ligada à maneira pela qual o produto é veiculado para o mercado. Um produto pode ter diferentes suportes: sites, jornais, revistas, televisão, outdoors, entre outras formas de veiculação. A participação no evento comunicativo é, ainda de acordo com Kress e van Leeuwen (2001), condicionada a "camadas" do formato de produção, que são os estratos linguísticos da semântica e a estrutura de participação.

Partimos da necessidade de encontrar parâmetros para a prática do docente em planejamentos de tarefas, sobretudo incluindo o uso de vídeos online e problematizamos sobre as potencialidades desse recurso, sempre com base em proposta de fundamentação teórica triangulada na Teoria da Multimodalidade, de Kress e van Leeuwen (1996); as Teorias de Ensino Baseado em Tarefas, com autores como Prabhu (1987), Richards e Rodgers (2001), 
Almeida Filho (2002) e Barbirato (2008), e no Letramento Midiático e Multiletramentos, com os autores Kellner (2008) e Beeland (2014).

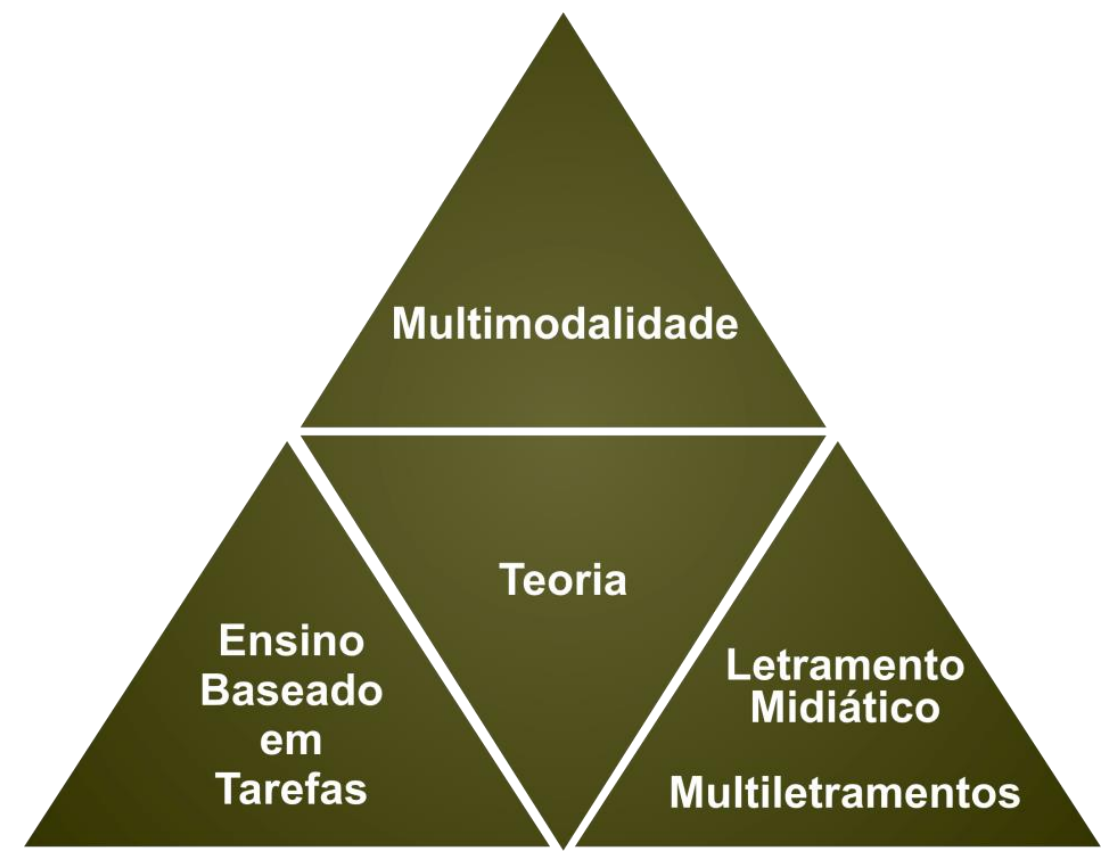

Figura 6 - Triangulação teórica entre Multimodalidade; Ensino Baseado em Tarefas; Letramento Midiático e Multiletramentos

Nas seções seguintes, traçamos breve panorama sobre como a triangulação teórica selecionada pode embasar a pesquisa aqui realizada.

\subsection{AS POSSIBILIDADES SEMIÓTICAS EM MULTIMODALIDADE}

Segundo Baldry e Thibault (2006, p. 1), diferentes tipos de textos multimodais e gêneros podem e devem ser analisados por meio de uma transcrição multimodal que possibilite abordagem mais adequada para a organização textual. Isso se deve ao fato de que, contextualizar diferentes níveis textuais significa na prática ligar noções extralinguísticas ao que é representado no texto. Nesse sentido, entendemos o vídeo online como este texto de 
abrangência extralinguística em contexto de movimento espacial e temporal, como a Internet.

A proposta de Kress e van Leeuwen (1996) com a Teoria da Semiótica Social cuja principal preocupação é o texto visual, analisando os textos multimodais em nova formulação, alcança a questão semiótica de forma mais abrangente. Assim, recorremos ao questionamento lançado por Kress e van Leeuwen (1996) sobre textos multimodais: "é possível confiar somente na língua, se desejamos entender a 'operação de poder' nos objetos que chamamos de 'textos'?". Como a teoria proposta por esses autores está inserida na investigação e na pesquisa social crítica, há mais um questionamento: como a multimodalidade textual é teorizada e pode ser aplicada pela pesquisa em Linguística Aplicada? Em relação à primeira indagação, é necessário que se entenda que a língua como meio de comunicação, sobretudo na modalidade escrita, figura apenas como um dos vários modos de representação no domínio público. Assim, a focalização somente na escrita não é suficiente se temos interesse e preocupação com a construção de significados advinda de várias semioses. Quanto à segunda questão, Kress e van Leeuwen (1996, p.12) explicam o seguinte em relação à aplicação da Semiótica em estudos de linguagem:

a análise da comunicação visual é, ou deveria ser, uma parte
importante das disciplinas críticas. (...) vemos imagens de
qualquer tipo como algo inteiramente dentro do prospecto da
ideologia, como meios - sempre - para o surgimento de
posições ideológicas, com todas as complexidades de tal
argumento. (...) procura mostrar como os discursos
aparentemente neutros e puramente informativos de jornais,
publicações do governo e ciência social, e assim por diante,
podem de fato resultar em atitudes ideológicas assim como
discursos mais explicitamente editoram e propagam, e como a
língua é usada para proporcionar status na interação social
contemporânea.

Consequentemente, a quantidade de informação tem aumentado na era do argumento visual, e precisamos estar preparados para ler várias semioses de maneira crítica e aprimorada, assim como proporcionar que os aprendentes de línguas também o façam, e tudo isso justifica a importância de trabalho estruturado em busca de conhecimentos que nos levem a prática multimodal, 
segundo a qual o sujeito é consciente das diferentes significações em diversas modalidades da língua.

$\mathrm{Na}$ aprendizagem de LE (Línguas Estrangeiras), o indivíduo estabelece contato com aspectos socioculturais da língua. Um dos pontos da nossa triangulação é o Ensino Baseado em Tarefas. Este movimento surgido nos anos 70/80, seguiu certos princípios, tais como: 1) a utilização de atividades envolvendo momentos de comunicação real; 2) a execução de tarefas que fossem significativas para o aprendiz [ou aprendente, como está aqui referido] e, em consequência, promovessem o aprendizado e 3) o uso de língua que fosse significativo para o aprendiz [aprendente] e sustentasse o processo de aprendizagem (RICHARDS E RODGERS, 2001).

Para fortalecer a questão do uso de vídeos online no trabalho com tarefas para ensino de PLE, apesar de estes conceitos não serem prioridade para esta pesquisa, citamos também conceitos presentes em hipóteses de Krashen (1985) como mera revisitação das bases da LA (Linguística Aplicada). Para este autor, a aquisição ocorre mais naturalmente se o aluno estiver exposto a mostras significativas da LE, que no caso desta pesquisa, são as possibilidades de construtos, criação de significados e interações culturais por parte dos aprendentes de língua a partir do contato e dos trabalhos com os vídeos.

Como uma das intenções centrais deste trabalho é revelar as potencialidades de vídeos online no ensino de português como LE, uma proposta de ensino baseado em tarefas se mostra bastante condizente, pois segundo Barbirato "a sala de aula poderá se tornar um contexto real e social, na qual os aprendizes (aqui aprendentes) reconhecerão no desenvolvimento das tarefas situações de vida real" (BARBIRATO, 2008).

Atualmente vemos, em passos lentos, articulação de diferentes modos semióticos utilizados na sociedade da modernidade tardia. Os ambientes de ensino-aprendizagem de LE ainda priorizam, de forma logocêntrica (com foco na palavra ou razão), a leitura do texto verbal em detrimento de todos os outros, o que aqui chamamos de leitura monomodal. Vale ressaltar que não se propõe aqui excluir ou minimizar o trabalho que é realizado com os textos verbais, mas realizar acoplamento com outros modos semióticos, possibilitando construção de significados com base na leitura das entrelinhas, tornando o indivíduo um 
leitor de textos verbais e imagéticos, melhor preparados para uma vivência comunicativa da LE.

Os autores Kress e Van Leeuwen (2001) tratam de maneira bastante aprofundada da tendência pelas práticas monomodais no mundo ocidental em diversas áreas e gêneros da escrita. À medida que outras semioses foram surgindo tanto na modalidade escrita da língua como em práticas de ensino, tendo a presença de novos layouts em livros didáticos, atividades de áudio complementares às de escrita, e também o uso de vídeos, esses mesmos autores afirmam que o começo de prática multimodal, significando quebra de paradigma no que diz respeito principalmente à modalidade escrita, não ocorreu de maneira brusca. O contato com diferentes semioses, cores, sons e representatividades não é suficiente. Há de se pensar sobre as potencialidades de tudo isso em consonância com a escrita.

Sobre o trabalho com vídeos em sala de aula, Morán $\left(1995\right.$, sic) ${ }^{6}$ esclarece-nos que o vídeo ajuda o professor, atrai os alunos, mas não modifica substancialmente a relação pedagógica. Este autor ainda diz que o vídeo, por significar descanso ao invés de "aula" para os alunos, modifica a postura e as expectativas em relação ao seu uso: atrair os alunos para os assuntos do planejamento pedagógico da aula.

Vídeo significa, também, de acordo com Morán (1995),

uma forma de contar multilinguística, de superposição de códigos e significações, predominantemente audiovisuais, mais próxima da sensibilidade e prática do homem urbano e ainda distante da linguagem educacional, por esta ser mais apoiada no discurso verbal-escrito.

Morán ainda acrescenta que o vídeo explora também, e basicamente, ver, visualizar, ter diante de nós as situações, as pessoas, os cenários, as cores, as relações espaciais (próximo-distante, alto-baixo, direita-esquerda, grande-

\footnotetext{
${ }^{6}$ http://www.revistas.usp.br/comueduc/article/viewFile/36131/38851
} 
pequeno, equilíbrio-desequilíbrio). Além disso, o vídeo desenvolve um ver entrecortado, com múltiplos recortes da realidade.

Ferraz (2011, p. 24) acrescenta que falar sobre monomodalidade no mundo atual não condiz com a realidade em que vivemos, sendo obrigatório em termos de ensino de língua(s) estrangeira(s) ultrapassar os limites da escrita. Assim, o vídeo como mídia figura como material multimodal pronto para uso, mas que depende da tomada de decisão docente para que seus diversos recursos semióticos sejam de fato empregados. Na perspectiva multimodal, materiais didáticos abrem espaço para diferentes construções de sentido, o que pode vislumbrar como saída para munir o professor de ferramentas que atendam à especificidade de sala de aula e de seu público-alvo.

Para Ferraz (2011, p. 45), sempre de acordo com a proposta multimodal, devemos entender que os efeitos de sentido devem ser trabalhados por meio de interfaces que incluam o ambiente digital, no qual hierarquias entre modalidades dependem muito mais de uma articulação combinatória consciente por parte do usuário do que somente da justaposição de modalidades, isso por consequência coloca o vídeo online em evidência no planejamento de tarefas para o ensino de PLE.

Na seção seguinte, passamos a tratar sobre como o trabalho com tarefas é hoje conceituado.

\subsection{O TRABALHO COM TAREFAS: DIFERENTES PERSPECTIVAS PARA O ENSINO DE PLE}

Trabalhar uma aula de língua estrangeira tendo como orientação o Ensino de Línguas por Tarefas envolve considerar a tarefa em si como um dos principais componentes. Barbirato (2008) explica que "a sala de aula poderá se tornar um contexto real e social, na qual os aprendizes [aprendentes] reconhecerão no desenvolvimento das tarefas situações de vida real". Almeida Filho (2005) também reforça as potencialidades da tarefa no ensino de língua estrangeira, dizendo que "as atividades comunicativas representam uma experiência diferenciada para o aluno (...), com atividades voltadas para a emissão de mensagem contextualizada". Este autor também sinaliza que o ensino baseado 
em tarefas "[viabiliza] em sala de aula um ensaio para a vivência do aluno, ajudando-o a opinar, tomar decisões, ser capaz de produzir e construir conhecimento", o que se encaixa com o que temos proposto até aqui, pois ao apoiarmos o uso de tarefas associadas a vídeos online, objetivamos que o aprendente possa lidar, de forma cada vez mais eficaz e reflexiva, com o fluxo de dados advindo dos ambientes digitais. Os autores Richards e Rodgers (2001, p. 228) sugerem que "as tarefas promovem processos de negociação, modificação, refraseamento/reformulação de frases (rephrasing) e experimentação, que estão no coração da aprendizagem de uma segunda língua".

Quando os aprendentes de línguas estrangeiras realizam tarefas, há foco importante no sentido, pois o que motiva a comunicação é alguma finalidade, que por sua vez deve ser o mais aproximado possível da vida real. Foster (1999, p. 69) nos esclarece que "ao engajar-se em atividades [mais] significativas, como resolução de problemas, discussões ou narrativas, o sistema de interlíngua do aprendiz é alongado e [ele] é encorajado a desenvolver-se".

Muitas vezes, mesmo professores bem preparados se deparam com certo distanciamento entre a realidade do ambiente de sala de aula e o que acontece no mundo lá fora. Assim, ao executar uma tarefa, os aprendentes envolvem-se em atividade de comunicação que reflete de perto o que se utiliza, em termos de uso da língua, o que acontece fora do ambiente de sala de aula. O aprendente se esforça para realizar um objetivo não necessariamente linguístico, utilizandose de meio linguístico. Para que isso possa ocorrer, é fundamental que se utilize de estruturas não normalmente priorizadas no ambiente de aprendizagem formal, como pessoas falando de forma espontânea e muitas vezes rápida, linguagem vaga, palavras abreviadas na modalidade escrita, e outras convenções que possam surgir.

Devemos chamar atenção ao fato de que, quando dizemos que no Ensino de Línguas por Tarefas o foco é no sentido, e não na forma, não há necessariamente desprezo pela segunda. A forma, na verdade, deixa de ser o foco principal, porém uma parte do objetivo geral, quando o aprendente alcança nível adequado de desdobramento na comunicação verbal. 
O contexto social em que a língua-alvo é usada é muito importante, pois o Ensino de Línguas por Tarefas procura proporcionar aos aprendentes o uso da língua a partir de contextos reais. A questão da variação da língua em determinados contextos também é priorizada, pois os aprendentes poderão verificar, assim, que a língua varia de acordo com contextos sociais.

Tendo como base Nunan (2004), podemos traçar algumas dicotomias sobre o Ensino Baseado em Tarefas em contraste com outras abordagens (cujo foco não seja o uso de tarefas):

\section{Ensino Baseado em Tarefas versus outros tipos de ensino:}

- $\quad$ Ênfase na aprendizagem comunicativa, com interação na língua-alvo, ao invés de foco na forma da língua e interação na língua do aprendente

- Seleção de conteúdos tendo como base as necessidades dos aprendentes, ao invés de um programa rígido, pré-estabelecido

- Utilização de textos autênticos nas situações de comunicação, ao invés de textos superficiais e de pouca aplicabilidade

- Aproveitamento da experiência pessoal dos alunos e seu conhecimento de mundo, ao invés de prática focada no professor e seus conhecimentos

- Foco não só na língua, mas também em todo o processo de aprendizagem/aquisição desta

- Relação entre a língua utilizada em aprendizagem na sala de aula e a língua utilizada fora de sala de aula

Quadro 2: sobre contraste do Ensino Baseado em Tarefas versus outras abordagens. 
Nunan (2004) ainda nos apresenta sete princípios básicos do Ensino

Baseado em Tarefas, quais sejam:

\section{Modalidades de instrução na tarefa:}

1. Scafolding (andaimes): segundo este princípio, não se espera, em princípio, que os alunos produzam na língua-alvo o que ainda não lhes foi apresentado. A oferta de material por parte do professor deve ser de acordo com a realidade do aluno. O professor deve saber quando remover o andaime, pois caso seja removido antes da hora, o uso autônomo da língua por parte dos alunos não será desenvolvido.

2. Dependência da tarefa: trata-se aqui de como a tarefa é explorada e construída a partir daquelas realizadas anteriormente. Deve-se trabalhar no sentido de conduzir o aprendente para a tarefa pedagógica final de uma sequência. $O$ trabalho receptivo demanda mais tempo do que o produtivo no início, o que mais tarde tende a mudar, fazendo com que o trabalho produtivo seja maior.

3. Reciclagem: reciclar a língua faz com que o aprendente aumente suas oportunidades de aprender. Baseando-se numa abordagem analítica para o ensino-aprendizagem, temos que este é um processo, pois é gradual e propriamente instável. Se há possibilidades de que o aprendente não conclua cem por cento do domínio na primeira vez, devemos reforçar que ele o encontrará um item linguístico particular, que por vezes deverão ser reintroduzidos ao anterior

4. Aprendizagem ativa: de acordo com este princípio, ao ensinarmos uma LE, devemos reservar a maior parte do tempo para oportunizar aos aprendentes usarem a língua-alvo, pois estes aprendem mais pelo uso ativo da língua em foco. Porém, devemos ressaltar que a realização do trabalho em si é por conta do aprendente, e o foco no professor deve ser na tarefa, e não em dominar o tempo todo da aula

5. Integração: para Nunan, os aprendentes devem ser capazes de fazer relações claras entre formas linguísticas, função comunicativa e significado semântico. O princípio da integração não tem como objetivo separar tais construtos, mas fazer com que tenham uma relação sistêmica, e leve o aprendente a, de forma mais intuitiva do que explícita, compreender que a língua nova tem forma, função e significado.

6. Reprodução para criação: de acordo com este princípio, a reprodução dos aprendentes deve ser sempre encorajada para que seja criativa, deixando abertos caminhos para o novo. Ao utilizar-se de tarefas diferenciadas, o professor deve propiciar que os aprendentes combinem elementos familiares a/em caminhos novos. Este princípio não privilegia apenas alunos avançados, mas também os de nível básico, desde que haja uma sequência apropriada.

7. Reflexão: em determinados momentos, oportunizar aos alunos que reflitam sobre o que estão aprendendo, como estão se sobressaindo, poderá leva-los a serem mais reflexivos, o que consequentemente fará com que saibam onde o foco da língua muda, o que pode torna-los mais participativos no processo de aprendizagem da língua-alvo. Para o ensino baseado em tarefas, aprender a aprender é um elemento reflexivo e tem afinidade com os objetivos comunicativos.

Quadro 3: sobre os 7 princípios básicos do Ensino Baseado em Tarefas 
Prabhu (1987) ressalta que há processos cognitivos nas tarefas, são eles: seleção, raciocínio, classificação, organização de informação e transformação da informação de uma forma de representação para outra. Assim, a realização da tarefa faz o aprendente progredir, e este processo de aprendizagem está intimamente ligado à ativação dos processos de aquisição de língua(gem).

De acordo com Willis e Willis (2001, p. 173-174) devemos excluir do conceito de tarefa aquela que os autores chamam de focalizada, ou metacognitiva, que são exercícios focalizando a forma linguística. Para eles são apenas exercícios de gramática. Já o conceito de tarefa que aqui corroboramos é o daquela tarefa cujo foco é no sentido, havendo, eventualmente, uma negociação por parte de professores e aprendentes no que diz respeito ao trabalho específico da estrutura ou forma da língua.

Alguns teóricos já propuseram importantes modelos de trabalho (Prabhu 1987; Skehan 1996; Willis 1996). Porém, o que esses modelos têm em comum são as três principais fases do trabalho com tarefas: o pré-tarefa, a tarefa em si ou ciclo da tarefa, como proposto por Willis (1996), e o pós-tarefa, momento em que Willis descreve como foco na linguagem. Faremos agora uma revisitação desses conceitos como forma de nos localizarmos em termos de inserção do vídeo em diferentes etapas da aula, e em momento posterior, tomá-las como guia de aplicação, ainda que, para tal, não utilizemos todos os conceitos.

Willis (1996) diz que no momento do pré-tarefa o professor introduz o tópico ao grupo, salienta palavras e expressões úteis, explica a tarefa. Os aprendentes podem escutar material de áudio ou assistirem vídeo(s) de outras pessoas fazendo uma tarefa similar. Assim, o pré-tarefa é o trabalho realizado por alunos e professores em várias atividades, antes de se iniciar a tarefa em si, o que muitas vezes ajuda no tempo de preparação por parte dos próprios alunos antes do início da tarefa. O segundo momento é a tarefa em si, ou ciclo da tarefa. Willis (1996) propõe que nesse momento, os aprendentes realizam a tarefa em pares ou em pequenos grupos. O professor monitora à distância. Os aprendentes se preparam para relatar ao grupo todo, de forma oral ou escrita, sobre como realizaram a tarefa, e depois alguns grupos apresentam o seu relato ao grupo maior, ou trocam relatos por escrito, comparando os resultados. Aqui a própria tarefa é a parte central das ações, momento de se aplicar as opções 
instrucionais, tais como gerenciar o tempo das atividades e constatar se os alunos sabem lidar com as ações sob pressão de tempo. O terceiro momento é o pós-tarefa, que Willis (1996) chama de foco na linguagem. Trata-se de momento de análise, no qual os aprendentes examinam e discutem questões específicas do texto, ou áudio, ou vídeo. Em seguida, há o momento da prática, o professor conduz à prática de novas palavras, frases ou padrões estabelecidos. De acordo com Ellis (1997) a única fase obrigatória do ensino baseado em tarefas é a da tarefa em si. No entanto, o pré-tarefa e o pós-tarefa são momentos cruciais para que se tenha certeza de que a tarefa está sendo bem conduzida e aplicada.

\subsection{LETRAMENTO MIDIÁTICO E MULTILETRAMENTOS}

Segundo Vieira (2007, p. 24) a comunicação atual é multissemiótica, aqui adotamos o termo multimodal apenas por uma questão didática, uma vez que este termo advém da teoria da Multimodalidade. A mesma autora ainda aponta que as mudanças no cenário da linguagem ensejaram alterações profundas nas formas de letramento, que assumem sentido mais amplo. Textualmente a autora afirma:

o letramento, por sua natureza social, revela as práticas de escrita e de leitura de determinado grupo social, sendo capaz, ao mesmo tempo, de mostrar as formas emergentes de letramento em dado contexto sociocultural. É possível falar agora em multiletramentos, como letramento computacional, o visual, o tecnológico, entre outros. (STREET, 1984, 1993, 1995 apud VIEIRA, 2007, p.24).

Apesar de o termo "letramento computacional" ser citado por Vieira, aqui adotamos o letramento midiático, por acreditarmos ser este mais adequado e abrangente em termos de ambiente online e off-line, uma vez que as fronteiras entre ambos não dependem mais, somente, do equipamento computacional, podendo citar, por exemplo, os celulares smartphones. Atualmente o termo letramento extrapola a noção de conhecimento formal da língua escrita, apesar 
de este ainda ser célebre na sociedade moderna. Anteriormente falamos brevemente sobre o letramento midiático. Porém, aqui enfatizamos que consideramos importante recuperar, a essa altura, outros aspectos dessa teoria, por entendermos que o desempenho competente em termos de conhecimentos linguísticos é hoje perpassado pela utilização consciente de recursos computacionais e tecnológicos, tanto por parte de docentes como de aprendentes.

Ao tomar como objeto de estudo uma mídia digital como o vídeo online, temos como prerrogativa a análise de novos paradigmas sobre letramento. Isso afeta a forma como a composição de textos articulados com imagens são unidos, trabalhados e apresentados em sala de aula de PLE. Distante de ter um papel passivo no processo de aprendizagem, o aprendente de língua estrangeira está em plena fase de desenvolvimento das habilidades de reconhecimento e uso de diferentes modalidades na língua-alvo. Assim, os professores que ainda não se preocupam em instrumentalizar os aprendentes de acordo com essa nova cultura multimodal podem incorrer no erro de manter suas aulas cunhadas na monomodalidade.

Assim, entendemos os multiletramentos como conhecimento social de diferentes formas de significação da linguagem, não de maneira isolada, mas construída em conjunto. A velha máxima de se trazer para sala de aula material autêntico que evidencie práticas cotidianas de uso linguístico não passa pelo simples exame ideológico do que aquilo pode ou não representar. Aqui vale lembrar que ter acesso a diferentes visões de mundo é sim uma prerrogativa para o campo do ensino de LE. Multiletrar significa, portanto, elaborar um plano pedagógico em que questões culturais que subsidiam o texto multimodal são levadas em conta de acordo com seu potencial de significação.

Toda mídia nova passa por uma fase de transição. O cinema em seus primórdios era simplesmente uma câmara registrando a encenação de uma peça (Paul, 2010, p. 121). Essa afirmação nos reporta ao entendimento de como é impactante o surgimento de uma nova mídia, e todas as mudanças advindas de seu uso. A interatividade hoje é entendida não somente como função de comunicação, mas como experiência de controle (ou não) do usuário sobre a ordem social. Como exposto no capítulo 1, o YouTube definiu novas regras em 
termos de interação, uma vez que abriu espaço para que o usuário da Internet tivesse voz e vez. Aqui recuperamos, portanto, dois momentos de mídia visual: o momento analógico (cinema) e o momento digital (vídeo online). Da mesma maneira como ocorreu essa transição off-line e online, devemos considerar a transição do letramento formal para o midiático e por consequência dos multiletramentos.

Paul (2010, p. 123) diz que

$\mathrm{O}$ ambiente digital permite ao narrador usar qualquer um ou todos esses tipos de mídia na apresentação de seus textos. Devemos examinar quatro aspectos diferentes no elemento mídia: configuração, tipo, ritmo e edição.

- A configuração diz respeito à combinação de mídias usadas por quem desenvolve o conteúdo. Textos, fotos, gráficos, áudio, vídeo e animação podem ser usados sozinhos ou combinados. São possíveis três diferentes configurações desses tipos de mídia numa narrativa online:

- Conteúdo de mídia individual é o desenvolvimento de uma narração por intermédio de apenas uma mídia: texto, vídeo e áudio são as formas de mídia típicas usadas online.

- Conteúdo de mídia múltipla inclui dois ou mais tipos de mídia no pacote da narrativa, tanto como peça principal quanto como partes do contexto. Esses elementos de mídia se apresentam juntos, mas estão separados. Por exemplo, você pode clicar para ver a apresentação de slides ou vídeo, clicar para ouvir um segmento de áudio e rolar a barra de rolagem para ler o texto.

- Narrativas em multimídia utilizam dois ou mais tipos de mídia (por exemplo, imagens, texto) interligados numa apresentação perfeitamente articulada

- O tipo identifica a mídia específica que está sendo usada: texto, gráfico, gráfico em movimento, desenho animado, foto, foto em 3D, foto panorâmica, web câmara, vídeo, vídeo em 3D, vídeo em 360 graus, áudio e vídeos com poder de imersão.

- Ritmo/Fluxo - considera se o tipo de mídia é ao vivo ou gravado. O conteúdo gravado é antigo. É assincrônico na exibição. O conteúdo ao vivo é exibido em tempo real. É sincrônico.

- Edição: tempo / espaço refere-se ao grau de alteração ou edição que o conteúdo tem de sofrer. O conteúdo que é apresentado em sua totalidade e não foi resumido ou reorganizado pelo responsável pelo conteúdo é exibido em tempo real. O conteúdo que foi resumido ou reorganizado de alguma forma pelo responsável pelo conteúdo é um conteúdo previamente editado. 
Acrescentamos neste espaço as características das mídias no propósito de deixar claro o grande número de elementos envolvidos na produção midiática e que, portanto, demandam do usuário diferentes estratégias para acessar os conteúdos nelas dispostos. Na prática, isso se refere aos chamados multiletramentos, que entre outros, englobam o formal e o midiático.

É nesse escopo que o vídeo online traz consigo novas práticas cotidianas de circulação da informação, e essas práticas podem impactar o próprio entendimento do que vem a ser uma aula de língua estrangeira, por exemplo. É nesse aspecto que pretendemos elucidar como a inserção dessas mídias digitais em unidades didáticas de PLE permitem ao aprendente outras maneiras de lidar com diversos conteúdos trabalhados em sala de aula.

No próximo capítulo, faremos abordagem da metodologia aplicada à coleta de dados, bem como análise dos documentos selecionados. 


\section{CAPÍTULO 4}

\section{DEFININDO A METODOLOGIA}

Este quarto capítulo se propõe à apresentação da metodologia de pesquisa adotada neste trabalho e às principais categorias de análise empregadas na investigação dos dados. Na seção 4.1, fazemos uma breve definição do que é uma pesquisa qualitativa e quais as suas vantagens para o trabalho em Multimodalidade. Na seção 4.2, apresentaremos as etapas metodológicas aqui adotadas. Em 4.3, veremos que as categorias analíticas terão papel crucial para a resolução do objeto de estudo na busca pelos dados. A apresentação das categorias analíticas utilizadas nesta investigação será o propósito da seção 4.4. E, finalizando, na seção 4.5, teceremos apresentação da proposta de análise dos documentos.

\subsection{A PESQUISA QUALITATIVA: VANTAGENS PARA O ESTUDO DE ANÁLISE DOCUMENTAL EM MULTIMODALIDADE}

Como parte central da discussão aqui apresentada, adotamos uma abordagem qualitativa do método, enfatizando não a quantificação ou descrição dos dados recolhidos, mas a importância das informações que podem ser geradas com base em olhar cuidadoso e crítico das fontes documentais. É necessário que possamos compreender ainda que, dependendo da área de pesquisa do investigador e dos interesses do estudo, documentos que podem ser desprezíveis para uns podem ocupar lugar central para outros.

Segundo Bravo (1991), são documentos todas as realizações produzidas pelo homem que se mostram como indícios de sua ação e que podem revelar suas ideias, opiniões e formas de atuar e viver. Nesta concepção, é possível apontar vários tipos de documentos: os escritos; os numéricos ou estatísticos; os de reprodução de som e imagem; e os documentos-objeto (BRAVO, 1991). 
Flick $(2004$, p. 27) fala da importância da pesquisa qualitativa para o trabalho textual. Ele afirma que a pesquisa com essa abordagem trabalha, sobretudo com textos, e que até mesmo os métodos de interpretação partem de tais textos. Podemos resumir algumas ideias desse autor dizendo que 0 processo de pesquisa qualitativa pode ser representado como espécie de trajetória que vem da teoria para o texto, e outra trajetória do texto voltando para a teoria. Assim, os textos são a base do trabalho interpretativo, bem como das inferências realizadas com documentos e dados empíricos, tendo a compreensão interpretativa dos textos como ponto de partida.

Sobre o trabalho realizado pelos pesquisadores que se utilizam da pesquisa qualitativa, no que se refere ao valor da interpretação e reinterpretação dos dados, Denzin \& Lincoln (2006, p. 23) afirmam que

os pesquisadores qualitativos ressaltam a natureza socialmente construída da realidade, a íntima relação entre o pesquisador e o que é estudado, e as limitações situacionais que influenciam a investigação. Esses pesquisadores enfatizam a natureza repleta de valores da investigação. Buscam soluções para as questões que realçam o modo como a experiência social é criada e adquire significado.

Assim, a pesquisa qualitativa emprega ênfase na interpretação e reinterpretação dos dados. Tais construtos são, de acordo com esta perspectiva, constituídos por textos. Finalmente, sinalizamos um dos papéis mais importantes da pesquisa qualitativa para o trabalho cujo foco é em significados ao invés de formas. A pesquisa qualitativa tem como principal objetivo fazer a interpretação de realidades sociais, ou seja, baseando-se em um corpus mais específico, sendo necessário percorrer um caminho que leva da teoria para a realidade social e desta de volta para a teoria, interpretando e reinterpretando. Como conclusão sobre a importância do método qualitativo para pesquisas em multimodalidade, temos em Ferraz (2005, p. 52) que:

Ao trabalhar com discursos multimodais [temos que nos atentar que] também há sentido em gestos, sons e imagens. Os textos imagéticos, por exemplo, apresentam sentidos velados na forma 
da construção ou da apresentação/disposição das imagens, fotos, desenhos, tabelas entre outras modalidades. O método qualitativo é o mais coerente para análise dos dados colhidos [para a investigação em multimodalidade].

Após apresentada a importância da pesquisa qualitativa para trabalhos sobre multimodalidade, seguiremos na próxima seção para a apresentação dos passos norteadores da nossa metodologia de trabalho.

\subsection{ETAPAS METODOLÓGICAS}

Neste trabalho, partimos de algumas das principais categorias analíticas propostas pela Teoria da Multimodalidade com vistas a justificar os modos como identidades são constituídas por meio da junção dos recursos semióticos em textos multimodais. A partir da análise de outros trabalhos com propósitos similares, percebemos que investigações discursivas com base na análise de vídeos, sobretudo os online, ainda são bastante recentes, o que dificulta a tentativa de seguimento de um percurso teórico-metodológico já préestabelecido, como é possível de se realizar em outras áreas que possuem uma gama maior de estudos, assim como pesquisadores atuantes na área. No entanto, apesar de identificada tal dificuldade, abrimos a possibilidade de trilharmos um caminho de certa forma autônomo, pois sabemos que para o desenvolvimento de uma ciência é necessária a busca por novos métodos, pressupostos teóricos e, principalmente, uma nova (re)visão a respeito dos objetos de pesquisa e das fronteiras da área de pesquisa.

Assim, o seguinte roteiro será obedecido: análise das categorias referentes à gramática visual; em seguida aplicação das categorias da Multimodalidade para o trabalho estruturado com os vídeos online.

Taylor e Badgan (1998, apud Ferraz, 2005, p. 53) afirmam que existem algumas etapas que uma pesquisa qualitativa deve seguir, como podemos ver na figura abaixo: 


\section{Etapas Metodológicas:}

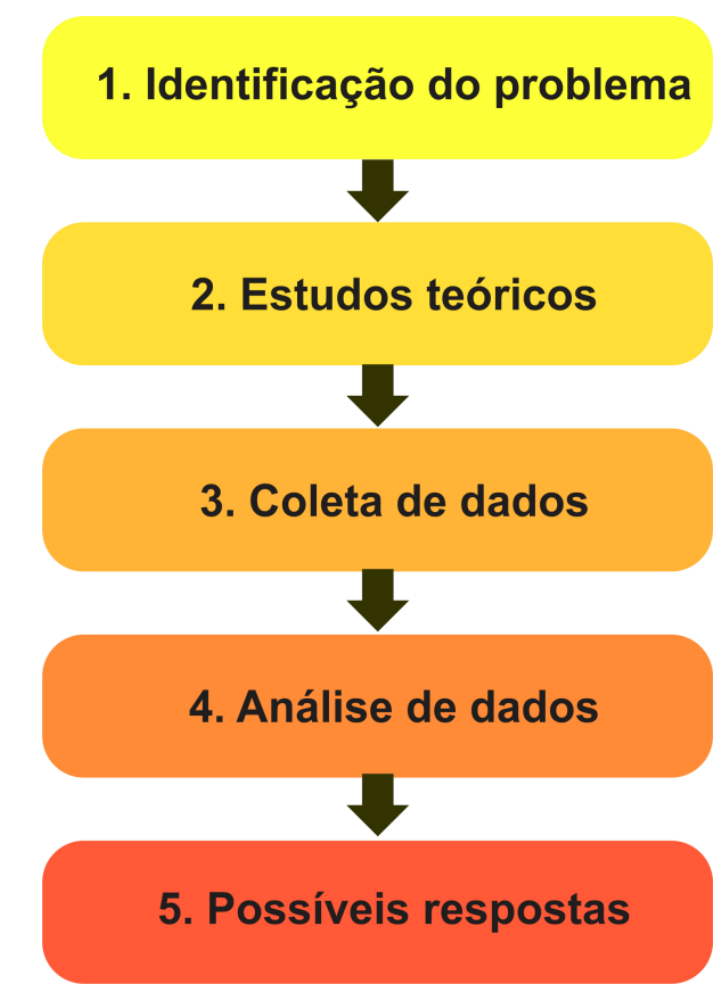

Figura 7: Etapas metodológicas segundo Ferraz (2005)

No entanto, devemos frisar aqui que as etapas descritas na figura acima, apesar de serem essenciais para a pesquisa qualitativa, não são únicas. Há outras etapas que podem ser incluídas, pois cada estudo tem seu delineamento próprio.

O início do trabalho é marcado pela definição do tema, do objeto a ser pesquisado. Então, a delimitação do tema deste presente trabalho partiu da percepção do potencial significativo dos vídeos online no trabalho realizado em sala de aula de LE, sobretudo quando há como proposta de ensino o trabalho realizado com tarefas, cujo foco é nos sentidos ao invés da forma, não se apoiando somente na modalidade escrita da língua, mas nas várias modalidades que permeiam o processo de ensino-aprendizagem. Assim, tivemos como direcionamento estudos da multimodalidade presente no trabalho estruturado 
entre unidades didáticas de livros e o uso de vídeos online, neste caso provenientes do YouTube.

Em relação à segunda etapa, os estudos teóricos, lembramos que estes se apresentam no segundo capítulo desta dissertação, ao selecionarmos as propostas teóricas às quais tivemos acesso. A relevância do papel da compreensão do objeto de pesquisa não se materializa como o ponto de partida para a pesquisa em si, mas como resultado de suposições prévias em relação aos dados selecionados. Isso coloca a percepção da pesquisa como elemento forte para uma abordagem qualitativa.

A terceira etapa, da coleta de dados, será detalhada no momento em que tratarmos da busca pelos dados, na seção 3.3 deste mesmo capítulo. Esta seção apresenta o momento em que entramos em contato com o corpus da pesquisa, o material que será analisado. A quarta etapa, a análise de dados, é exatamente a aplicação do recorte teórico. É importante frisar, neste ponto, que os dados determinam a teoria, e não o contrário. Muitas vezes a escolha da teoria a ser aplicada não é, necessariamente, a mais adequada. Flick (2009), argumenta que a pesquisa qualitativa é recente e ocorreu concomitantemente em várias áreas, e cada uma delas caracterizou-se, de alguma maneira, por um embasamento teórico próprio, por conceitos de realidade específicos e por seus próprios construtos metodológicos. A quinta e última etapa, sobre as possíveis respostas, será apresentada nas Considerações finais desta pesquisa. Seguiremos, então, à próxima seção, sobre a busca pelos dados.

\subsection{A BUSCA PELOS DADOS}

Para selecionar os dados, buscando um corpus de amostras que será coletado e analisado, entendemos que a natureza dos dados terá variações em relação à proposta, aos objetivos e questões de pesquisa. Porém, há alguns princípios gerais que podemos, de antemão, ter em mente.

A decisão sobre onde coletar amostras para compor um corpus se dá a partir do conhecimento e domínio sobre o que se está pesquisando. É necessário 
saber os processos de mudança que estão ocorrendo, identificando o que é útil para a pesquisa, e sabendo os caminhos para que se alcance tal problemática.

Os teóricos da Multimodalidade dependeriam, assim, de teorizações relevantes para este ramo da pesquisa de forma a tomar decisões sobre que amostras são tipicamente importantes e representativas de uma determinada prática. É necessário saber se um determinado corpus reflete de maneira adequada as várias facetas da prática, assim como as mudanças recorrentes, se adaptando a diferentes tipos de situação.

A geração dos dados originou-se a partir de experiências próprias deste pesquisador em relação a quais vídeos online poderiam conter maior potencial de utilização no trabalho com tarefas no ensino-aprendizagem de uma LE, sobretudo Português para aprendentes estrangeiros. Ao analisarmos livros didáticos para ensino de PLE, podemos perceber que há uma gama de possibilidades de trabalho com vídeos, seja para aquecimento/elemento motivador de um tema, ou na aplicação de uma tarefa em si, na qual os aprendentes podem realizar analogias, comparações com contrastes culturais, obtendo exposição de diversas modalidades presentes tanto no livro quanto nos vídeos apresentados. Tudo isso contribui, de alguma forma, para a reprodução da sociedade brasileira, e temos nesse recorte o aluno estrangeiro como seu principal leitor.

O início da coleta de dados se constituiu da busca, e posteriormente a seleção de documentação formal: livros didáticos cujas unidades apresentam textos multimodais, cuja temática fosse possível aliar-se ao trabalho com vídeos online, disponíveis no canal YouTube, o que "facilita" e "dá praticidade" ao trabalho do professor na preparação de sua aula em ambiente de sala. Nesse processo foram selecionadas unidades didáticas em dois livros de ensino de PLE, uma em cada livro, que são: Bem - Vindo! A Língua Portuguesa no Mundo da Comunicação, $8^{a}$ edição; e Novo Avenida Brasil 2, Curso básico de Português para Estrangeiros. A escolha desses dois livros se deve ao fato de serem amplamente adotados por escolas de línguas e professores particulares para 0 ensino-aprendizagem de PLE, tendo como seu público-alvo alunos estrangeiros. $\mathrm{Na}$ Universidade de Brasília, contamos com o NEPPE - Núcleo de Ensino e Pesquisa em Português para Estrangeiros, onde o livro Avenida Brasil é adotado. 
Já o livro Bem-vindo é bastante utilizado na Escola Americana em Brasília, por exemplo, refletindo o que está disponível atualmente para o professor dessa área de ensino. A partir das escolhas das unidades didáticas, procedemos às sessões de visionamento dos vídeos online no YouTube. De acordo com definições sobre trabalho estruturado com vídeos (como podemos encontrar no site http://www.ciberduvidas.com/pergunta.php?id=21979), há diferença entre visionamento, ou visionação (de visionar) em relação a visualização. Visionamento corresponde à ação de ver (um filme, um vídeo) do ponto de vista técnico, para algum tipo de problematização ou sistematização, que é o caso da nossa pesquisa. Já visualização (de visualizar) corresponde à apresentação de informação através do monitor (de televisão, computador, smartphone), e assume, também, o sentido geral do ato de ver. As sessões de visionamento tomaram como base as potencialidades multimodais para utilização dos vídeos em tarefas para o ensino de PLE.

Em princípio, pensamos na escolha de mais unidades didáticas, assim como mais vídeos. Porém, percebemos que tantas unidades e vídeos quantos forem selecionados não mudariam a essência do trabalho do professor. A forma de trabalhar a Multimodalidade, as semioses presentes nos livros e nos vídeos, não será determinada de forma quantitativa, mas sim qualitativa, em relação à própria filosofia de trabalho do professor. E o que se apresenta aqui são propostas para trabalho multimodal que podem ser aplicadas a unidades didáticas e vídeos diversos, independentemente do seu conteúdo. O que importa aqui são os construtos para que se possibilite trabalho mais condizente com as especificidades do mundo multimodal dentro de sala de aula, com elementos advindos da digitalização dos meios de ensino.

Seguimos, então, às categorias analíticas para a análise das modalidades envolvidas nesse processo de ensino-aprendizagem. 


\subsection{AS CATEGORIAS ANALÍTICAS}

Esta seção visa a apresentação de definição das categorias analíticas que serão utilizadas nesta pesquisa. Como seguiremos, aqui, as diretrizes oferecidas pela Teoria da Multimodalidade como proposta metodológica de análise, faremos uma breve exposição das categorias e procederemos então às análises documentais e às considerações finais.

\subsubsection{Categorias da Gramática Visual}

Para os autores Kress \& Van Leeuwen (2006), A Gramática Visual se apresenta tanto como um método quanto uma teoria. Seu propósito é a investigação sobre de que forma os recursos semióticos se combinam para constituir significados. Em princípio, tal teoria objetivou analisar, principalmente, imagens estáticas, sendo ainda hoje considerada uma teoria nova, que é pouco aplicada na análise de textos constituídos por imagens em movimento, como é o caso dos vídeos online que encontramos no YouTube para esta proposta de análise. Nas próximas seções apresentaremos as categorias analíticas da Gramática Visual eleitas para aplicação nesta pesquisa.

\subsubsection{Participantes}

Os autores Kress \& van Leeuwen (2006) utilizam o termo "participantes" visando designar os elementos presentes em um texto multimodal. Os participantes podem ser chamados de 'volumes' ou 'massas' com diferentes 'pesos' e influenciados por diferentes forças de movimento (KRESS \& Van LEEUWEN, 2006, p.49). Tais denominações dadas aos participantes advêm do fato de que eles podem ser constituídos, por exemplo, por meio de diferentes tamanhos, formas e cores, o que confere aos participantes valores distintos em um texto multimodal, especialmente numa composição visual. No que diz respeito aos participantes, Kress \& Van Leeuwen dividem o termo em dois grupos: 
- Participantes representados: são aqueles que constituem o objeto da comunicação, isto é, os participantes inseridos em um texto multimodal por meio dos recursos semióticos.

- Participantes interativos: são aqueles para os quais a mensagem se dirige, isto é, são participantes da interação que estão fora do texto multimodal. Ao leitor de textos multimodais, especialmente os imagéticos, os autores deram o nome de viewer.

A análise dos dados vai lançar mão dos dois grupos de participantes, já que ambos constituem objeto de preocupação dos produtores de textos multimodais e seu emprego acarreta a defesa de discursos e ideologias diversas. Os participantes representados são aqueles presentes nos textos multimodais dos dois livros aqui analisados, assim como os presentes nos vídeos online que escolhemos para compor esta pesquisa. Os participantes interativos são aqueles para os quais os textos multimodais das unidades dos livros didáticos se dirigem. Também, são participantes interativos os que potencialmente assistirão aos vídeos, podendo ser qualquer internauta, ou quando o vídeo for transmitido no momento da aula, os aprendentes. Os viewers são, especificamente neste caso, os aprendentes, nos momentos de aplicação das tarefas em sala de aula, e os professores, nas seções de visionamento para escolha do vídeo e ao transmitirem aos aprendentes.

\subsubsection{O ponto de vista dos viewers}

Temos como categoria fundamental para as análises deste trabalho a relação estabelecida entre os participantes da imagem e seus viewers, já que ao realizar a análise desse processo, podemos compreender e identificar os recursos semióticos empregados pelos produtores de textos multimodais e seu escopo no mundo. Acerca desse tema, Kress, Leite-Garcia \& van Leeuwen (1997) defendem a tese de que:

A indicação do valor social pode ser verificada pelo tamanho de um elemento representado, ou pela distância de que está do viewer. a relação com a postura pode ser compreendida pela 
posição lateral do viewer em relação ao elemento (se está de frente, de lado, ou na margem). As relações de poder podem ser identificadas pela posição vertical do viewer com o elemento: se o elemento for mais poderoso, teremos que olhar para cima; se nós somos mais poderosos, olhamos para baixo; e assim por diante. Formas 'factuais' podem ser codificados por tipos de realismo, como em relação a um padrão do que devemos dizer e que modo de representação é o mais realista (provavelmente uma forma surrealista) do realismo cotidiano.

Ao constatarmos a forma pela qual os viewers se relacionam com a imagem, a partir dos pressupostos dos autores apresentados acima, reforçamos, então, um dos principais alicerces da Teoria da Multimodalidade: a forma como os produtores de textos multimodais organizam os recursos semióticos tem como objetivo, ainda que implicitamente, submetê-los aos seus interesses.

\subsubsection{Representações narrativas}

A partir do momento em que temos os participantes ligados a vetores, que funcionam na Gramática Visual de forma análoga aos grupos verbais que por sua vez apresentam ações na linguagem verbal, Kress \& Van Leeuwen designam o processo visual como narrativo. Os processos narrativos estão subdivididos em vários grupos conforme o tipo de participante envolvido, o número de participantes e o tipo de vetor ligado ao(s) participante(s) representado(s). Assim, apresentamos a seguir os tipos de processos narrativos que serão empregados nesta investigação.

\section{a) Processo de ação}

Afirma-se que um processo de ação ocorre na Gramática Visual quando um vetor se origina de um participante representado que costuma se destacar na imagem devido a saliência, tamanho, lugar na composição, cor, contraste com o segundo plano. Nesse tipo de processo, quando as imagens apresentam apenas um participante ligado a um vetor, tem-se uma estrutura visual não transitiva. Nessa estrutura, esse participante costuma ser o ator, que é o participante ativo de onde advém o vetor da composição visual da ação; mas também pode ser 0 alvo, participante passivo para 0 qual 0 vetor está 
direcionado. Dessa forma, a representação narrativa não transitiva é equivalente aos verbos intransitivos na linguagem. Na Gramática Visual, quando um processo narrativo possui dois participantes ligados por um vetor, um é o ator, o outro é o alvo; constituindo, portanto, uma estrutura visual transitiva semelhante à estrutura argumental dos verbos transitivos na linguagem.

As estruturas visuais transitivas dos processos narrativos são divididas em dois grupos: unidirecionais e bidirecionais. Nas unidirecionais, um vetor conecta um ator a um alvo. Já nas bidirecionais, os participantes, ligados por apenas um vetor bidirecional, atuam simultaneamente com o papel de ator e de alvo da estrutura visual transitiva. Caso haja dois vetores unidirecionais que partam de cada um dos participantes representados, classificam-se as ações como sequenciais e os participantes como interactors. Essa configuração visual é recorrente em imagens em que sejam apresentadas ações recíprocas entre os participantes representados.

\section{b) Processo reacional}

O processo reacional ocorre quando um vetor é constituído por uma linha que advém do olhar de um participante representado, que é chamado de reacter. Esse tipo de participante, que costuma ser humano, deve ser uma criatura com olhos visíveis e capaz de produzir expressões faciais. Assim como os processos de ação, os processos reacionais podem ser transitivos ou não transitivos. Caso o reacter presencie outra representação narrativa num processo reacional, teremos uma estrutura visual transitiva. Caso esteja presente apenas o reacter, teremos apenas uma estrutura visual não transitiva.

\section{c) Processo verbal}

Classifica-se como processo verbal o processo narrativo que apresenta um participante representado expressando o seu pensamento por meio de um enunciado verbal, como a fala de um personagem de histórias em quadrinhos por meio de um balão ou manifestantes por meio de faixas. Considera-se também como processo verbal a expressão de um enunciado por meio de 
mensagens presentes em cartazes que são segurados ou estão próximos a participantes representados. Esse tipo de processo empregado visualmente tem a propriedade de possibilitar a ocorrência concomitante de significados diversos expressos por meio da fala e da escrita.

\subsubsection{Representações conceituais}

Nesse tipo de representação, os participantes são representados no que diz respeito a seus atributos e características mais gerais. Dessa forma, os participantes envolvidos nesse tipo de processo não praticam ações, ou seja, haverá uma incidência muito menor de vetores nesse tipo do que em representações narrativas. Nas representações conceituais, há dois tipos de processos: classificacionais e analíticos.

\section{a) Processos classificacionais}

Os participantes são classificados conforme o tipo de relação que estabelecem entre si. De um modo geral, um ou mais participantes atuam como subordinados em relação a pelo menos um participante principal que é classificado como superordenado. Nesse tipo de estrutura visual, o papel dos participantes costuma ser definido com base no contraste observado na relação estabelecida entre os seus atributos.

\section{b) Processos analíticos}

Os participantes se relacionam por meio da relação entre a parte e o todo na estrutura visual. Há dois tipos de participantes nesse tipo de processo: carrier (portador ou o todo) e os atributos possessivos relacionados. Portanto, há uma relação indissociável entre diversas partes da imagem na constituição do todo, isto é, os atributos vão conferir uma significação mais específica do carrier. 


\subsubsection{A composição espacial do significado}

Uma vez que a forma pela qual os elementos de uma composição visual se combinam influencia substancialmente a constituição de significados numa imagem, Kress \& van Leeuwen (2006) consideram a composição espacial do significado como uma categoria de análise relevante para a Gramática Visual.

Nessa categoria, destaca-se a atuação de três sistemas:

a) Valor da informação: diz respeito à localização de cada elemento (participantes, sintagmas que se relacionam entre si e com o leitor) na estrutura visual, se está à esquerda ou à direita, na margem ou no centro, no alto ou embaixo.

b) Saliência: diz respeito à relevância que os elementos assumem na imagem devido a diferentes graus de atenção relacionados às suas características numa determinada estrutura visual. Tal importância pode ser obtida por meio do uso de diferentes graus de intensidade das cores ou de imagens em preto e branco, do tamanho de um elemento em relação aos demais ou mesmo pela sobreposição de um elemento em relação aos outros.

c) Framing (enquadramento): a presença ou a ausência de molduras é realizada por elementos que criam linhas divisórias, desconectam ou conectam elementos da imagem, compondo ou significando de forma conjunta ou não.

Os autores ressaltam que a importância desses três sistemas não está restrita à análise de textos visuais simples, mas também a textos que combinem diversas modalidades em sua composição e que podem ser veiculados em vários meios, como a tela do computador ou da televisão. Kress e van Leeuwen (1996, p. 52) afirmam que:

O emolduramento visual é um problema de grau: elementos da composição podem ser fraca ou fortemente emoldurados. $O$ elemento estará fortemente emoldurado quando caracterizar-se como unidade separada de informação. Os membros de um grupo, por exemplo, podem estar apresentados como um grupo 
de pessoas em uma foto (v.g. fotos de escola, família, empregados em uma companhia etc.) ou em uma colagem de fotos individuais, marcadas por linhas de moldura e/ou espaços vazios entre elas (como exemplos fotos de diretores em uma revista da empresa). A ausência de moldura marca a identidade do grupo, sua presença significa individualidade e diferenciação. Quanto mais os elementos de uma composição espacial estiverem coesivos mais serão apresentados como uma unidade de informação, formando uma unidade.

\subsubsection{A projeção e a saliência}

Esta categoria, como seu nome já induz, diz respeito ao destaque que um elemento pode ter em um texto multimodal devido ao seu tamanho, forma, prolongamento de um som, contraste de cores, perspectiva, intensidade. Em suma, trata-se da relação entre os fatores capazes de dar destaque a um elemento em relação aos demais. O uso dessa categoria contribui para que haja uma hierarquia entre os elementos que constituem um texto multimodal. Uma observação importante é que em um texto multimodal podem ser atribuídos diferentes graus de projeção/saliência para os elementos que o constituem. Com isso, a saliência é uma categoria multiforme que pode diferenciar vários traços para construção de significados, por meio do uso dos recursos semióticos.

\subsection{PROPOSTA DE ANÁLISE}

Tendo como base a metodologia apresentada até este ponto, investigarei como a junção dos recursos semióticos corrobora para a constituição de significados, nos vídeos online escolhidos no YouTube para a proposta de realização de tarefas no ensino de PLE com base em unidades didáticas dos dois livros selecionados. A escolha desses vídeos como corpus pautou-se em como seriam aplicáveis em temas de unidades didáticas de livros de PLE, como forma de ampliarem possibilidades para trabalho com problematizações culturais, para exposição de ponto de vista ideológico, servindo de ligação entre tópicos universais e já familiarizados com tarefas já propostas nos livros didáticos ou pelo professor. Ademais, esses vídeos são exemplos significativos de textos multimodais, advindos de mídias de massa, e que interessam à Teoria da 
Multimodalidade pela forma como articulam diversos recursos semióticos para constituir significados. A fim de deixar mais clara a compreensão desta pesquisa, analisaremos inicialmente as categorias propostas por Kress \& Van Leeuwen, em seguida teremos alguns pressupostos do Ensino Baseado em Tarefas. Por fim, discutiremos aspectos ligados às potencialidades dos vídeos selecionados e o trabalho estruturado na realização das tarefas. Na próxima seção, iniciaremos a análise desses textos multimodais a fim de colaborar com a reflexão crítica sobre o desenvolvimento do trabalho com vídeos online associados a tarefas em livros didáticos no ensino-aprendizagem de PLE. 


\section{CAPÍTULO 5}

\section{ANÁLISE DOS DADOS}

Neste quinto capítulo, com base nas reflexões discutidas anteriormente e por meio dos pressupostos teóricos da Teoria da Multimodalidade, do Ensino Baseado em Tarefas e dos Letramentos Midiáticos e Multiletramentos, procederemos à análise dos dados. Para elucidar melhor os critérios utilizados neste trabalho, apresentamos a seguir o corpus de pesquisa, buscando sempre esclarecer quais fatores nos levaram a considerar que os elementos constitutivos das multimodalidades presentes nos livros didáticos e nos vídeos selecionados têm potencialidade para o trabalho em sala de aula de PLE. Na seção 5.1 apresentamos a escolha do corpus, as unidades em dois livros de ensino de PLE; e em 5.2, apresentamos a escolha dos três vídeos online do YouTube seguidas das análises à luz das teorias selecionadas, além de outras considerações.

\subsection{ESCOLHA DO CORPUS: AS UNIDADES DIDÁTICAS EM DOIS LIVROS DE ENSINO DE PLE}

Nesta seção, apresentamos as partes que constituem as duas unidades didáticas escolhidas em cada livro de ensino de PLE. Primeiramente, descreveremos a parte física e os conteúdos da unidade do livro 1) "Bem Vindo: A Língua Portuguesa no Mundo da Comunicação", e em seguida faremos o mesmo trabalho com o livro 2) "Novo Avenida Brasil 2: Curso Básico de Português para Estrangeiros". Consideramos este expediente de suma importância, pois na abordagem qualitativa a relevância dos dados como amostra representativa é um dos requisitos para que a pesquisa seja um trabalho fidedigno. Nesta parte destacamos também a importância de abordagem que tenha como objetivo o letramento midiático, uma vez que no âmbito do ensino de LE o objetivo é preparar o aprendente para o uso social da língua alvo. 


\subsubsection{Livro Bem-Vindo!: A Língua Portuguesa no Mundo da Comunicação}

Para o trabalho com este livro, escolhemos a unidade 18, intitulada "Saindo de Casa", que se inicia na página 171 e termina na 180. Esta unidade se subdivide em 5 partes: a primeira tem o título "curiosidades", com dois textos sobre os países do continente africano Angola e Moçambique; a segunda é "gente e cultura brasileira", trazendo definições do que seriam o mulato, o pantaneiro, o seringueiro, o caiçara, o jangadeiro e o mestiço oriental; a terceira tem o título "enfoque", e traz explicações gramaticais sobre o item regência verbal; a quarta tem como título "psiu", e apresenta informações sobre bagagem, itens para viagem, camping, praia, cuidados com o carro, telefones úteis e artigos para pesca; a quinta e última parte tem o título de "amplie seu vocabulário", e apresenta um texto intitulado "Viajar com eles? Pode ser ótimo", sobre viajar em família.

Para a escolha das unidades de cada livro, primeiramente acreditávamos que seria possível fazê-la de forma aleatória, já que o objetivo aqui seria privilegiar os vídeos online para a escolha de trabalho multimodal, entretanto, ao analisarmos as unidades didáticas, pudemos perceber que antes de pensar as mídias digitais, seria mais profícuo partir do LD que já é adotado em escolas de português para estrangeiros e desses livros, selecionar atividades dentro das unidades que poderiam ser melhor aproveitadas com trabalho com vídeos.

Outro critério de seleção das unidades em cada LD foi a própria temática proposta que, algo que naturalmente poderia suscitar debates, os quais acrescidos de vídeos correlacionados resultariam no desenvolvimento metodológico mais sistematizado e condizente com o que se espera de letramento midiático. Não se trata aqui de afirmar que há unidades didáticas que não podem ser trabalhadas com vídeos, mas é fato que para alguns temas é mais profícuo contar com vídeos como ferramentas de trabalho em sala de aula. Na seção sobre a escolha dos vídeos, citaremos o que Morán (1995, p. 29) fala sobre usos inadequados [de vídeos] em sala de aula, com o intuito de promover um contraste entre $o$ trabalho multimodal aqui proposto e uma postura nãosistematizada, comumente observada no uso dessa ferramenta. 
Ao analisarmos as unidades dos dois livros didáticos de ensino de PLE aqui citados, percebemos que há grande preocupação de ambos os autores com questões de cultura e de costumes brasileiros. Ora, se partirmos da ideia de que aprender uma língua estrangeira é, também, torná-la cada vez menos estrangeira, em um processo de "desestrangeirização", logo devemos pressupor que esse caminho traçado pelos livros didáticos aqui analisados é viável, já que não separamos língua e cultura.

A unidade 18 do livro "Bem-Vindo!" começa com textos com curiosidades sobre Angola e Moçambique. Apenas para ilustrar a composição multimodal empregada ao longo de toda a unidade, destacamos nesta parte como esta composição se faz presente por meio da junção entre textos verbais e imagéticos, no caso, as descrições seguidas dos mapas de dois países africanos. 


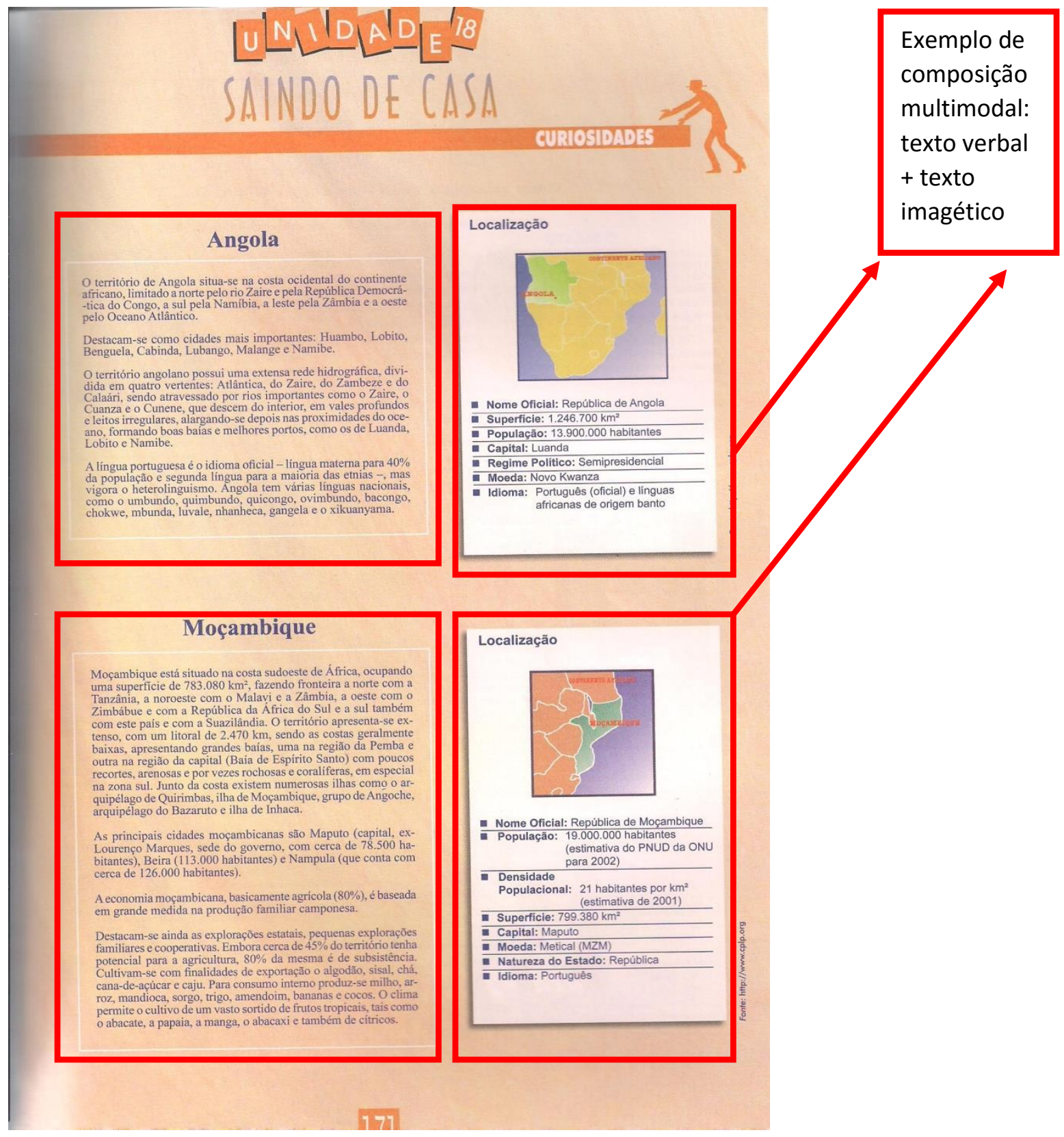

Figura 8: primeira página da unidade 18 do livro Bem-Vindo.

Em seguida temos uma seção sobre "Gente e cultura brasileira". Aqui temos lado a lado texto verbal e imagético, com definições sobre personagens típicos entre o povo brasileiro. Na página 173, inicia-se um tópico que é trabalhado nesta unidade até o seu final, questões relacionadas a viagem (bagagens, itens para viagem, camping, praia, cuidados com o carro, telefones úteis, artigos para pesca e no final um texto sobre viajar com os filhos). 
Na página 176, temos o item de número 7 , que traz dois folhetos informativos e publicitários. Neste item, os alunos devem observar os dois folhetos, perceber que eles têm em comum o tempo verbal "imperativo", e discutir sobre o porquê de tal uso gramatical. Os alunos devem, então, criar um folheto informativo para uma agência de viagens do seu país, destacando a sua beleza e cultura de forma atraente, convidativa e convincente. Os alunos devem usar o imperativo e criar um título para o folheto. Apesar de o livro não trazer nem citar nenhum vídeo relacionado a esta tarefa, é exatamente aqui que percebemos potencial para uso de vídeo online, pois identificamos no site YouTube certa facilidade em encontrar vídeos que servem sobre guia de viagens. Então, sugerimos como warm up (aquecimento) para esta tarefa, na contramão do que Morán (1995) chama de "vídeo tapa-buraco" (esse tópico está melhor desenvolvido na seção seguinte, por ora, cabe apenas uma alusão), que os alunos assistam ao vídeo, de forma que seja um momento de introdução do tópico, gerando entusiasmo por parte dos aprendentes, com mais motivação e insumos para realização da tarefa.

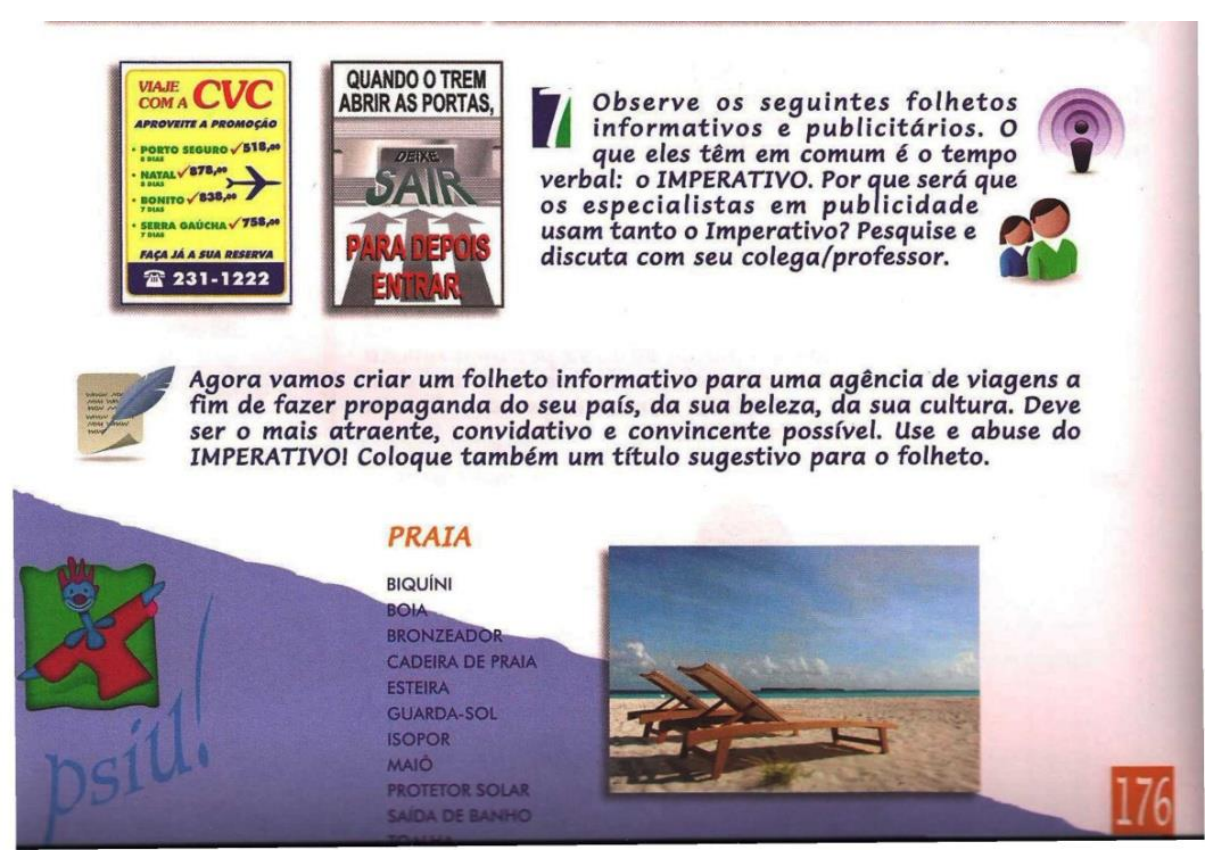

Figura 9: sexta página da unidade 18 do livro Bem-Vindo! 
Em seguida, faremos a mesma apresentação da unidade didática do livro Avenida Brasil 2, destacando suas características estruturais e de conteúdo, além da atividade potencial para uso de vídeo online.

\subsubsection{Livro Avenida Brasil 2: Curso Básico de Português para Estrangeiros}

Neste livro, escolhemos para análise a unidade de número 6 , intitulada "De norte a sul". A escolha desta unidade seguiu os mesmos critérios da escolha anterior, pois são temas em torno da representação do brasileiro, trazendo situações de estudos culturais, ainda, na mesma linha de análise, ressaltamos a importância de "desestrangeirizar" a língua alvo, o que permeia o processo de ensino-aprendizagem de uma LE.

No sumário, o livro subdivide suas lições em três partes: temas, comunicação e gramática. Para esta unidade escolhida, o tema é: as regiões do brasil, estereótipos, influências na cultura brasileira e tradições. A parte de comunicação objetiva caracterizar, descrever algo; comparar; expressar simpatia, antipatia. Na parte de gramática, está um tópico verbal: voz passiva com ser; voz passiva com -se; particípios duplos. Pronomes indefinidos: todo/a, todos os/todas as, tudo, cada.

Em princípio há bastante uso de imagens, seguidas de textos verbais, o que levaria os alunos a uma associação multimodal entre imagem e texto. Aqui cabe uma ressalva: para que imagem e texto verbal sejam de fato complementares, é necessário, antes de tudo, atividades que promovam a leitura multimodal, assim, ter imagens mescladas a textos verbais não garante um trabalho que leve ao letramento midiático. Dessa forma, é que a escolha temática das duas unidades aqui analisadas se justifica no que tange ao tratamento de estereótipos. Quaisquer imagens e textos verbais apresentados dentro desse tema, se não forem bem trabalhados, podem reforçar no aprendente ideias préconcebidas sobre a realidade brasileira, sua história e sua gente.

Posteriormente ao texto verbal, há um mapa do Brasil, com descrições de suas regiões em relação a número de habitantes, PIB (Produto Interno Bruto), atividades econômicas, indústria, agropecuária e extrativismo. Para esta seção, há exercícios de interpretação textual e uma atividade de compreensão auditiva 
na forma de diálogo, para que os alunos ouçam e leiam, e em seguida, discutam com o colega as mesmas questões do diálogo, mas sobre o país respectivo do aluno.

$\mathrm{Na}$ página 58, inicia-se discussão sobre estereótipos. Há algumas descrições de pessoas originárias de determinadas regiões brasileiras, assim como uma charge humorística sobre o tema. Aqui, os alunos devem realizar atividade para caracterizar, descrever algo; comparar; expressar simpatia, antipatia, como já citado no sumário da unidade. O livro não apresenta nenhuma atividade com o uso de vídeos, nem indica algum vídeo da Internet. Como dito anteriormente, esta temática sobre estereótipos é um divisor de águas, pois trabalha com diferenças culturais dentro de um mesmo contexto cultural, no caso, o brasileiro. Por esse motivo, consideramos que a inserção do vídeo online do YouTube possibilita ao docente outras maneiras de abordar o tema, considerando postura mais ativa dos alunos, que seriam levados a debater a realidade que lhes é apresentada. Essa afirmação baseia-se no fato de que utilizar o canal YouTube é prática discursiva comum dos alunos, que estão inseridos no mundo digital, o que pode e deve ser explorado na prática escolar cotidiana. É necessário ressaltar, neste segundo momento, ao contrário do trabalho anterior, que o vídeo não será warm up (aquecimento) para a tarefa, mas um recurso para o pós-tarefa, que tratará de reflexão a respeito de estereótipos, podendo haver espaço para que cada aluno diga como este aspecto é abordado em seus respectivos países, discutindo questões específicas do exercício proposto no livro didático, assim como novas palavras, frases e expressões presentes tanto nos vídeos quando na lição do livro.

Neste momento, retomamos um dos objetivos da pesquisa, que é refletir sobre as etapas de uma tarefa (o pré-tarefa, a tarefa em si e o pós-tarefa). Já fizemos a inserção de vídeos no pré-tarefa, como warm up, e no pós-tarefa como fixação e foco na linguagem. Na contramão sobre o que Morán (1995) fala sobre o "vídeo-enrolação" (o que será melhor explicitado na próxima seção), o conteúdo dos dois vídeos para trabalho com o livro Avenida Brasil 2 tem consonância com o debate sobre mitos e verdades acerca do brasileiro.

Posteriormente, a lição 6 do livro Avenida Brasil 2 traz explicações gramaticais sobre voz passiva, pronomes indefinidos, e em seguida conclui com 
algumas questões sobre a cultura brasileira e suas influências (língua, culinária, religião, dia a dia e música). A partir da página 63 , inicia-se o tema culinária, com texto verbal e algumas imagens de alimentos utilizados no Brasil. Há um texto sobre o bumba meu boi, com imagem da tradição ao centro do texto verbal. Nas páginas 65 e 66, retomam o assunto comidas, com atividades de relacionar palavras e imagens e para finalizar uma tarefa sobre fazer lista e ir ao supermercado comprar ingredientes para preparar o prato favorito do aluno. 
Vejamos na figura abaixo como a lição aqui proposta tem composição multimodal em seus textos:

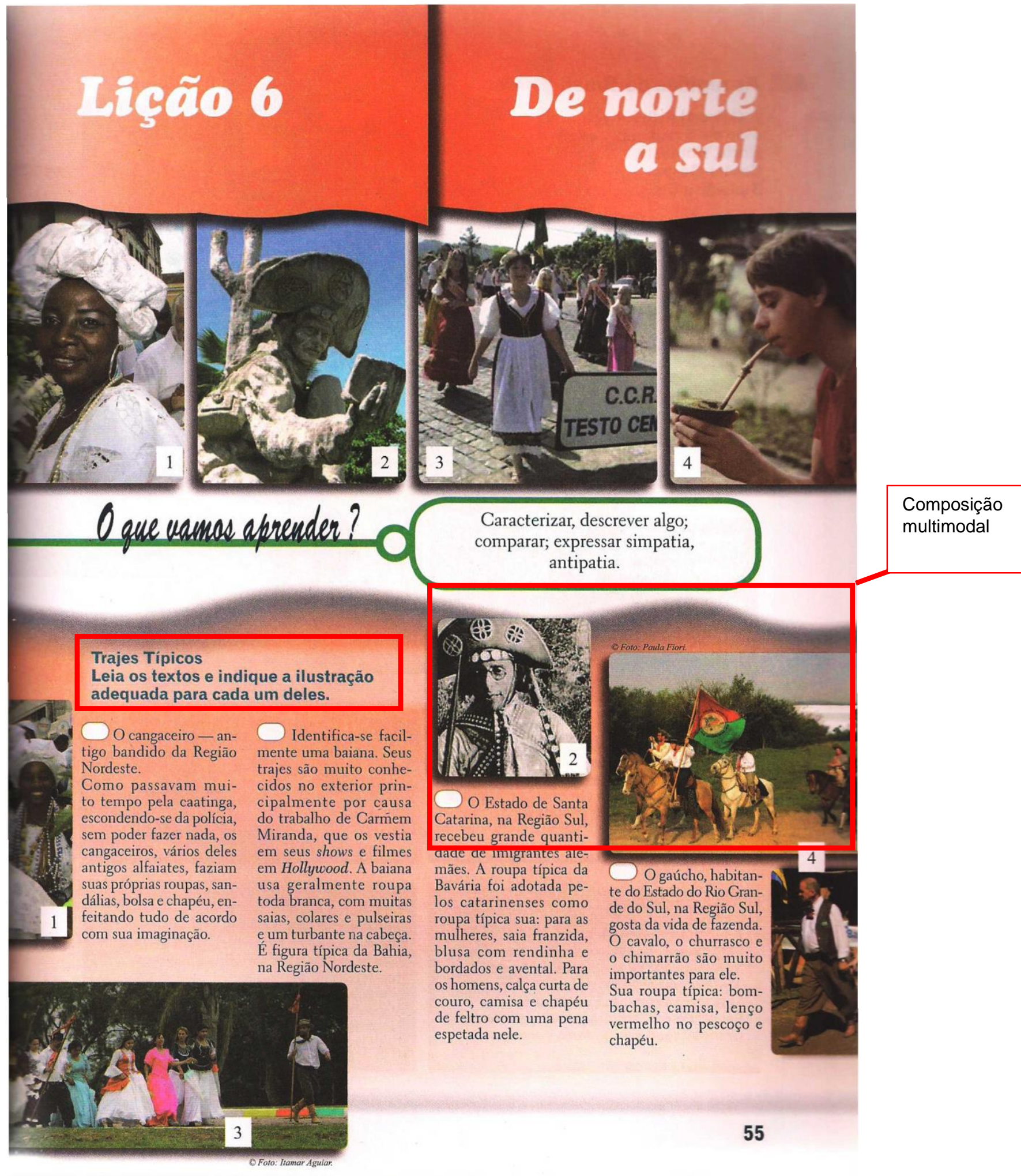

Figura 10: primeira página da lição 6 do livro Avenida Brasil 2 


\subsection{A ESCOLHA DOS TRÊS VÍDEOS DO YOUTUBE: OUTRAS CONSIDERAÇÕES}

Para Morán (1995, p. 29) "As linguagens da TV e do vídeo respondem à sensibilidade dos jovens e da grande maioria da população adulta. São dinâmicas, dirigem-se antes à afetividade do que à razão".

Nesta seção, discorreremos de forma mais completa sobre os três vídeos online selecionados no site YouTube para análise e inserção como pré-tarefa, tarefa em si e pós-tarefa nas unidades didáticas já apresentadas na seção anterior.

Sinalizamos desde o início deste trabalho que a escolha foi feita com base na acessibilidade, representatividade e no tempo de duração de cada vídeo. Esses três aspectos em conjunto nos levam a entender o vídeo online como mídia que conjuga em si as características da atualidade: informação em pouco tempo e espaço. Assim, consideramos que o vídeo online seria mídia de fácil acesso para um professor de PLE, uma vez que a própria proposta do YouTube é que os usuários da Internet tenham disponível ambiente democrático de troca de informações, além do fato de não haver necessidade de salvar o vídeo para uso posterior, já que qualquer computador com acesso à Internet possibilita esta ação, o que leva o YouTube para a sala de aula. Em seguida, consideramos algumas adequações dos vídeos para o trabalho em sala de aula de PLE, como ajustes no vocabulário, que deve ter linguagem clara e objetiva, além do tempo de duração, que deve figurar de curta a média (até 5 minutos), pois os vídeos online, no trabalho de suporte para as tarefas, não é o elemento central da atividade proposta, e sim parte dela, podendo ser utilizado antes do trabalho com o livro, como warm up para o assunto da unidade, para a própria tarefa, ou em momentos do pós-tarefa, em consonância com o que Morán (1995) critica como "só vídeo", ou seja, o vídeo apresentado de forma isolada, sem ligação com algum conteúdo, sem reflexão e ocupando todo o tempo de uma aula. Os vídeos também podem ser elementos motivadores para aumentar o desdobramento de uso da língua-alvo pelos alunos, pois trazem palavras-chave que possibilitam enriquecimento vocabular dos aprendentes. Outra possibilidade de uso dos vídeos são os momentos de reflexão sobre a atividade proposta, levando os 
aprendentes a exporem ideias entre si e com o professor, aplicando tais conteúdos (dos livros didáticos e dos vídeos) a suas situações da vida real.

Morán (1995, p. 29 - 30) diz que não há uma ordem rigorosa para trabalhar com o vídeo em sala de aula, pois pressupõe liberdade de adaptação à realidade de cada professor e dos seus alunos. Porém, este autor fala sobre usos inadequados dos vídeos em sala de aula, como:

\section{Usos inadequados dos vídeos em sala de aula:}

a) Vídeo tapa-buraco: colocar vídeo quando há um problema inesperado, como ausência do professor. Usar este expediente eventualmente pode ser útil mas, se for feito com frequência, desvaloriza o uso do vídeo e o associa - na cabeça do aluno a não ter aula.

b) Vídeo-enrolação: exibir um vídeo sem muita ligação com a matéria. O aluno percebe que o vídeo é usado como forma de camuflar a aula. Pode concordar na hora, mas discorda do seu mal uso.

c) Vídeo deslumbramento: o professor que acaba de descobrir o uso do vídeo costuma empolgar-se e passar vídeo em todas as aulas, esquecendo outras dinâmicas mais pertinentes. O uso exagerado do vídeo diminui a sua eficácia e empobrece as aulas.

d) Vídeo-perfeição: existem professores que questionam todos os vídeos possíveis, porque possuem defeitos de informação ou estéticos. Os vídeos que apresentam conceitos problemáticos podem ser usados para descobri-los junto com os alunos, e questioná-los.

e) Só vídeo: não é satisfatório didaticamente exibir o vídeo sem discuti-lo, sem integrá-lo com o assunto de aula, sem voltar e mostrar alguns momentos mais importantes

Quadro 4 - Sobre usos inadequados de vídeos em sala de aula (MORÁN, 1995, p. $19-30)$

Há algumas observações sobre como ver o vídeo, diante e juntamente com os alunos, em sala de aula. Morán (1995) alerta que, antes da exibição, devemos informar somente aspectos gerais do vídeo (autor, duração, prêmios etc.). Não interpretar antes da exibição, não prejulgar (para que cada um possa fazer a sua leitura). É necessário checar o vídeo antes. Conhecê-lo. Verificar se a qualidade do vídeo é adequada. Deixá-lo pronto antes da exibição. Durante a exibição do vídeo, frisar partes importantes. Se necessário, pausar o vídeo em 
certos momentos para comentários, do professor ou de alunos. Ficar atento e observar as reações do grupo. Depois da exibição, dar atenção às partes mais importantes ou difíceis. Se o vídeo for complexo, atentar sobre a necessidade de exibi-lo mais uma vez. Dar atenção à trilha musical, diálogos, situações. Observar o som, a música, os efeitos, as frases mais importantes.

Procederemos então às análises dos três vídeos online do YouTube já seguindo o expediente do Ensino Baseado em Tarefas, a Teoria da Multimodalidade e o Letramento Midiático. Os vídeos utilizados são:

1) "Preconceito e Estereótipo" (https://www.youtube.com/watch?v=7myuzFlipc) escolhido para trabalho com o livro "Novo Avenida Brasil (página 58, lição 6, seção A3 - Estereótipos)"

2) "Porto de Galinhas: CVC Viagens" (https://www.youtube.com/watch?v=01frfxRmfWk) escolhido para trabalho com o livro "Bem Vindo (unidade 18, página 176, exercício 7)

3) "Coisas que os brasileiros sabem que são verdadeiras" (https://www.youtube.com/watch?v=Kd-sOVHWgpA) escolhido para trabalho também com o livro "Novo Avenida Brasil" (página 58, lição 6, exercício 3, onde os alunos falarão sobre como veem a gente de seu país)"

\subsubsection{O vídeo online do YouTube "Preconceito e Estereótipo"}

O vídeo intitulado "Preconceito e Estereótipo" será utilizado em momento pré-tarefa na unidade 18 do livro "Bem-Vindo!", na página 176, exercício 7, em que os alunos deverão criar um folheto informativo para uma agência de viagens a fim de fazer propaganda de seu país. Este vídeo tem duração de 4.14 minutos. O vídeo foi postado pelo perfil "Minutos Psíquicos", em 10 de julho de 2014, e tem a seguinte descrição: "Você sabe qual é a diferença entre preconceito, estereótipo e discriminação? E você sabia que é possível possuir preconceito contra um grupo sem ter consciência desse preconceito? Essas são algumas das questões que exploraremos no vídeo hoje".

Este vídeo, quando acessado no dia 09/02/2015, tinha 26.543 acessos, com 2.899 avaliações positivas e 7 negativas. 
Segundo Willis (1996) a etapa do pré-tarefa é geralmente a etapa mais curta, e tem como principais objetivos:

- Apresentar o tópico da tarefa, despertando o interesse dos alunos em participar

- Promover a exposição da língua alvo, de modo a ajudar os alunos a lembrar e ativar ou apresentar vocabulário útil à realização da tarefa

- Garantir que todos os alunos tenham compreendido o que a tarefa envolve, quais os seus objetivos e quais resultados serão produzidos ou esperados

Dessa feita, por se tratar de vídeo de curta duração, cujo tema sinaliza o que será tratado na unidade didática selecionada, este vídeo promove a reflexão inicial sobre estereótipos. Vale ressaltar que a semiose imagética apresentada, por ser de simples grafismo (desenhos com poucos detalhes e de reconhecimento fácil), promove o visionamento dos conceitos apresentados no áudio, assim, os alunos podem ser encorajados ao debate, de forma diferente de uma leitura uníssona, sem muito aproveitamento, expediente comumente empregado em momentos de warm up. 
A seguir, na figura abaixo, temos os componentes do esquema empregado no Ensino Baseado em Tarefas, de Willis (1996, p. 38):

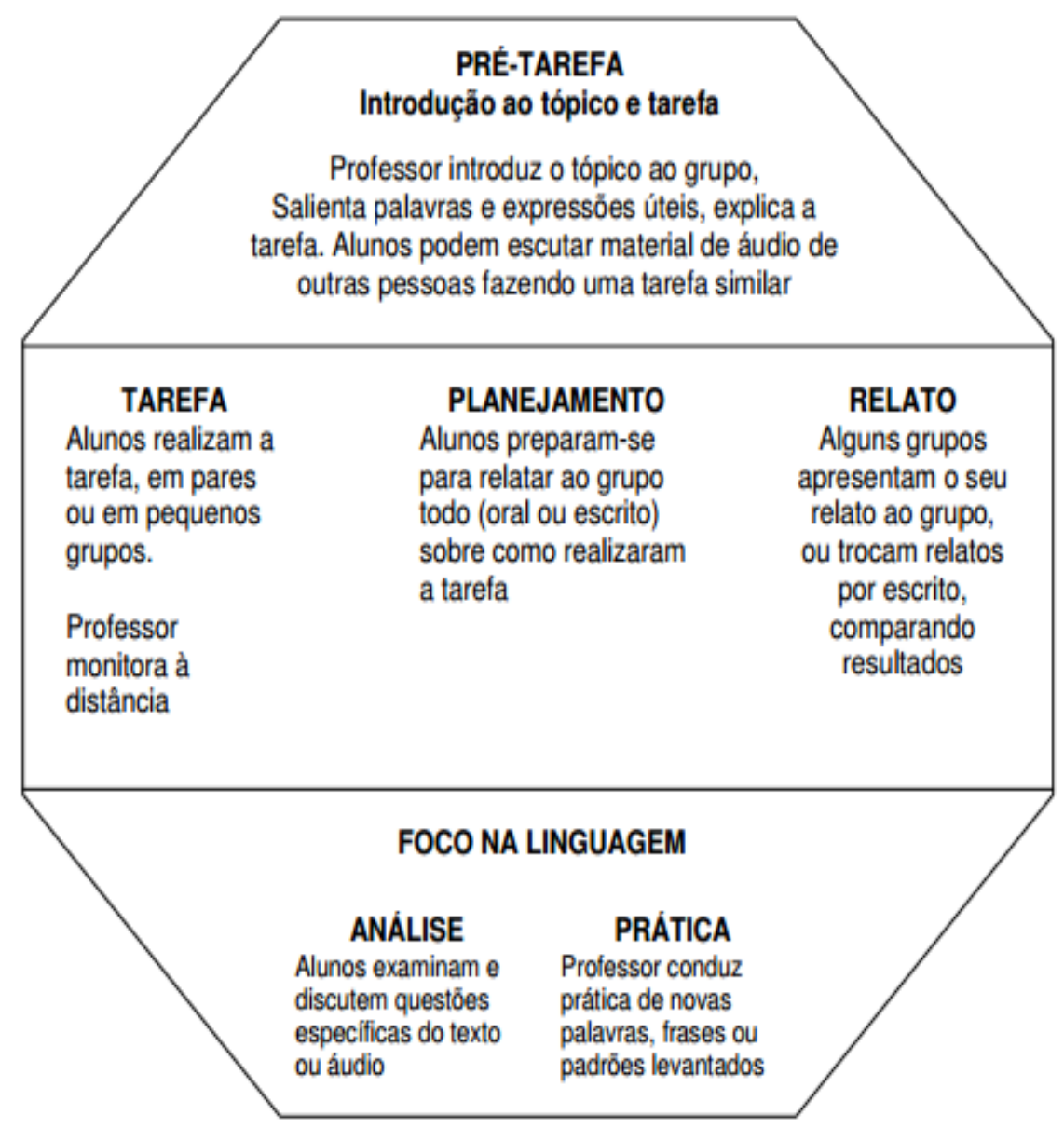

Figura 11: sobre os componentes do esquema de trabalho do Ensino Baseado em Tarefas (WILLIS, 1996, p. 38)

Antes de descrevermos a inserção do vídeo como pré-tarefa, falaremos um pouco sobre qual exercício da unidade didática receberá o vídeo online. 0 exercício A3 da página 58 do livro Avenida Brasil 2 apresenta algumas generalizações sobre o que seriam estereótipos no Brasil. Como exemplo disso, cita quem é o carioca, o paulista, o mineiro e o gaúcho. Isso é feito por meio de texto verbal e imagens, no caso, essas são desenhos que remetem às características consideradas típicas de cada tipo regional. Por se tratar de tema controverso, é que a inserção do vídeo anteriormente a este exercício pode ser benéfica para o debate. 
Segue o exercício que irá receber o vídeo sobre estereótipos no momento pré-tarefa.

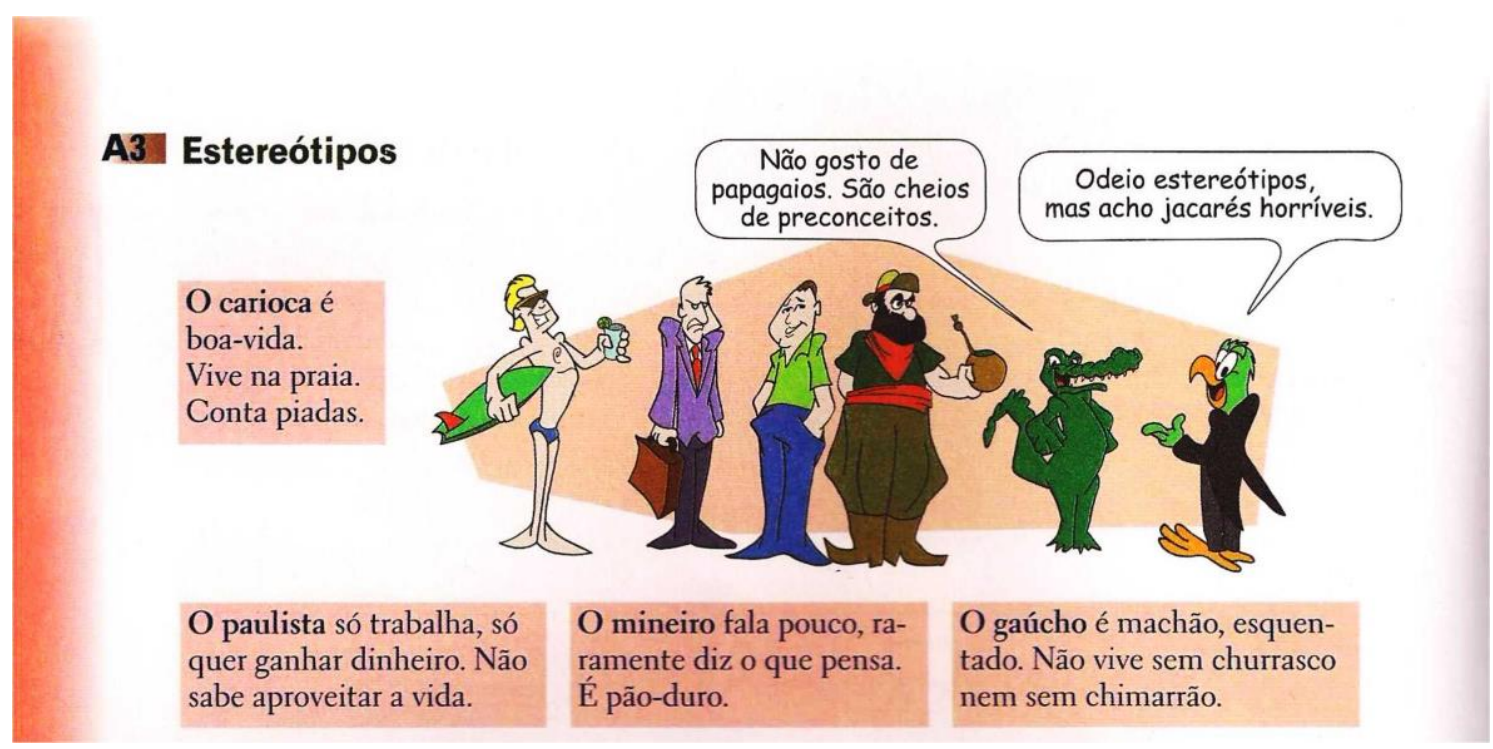

Figura 12: exercício do livro Avenida Brasil 2 sobre estereótipos

A proposta multimodal pode auxiliar o docente no planejamento do prétarefa, considerando a potencialidade de significação dos recursos semióticos imagético e sonoro em um vídeo que, vinculado ao que é tratado na unidade didática, promove o letramento midiático do aprendente no que tange ao uso social da língua alvo.

A sequência do vídeo apresentada a seguir será detalhadamente analisada.

Como podemos verificar, o pré-tarefa é o momento de introdução do tópico ao grupo de aprendentes. Por se tratar de vídeo que promove reflexão crítica acerca do que sejam estereótipos, cabe aqui ressaltar o que Kress e van Leeuwen (1996) chamam de categoria dos participantes representados.

Como dito anteriormente, essa categoria diz respeito aos participantes sobre os quais se está falando, escrevendo ou produzindo imagens. A introdução ao tema estereótipos se dá pelo tratamento da diferença entre preconceito, estereótipo e discriminação. $O$ autor do vídeo promove reflexão sobre como é possível possuir preconceito contra um grupo sem ter consciência disso. Podemos ver que as representações imagéticas da sequência elegem 
elementos que ligam ações a pessoas brancas ou a pessoas negras, conforme estereótipos convencionados socialmente. Todo esse exercício pode ser feito em warm up como preparação para os aprendentes entenderem melhor o significado de estereótipos. Ao destacar como participantes representados, uma pessoa branca, uma pessoa negra e o jogo de indução entre arma e furadeira (objetos próximos), o produtor do vídeo elege as formas que considera mais plausíveis de representação daquilo que deseja significar, isso é o que se chama na Teoria da Multimodalidade de potencialidade de significação.

Em um trabalho sistematizado de Ensino Baseado em Tarefas, aliado ao que preconiza a Teoria da Multimodalidade, temos um caminho viável para essa etapa do pré-tarefa como forma de Letramento Midiático no Ensino de LE. Isso porque o aprendente estará lidando com um exercício de reflexão crítica sobre estereótipos da língua alvo por meio do emprego de diferentes recursos semióticos: imagem, texto e som. Tudo parte de sua prática discursiva cotidiana.

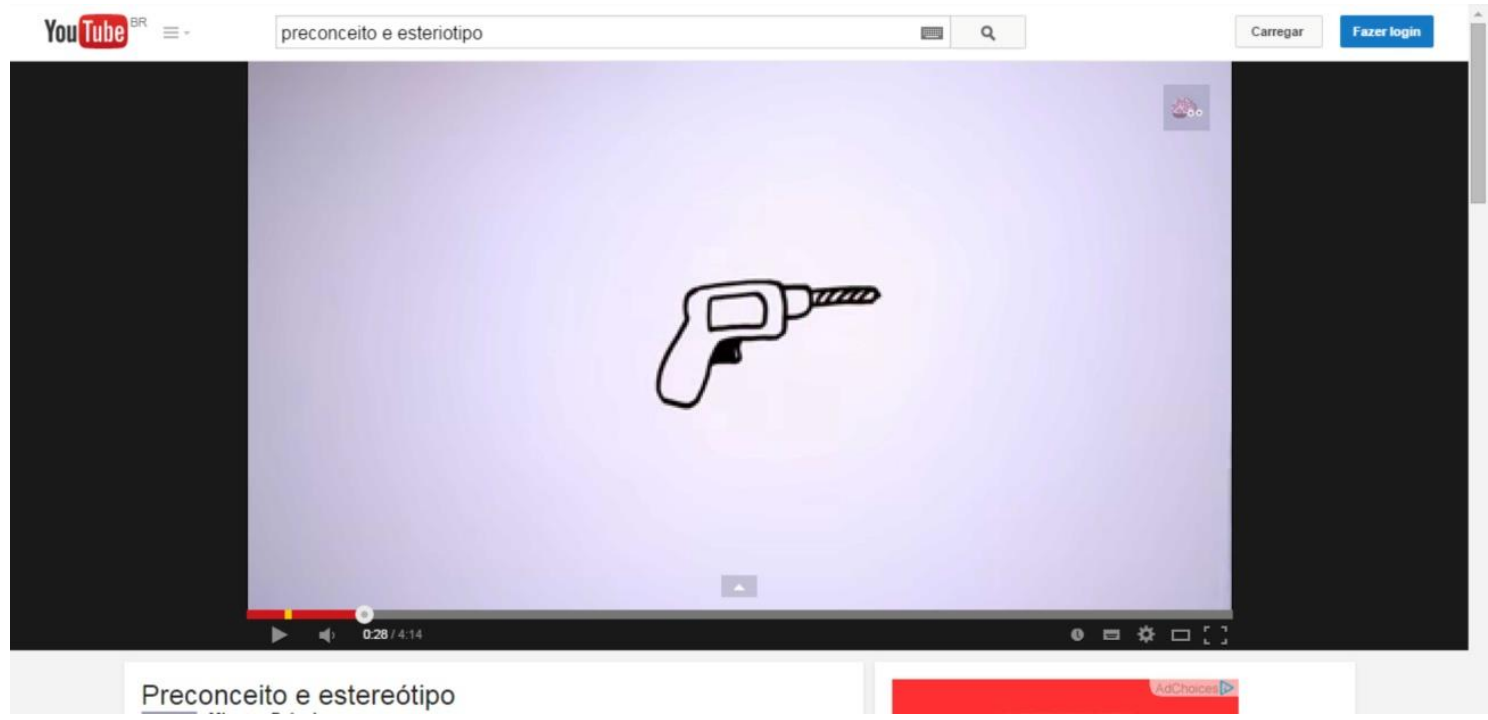

Figura 13: imagem de uma furadeira 


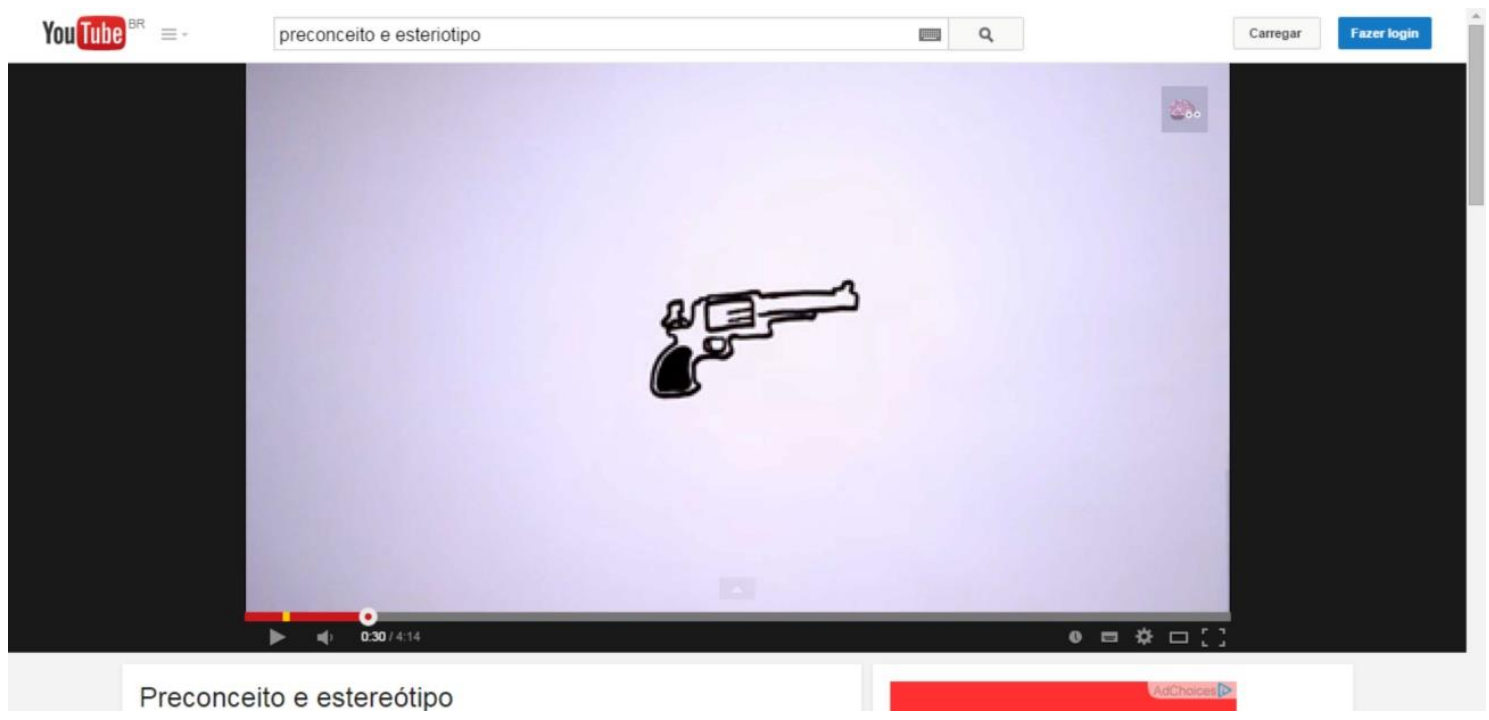

Figura 14: imagem de um revólver

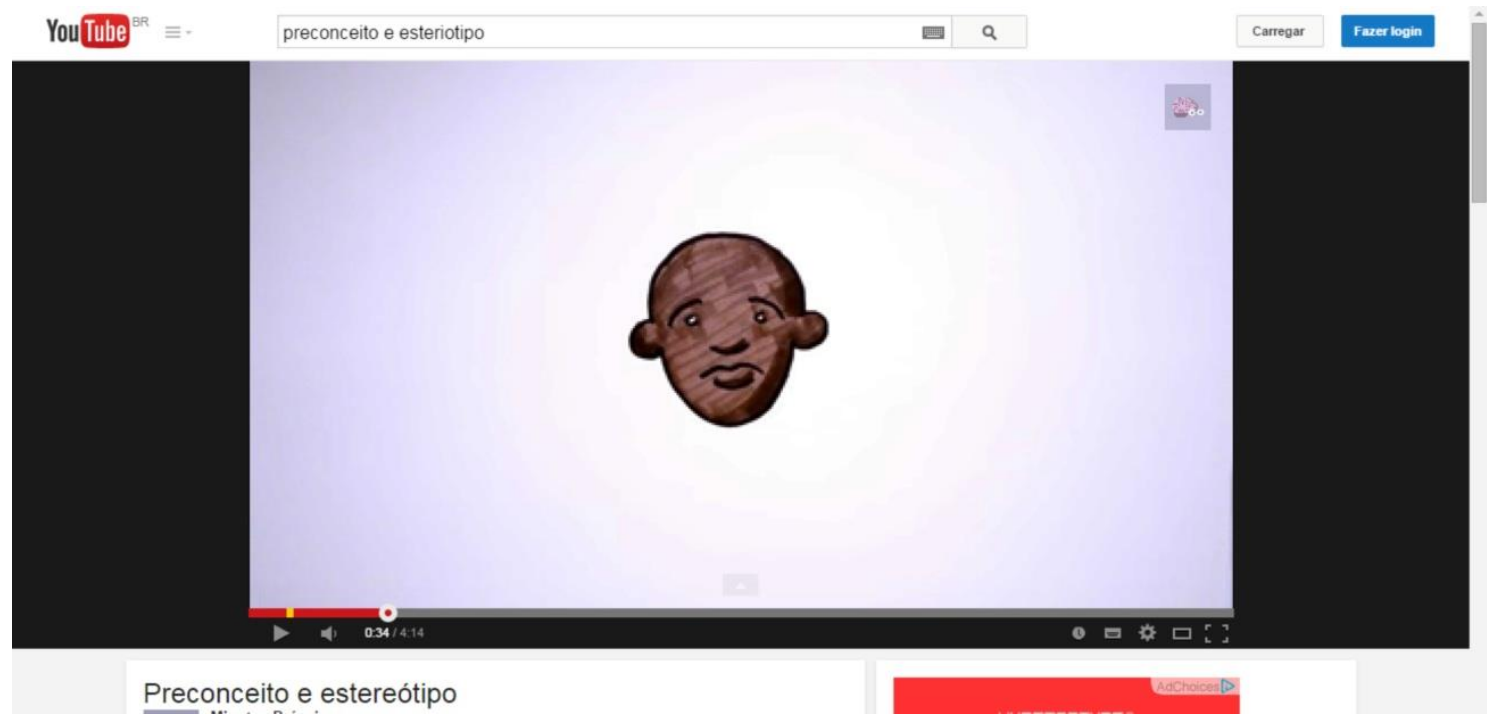

Figura 15: imagem de uma pessoa de cor negra 


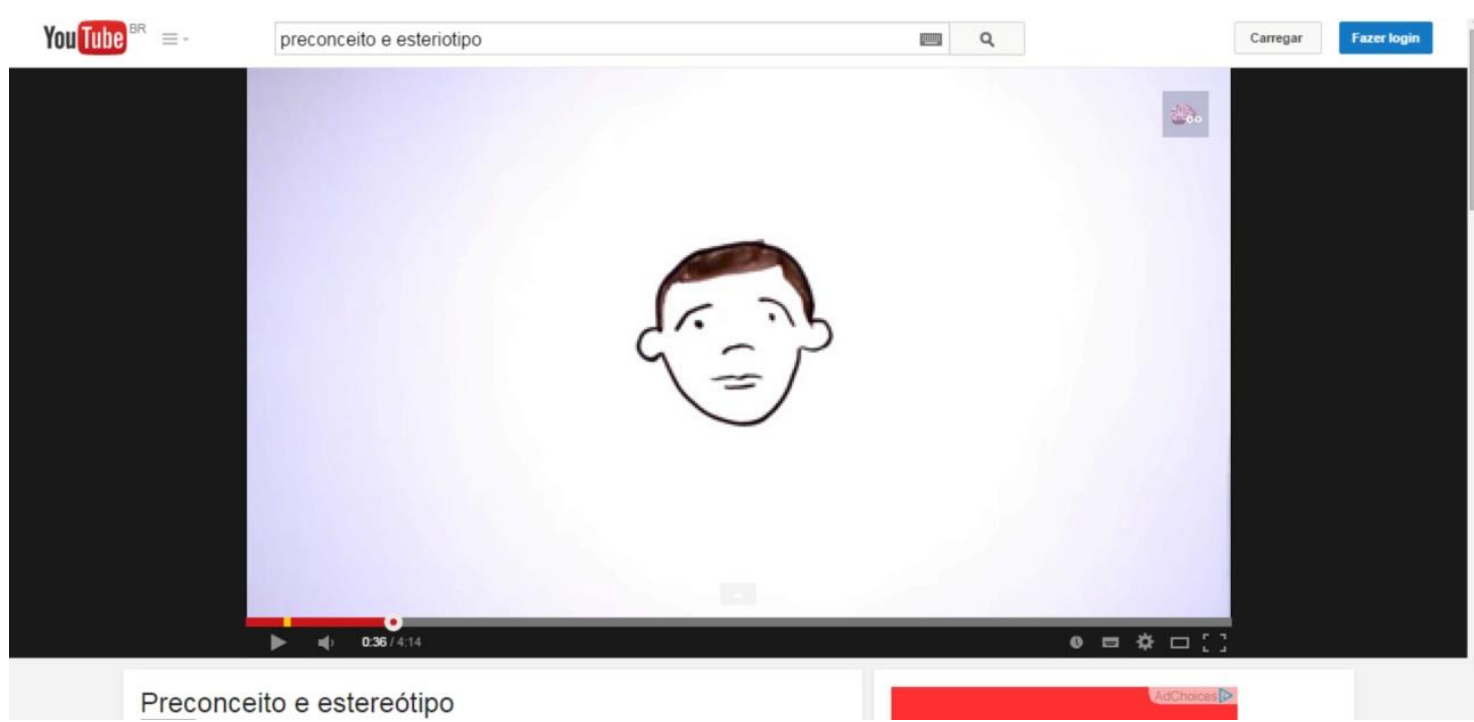

Figura 16: imagem de uma pessoa de cor branca

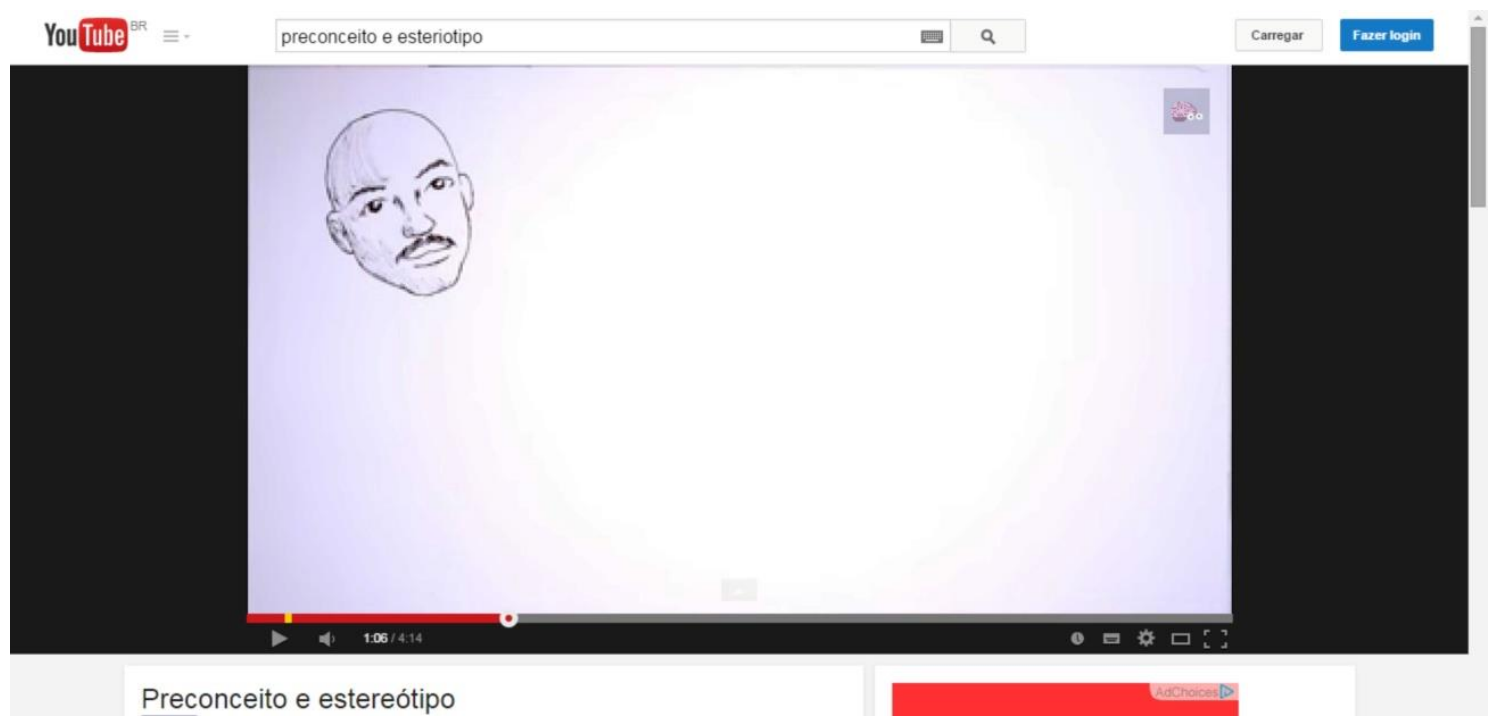

Figura 17: imagem de um jovem imigrante nos Estados Unidos 


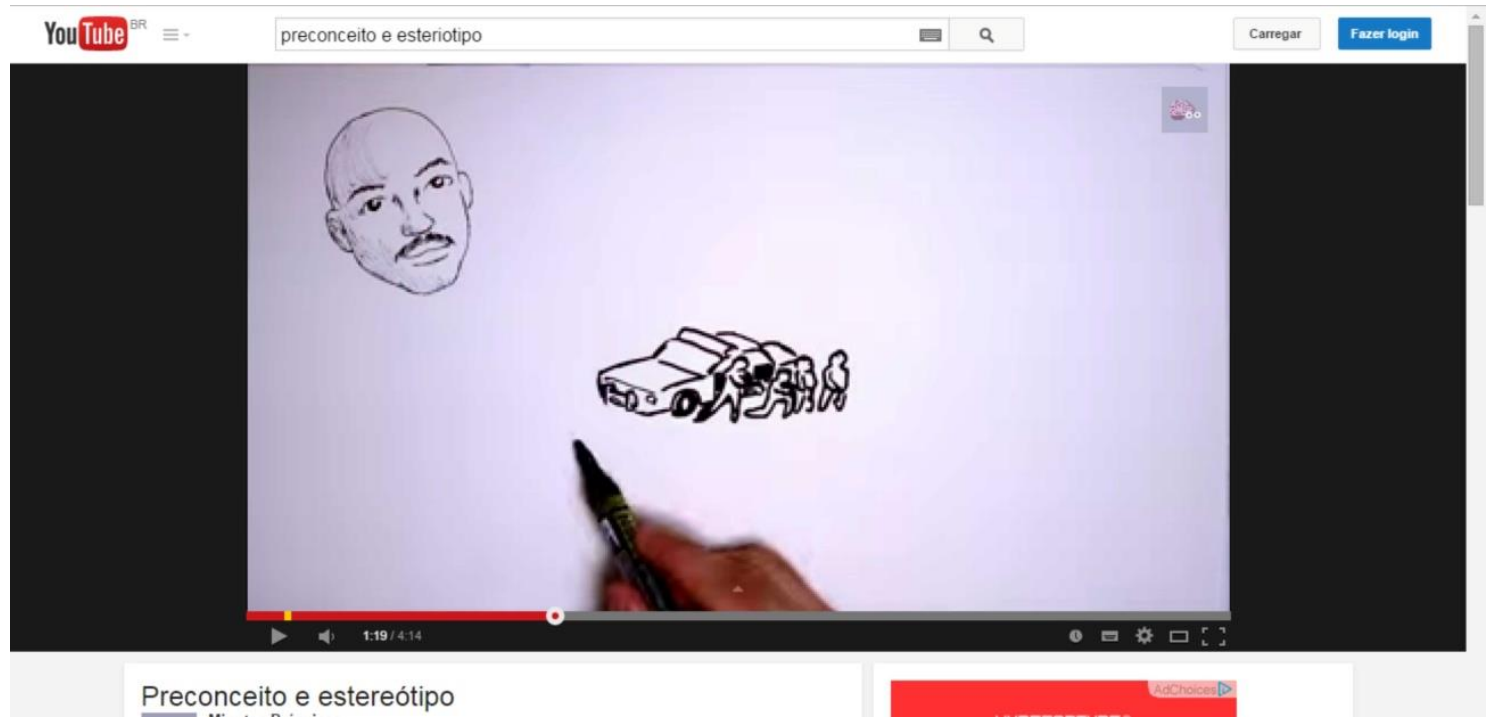

Figura 18: imagem de um jovem imigrante nos Estados Unidos e policiais

\subsubsection{O vídeo online do YouTube "Porto de Galinhas - CVC Viagens"}

O vídeo intitulado "Porto de Galinhas - CVC Viagens" será utilizado no momento da tarefa do livro "Novo Avenida Brasil 2", na página 58, lição 6, seção A3 sobre estereótipos. Este vídeo, quando acessado no dia 09/02/2015, tinha 87.622 acessos, com 43 qualificações positivas e 2 negativas. Trata-se de um vídeo institucional da empresa de viagens CVC, em que se apresentam várias opções de lazer que justificariam uma viagem para Porto de Galinhas, Pernambuco. O vídeo pauta-se nas belezas naturais do local, como praias de areia branca, coqueirais, eventos culturais, além da culinária que os turistas podem aproveitar.

O momento da aplicação da tarefa em si, que Willis (1996) chama de ciclo da tarefa, é dividido em três etapas segundo este autor: tarefa, planejamento e relato. Para Willis, durante a etapa da tarefa o professor deve "parar de ensinar" e apenas monitorar os aprendentes, não sendo recomendável ficar muito próximo aos grupos, a fim de evitar que recorram ao professor sempre que encontrarem alguma dificuldade.

No caso deste vídeo da empresa CVC sobre Porto de Galinhas, os alunos teriam a oportunidade de elencar motivos pelos quais é viável visitar determinado ponto turístico, pois a narrativa nele ressalta as características do local. $\mathrm{Na}$ unidade didática, esse vídeo será apresentado aos aprendentes depois da leitura 
de folhetos turísticos anteriormente propostos. Como foi feita leitura de material impresso, isso significa que os aprendentes já estão familiarizados com o tema em estudo. Vejamos, mais uma vez, o exercício 7 da unidade 18 do livro BemVindo!:
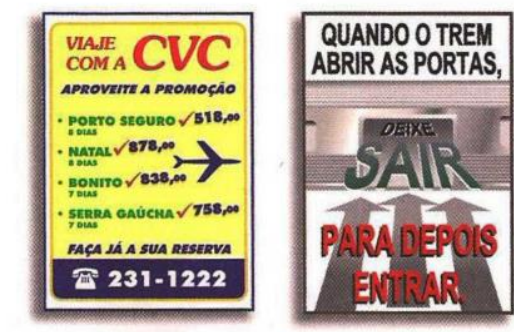

Observe os seguintes folhetos informativos e publicitários. 0 que eles têm em comum é o tempo verbal: o IMPERATIVO. Por que será que os especialistas em publicidade usam tanto o Imperativo? Pesquise e discuta com seu colega/professor.

Agora vamos criar um folheto informativo para uma agência de viagens a fim de fazer propaganda do seu país, da sua beleza, da sua cultura. Deve ser o mais atraente, convidativo e convincente possível. Use e abuse do IMPERATIVOI Coloque também um título sugestivo para o folheto.
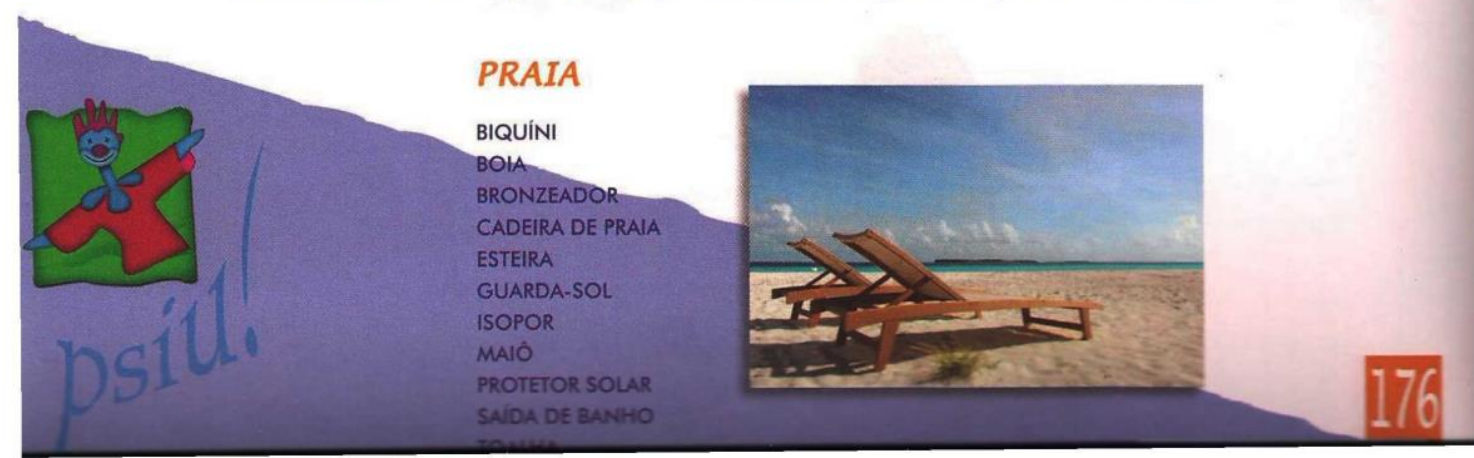

Figura 19: Exercício 7 da unidade 18 do livro Bem-Vindo!

Agora, o vídeo amplia as impressões sobre um local específico para turismo, na costa litorânea brasileira. Ainda se trata de um vídeo de curta duração, o que favorece o debate e facilita as possibilidades de intervenção do docente. O vocabulário pode ser trabalhado quadro a quadro. Segundo Kress e van Leeuwen (1996), os viewers, leitores de textos imagéticos, são o públicoalvo desses textos. Esse papel aqui é desempenhado pelos aprendentes, uma vez que são eles os viewers do vídeo em questão. Vale ressaltar que estamos, ainda, tratando da categoria dos participantes da Teoria da Multimodalidade.

Outra categoria da Multimodalidade de grande relevância para a análise diz respeito à composição espacial do significado, que se refere a significados representacionais e interativos. Destacamos, aqui, o valor da informação, a saliência e o framing (enquadramento), que se referem ao lugar, aos diferentes 
graus dos planos e à presença ou ausência de divisão de molduras entre os elementos, no caso, participantes e sintagmas que se relacionam entre si e o leitor (viewer).

Na sequência de quadros apresentada abaixo, temos três situações em que os participantes representados são turistas em visita a Porto de Galinhas. Todas as atividades desses participantes demonstram ao viewer como esse local turístico oferece diferentes oportunidades de lazer.

O primeiro quadro é de turistas em um passeio de bugre, atividade comum no nordeste brasileiro, e que atrai os visitantes. O valor da informação aqui está no destaque dado aos próprios turistas, outros sintagmas da imagem, como o bugre, servem de moldura ou enquadramento para o reforço da identidade de turista na cidade de Porto de Galinhas.

O segundo quadro mostra turistas em um banho de piscina natural. A saliência, que se refere ao efeito produzido para atrair a atenção do viewer aqui está na beleza natural do local. Esse efeito coloca em destaque a cor azul da água da piscina, o que direciona o olhar para esse sintagma da imagem.

O terceiro quadro é marcado pelo framing, que conecta os elementos da imagem de forma a representar e destacar a ação do turista em visita a um restaurante típico praiano.

O que podemos inferir é que a composição desses vídeos como textos multimodais nasce como produto de vários códigos, que analisados separadamente, ou de maneira integrada, demonstram que as imagens não são aleatoriamente produzidas. Todas elas dão destaque a elementos que pertencem a uma mesma temática, no caso, um ponto turístico brasileiro, e todas as possibilidades que este oferece. Quando inserido em tarefa em si, esse vídeo potencializa o significado trabalhado durante a unidade didática do livro de PLE, o que favorece, mais uma vez, o letramento midiático durante o processo de ensino-aprendizagem da língua alvo, uma vez que o aprendente por meio do suporte de diferentes recursos semióticos pode ter sua argumentação enriquecida na língua-alvo. 


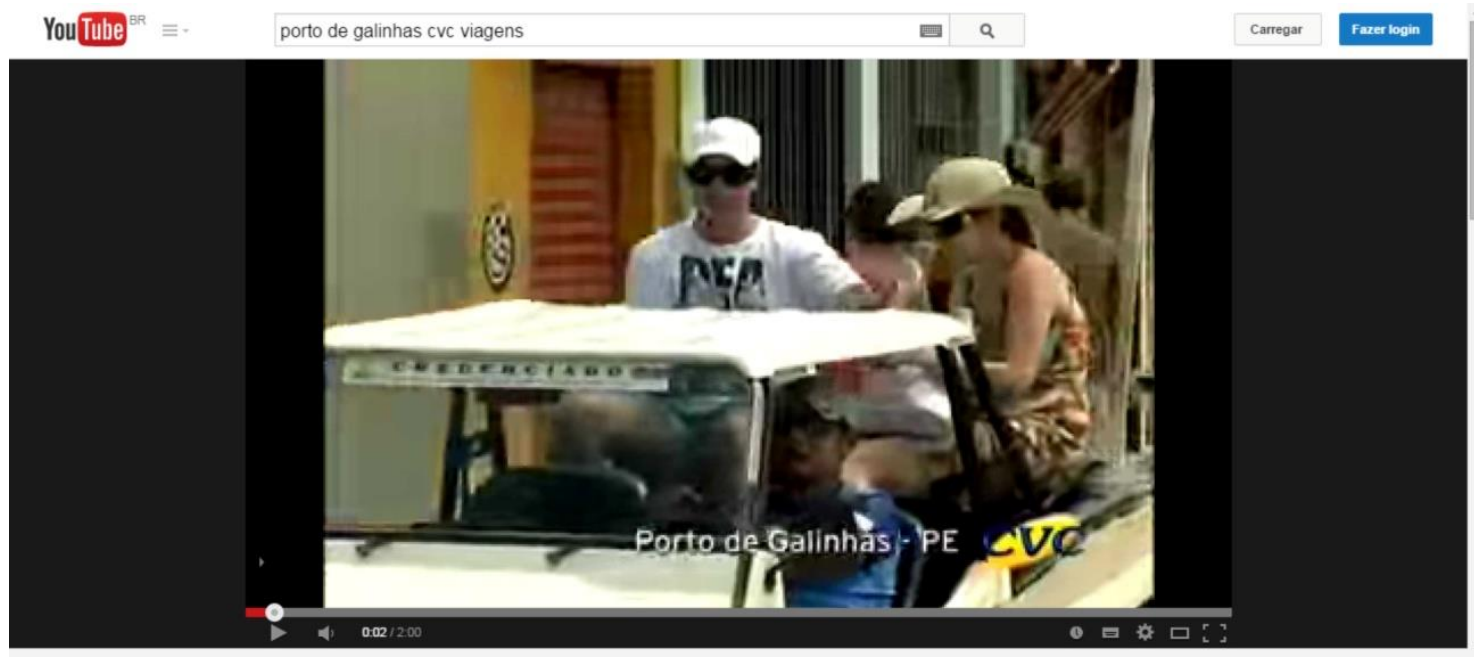

Porto de Galinhas | CVC Viagens

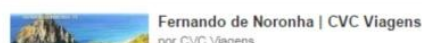

Figura 20: turistas em passeio de bugre e Porto de Galinhas

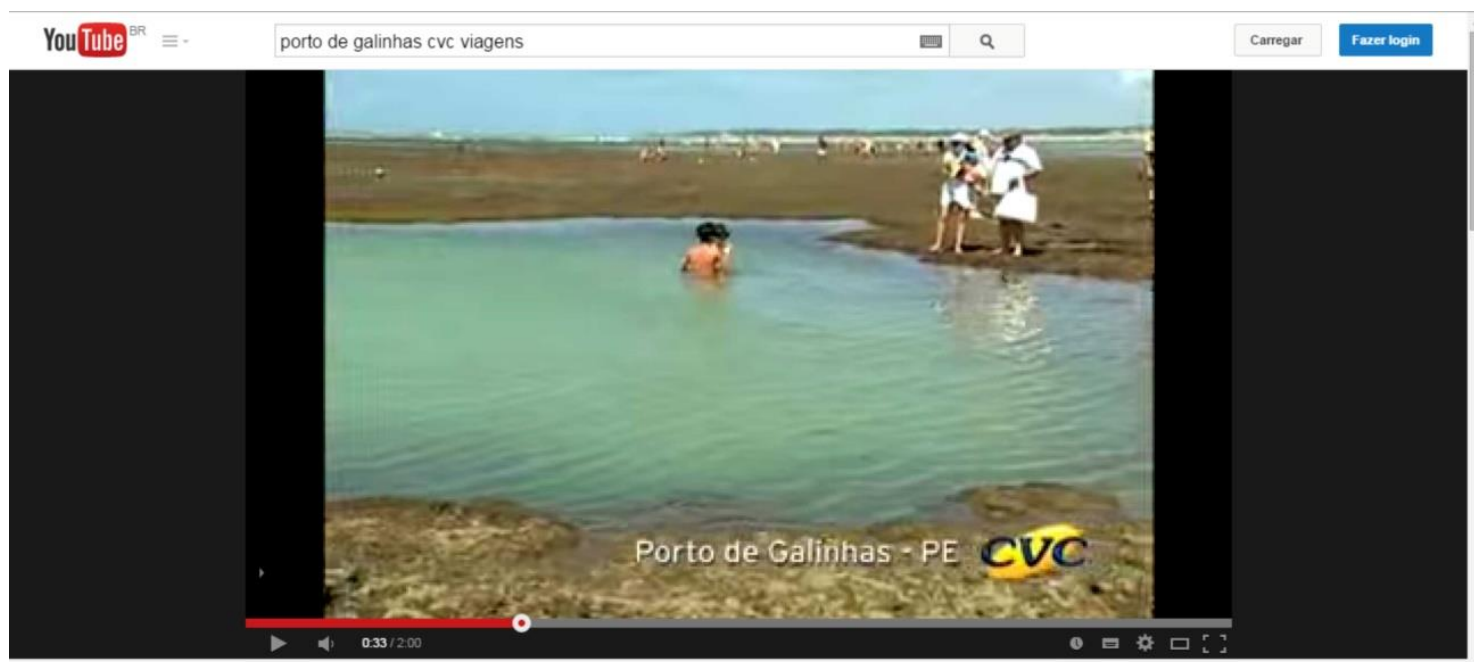

Porto de Galinhas | CVC Viagens

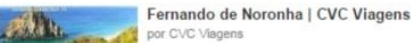

Figura 21: turistas em piscina natural de praia de Porto de Galinhas 


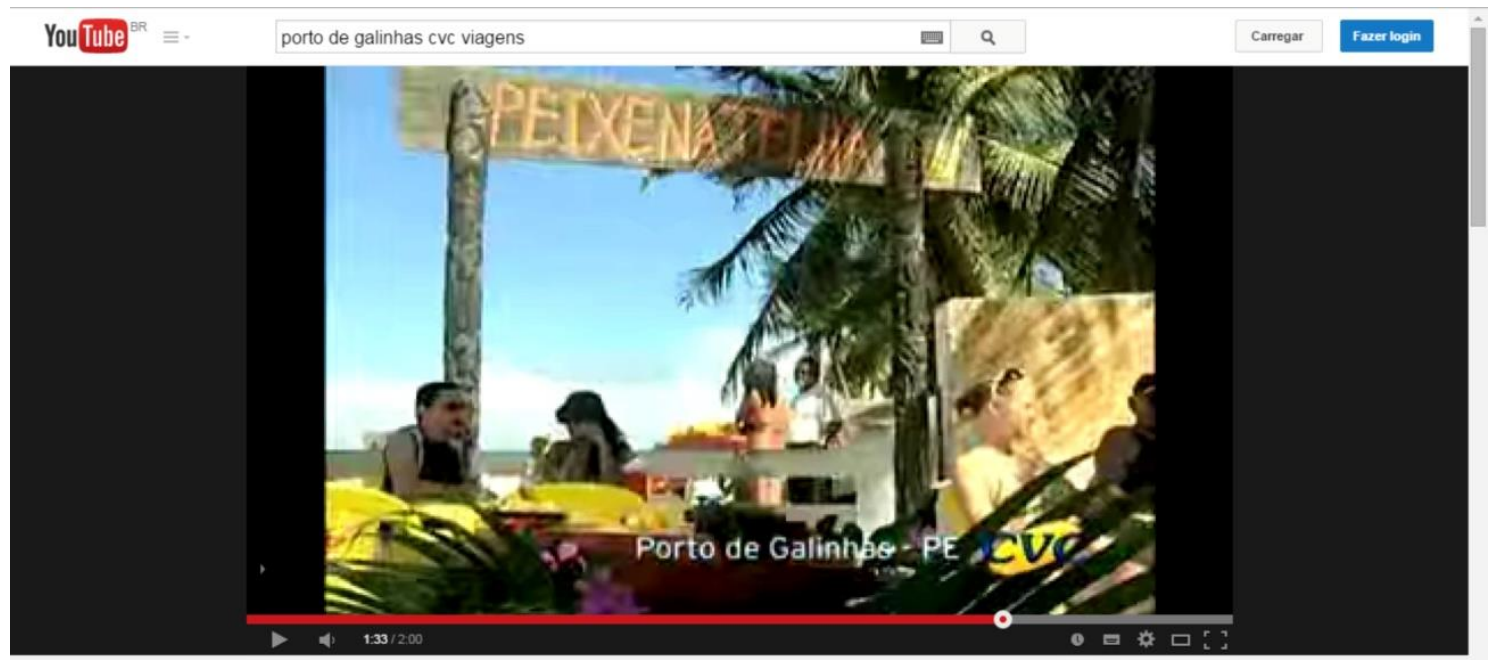

Porto de Galinhas | CVC Viagens

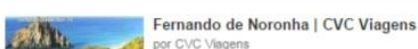

Figura 22: turista em restaurante típico de praia no Brasil

\subsubsection{O vídeo online do YouTube "Coisas que os brasileiros sabem que são verdadeiras"}

O vídeo intitulado "Coisas que os brasileiros sabem que são verdadeiras" pode ser utilizado no momento pós-tarefa do livro "Novo Avenida Brasil 2", página 58, lição 6 , exercício 3, em que os aprendentes falarão sobre como veem o povo do país de sua língua alvo. Este vídeo mostra algumas generalizações sobre o Brasil e seu povo, em relação aos costumes e cultura do país.

Este vídeo, quando acessado no dia 09/02/2015, tinha 126.162 acessos, com 2.668 qualificações positivas e 1.482 negativas. Diferentemente dos outros dois vídeos, o número de negativas deste é maior. Esse dado, na verdade, não nos desencorajou a escolha, e sim a reforçou, justamente por se mostrar um contraponto a ser trabalhado. Como se trata de vídeo que apresenta várias generalizações sobre o que o brasileiro sabe sobre si, cabe como forma de desvelar diversos mitos do senso comum. Se não contar com planejamento do docente, ou mesmo com o conhecimento da potencialidade de significação dos recursos semióticos nele presentes, poderia ter efeito reverso ao pretendido.

Vamos em seguida à explanação da proposta com base na análise realizada.

Como este vídeo será aplicado no momento pós-tarefa, faremos algumas considerações sobre esta fase do processo de ensino-aprendizagem. No ensino de LE é importante que se promova a interação na língua alvo, para tanto, o pós- 
tarefa representa o momento em que há a possibilidade de que alguma atividade seja voltada para aspectos linguísticos trabalhados ao longo da tarefa, sem que o objetivo comunicativo seja colocado em risco.

No livro Avenida Brasil 2, o exercício 3 da página 58 pede que os aprendentes façam o emprego de algumas expressões da língua portuguesa já introduzidas ao longo da unidade. Para que esse emprego não seja feito de forma mecânica, a inserção do vídeo online "Coisas que os brasileiros sabem que são verdadeiras" pode promover exercício reflexivo crítico sobre o tema estereótipos, já tratado em outros momentos por meio da apresentação de diferentes recursos semióticos, que exploram ricamente o tema proposto. Vejamos então a figura com o exercício original:

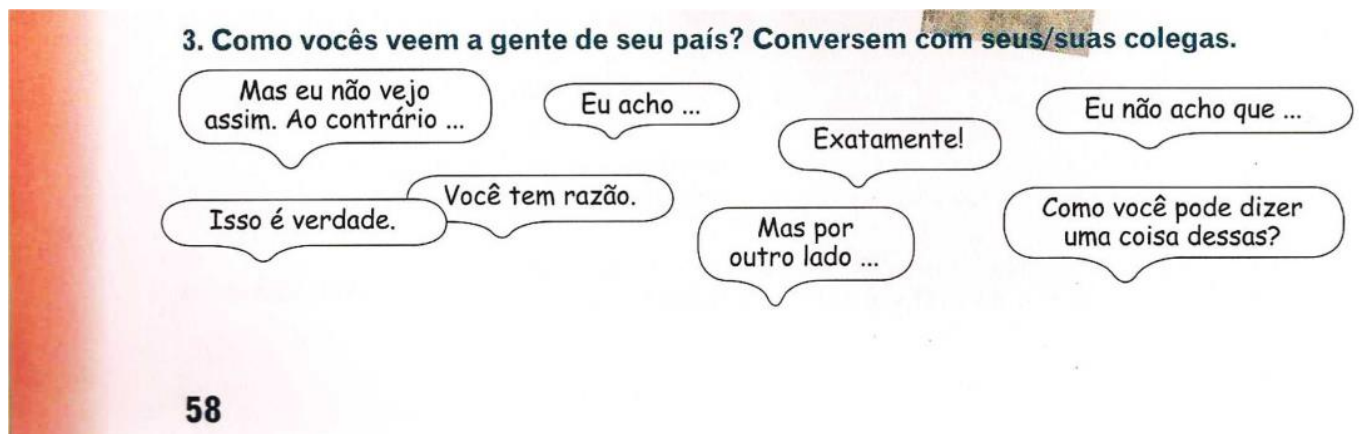

Figura 23: exercício 3 da lição 6 do livro Avenida Brasil 2

A inserção do vídeo neste exercício fomentaria o debate em torno de estereótipos, ao mesmo tempo em que colocaria em prática as expressões linguísticas em estudo. Passemos à análise multimodal do vídeo.

Kress e van Leeuwen (1996) apontam, dentro dos processos narrativos, o processo de ação, em que o ator é o participante do qual o vetor de ação se origina, no caso, o primeiro quadro da sequência a seguir mostra o que seria uma brasileira que representa a mensagem do texto verbal que diz que "primeiro, o Brasil é mais do que as suas [praias]". Pelo contraste com o segundo plano, vemos que este participante representado está em destaque. O vetor do seu olhar não se dirige a um objeto, o que significa um processo não-transitivo. Isso significa que 0 ator tem uma ação similar à estrutura intransitiva verbal, na qual não há necessidade de complemento. Assim, o que não está escrito está no 
imagético, em que a mensagem está completa, de forma intransitiva, a mulher representa esse Brasil que é mais que somente praias. A narrativa sempre se pauta nas três modalidades: imagem, texto e som.

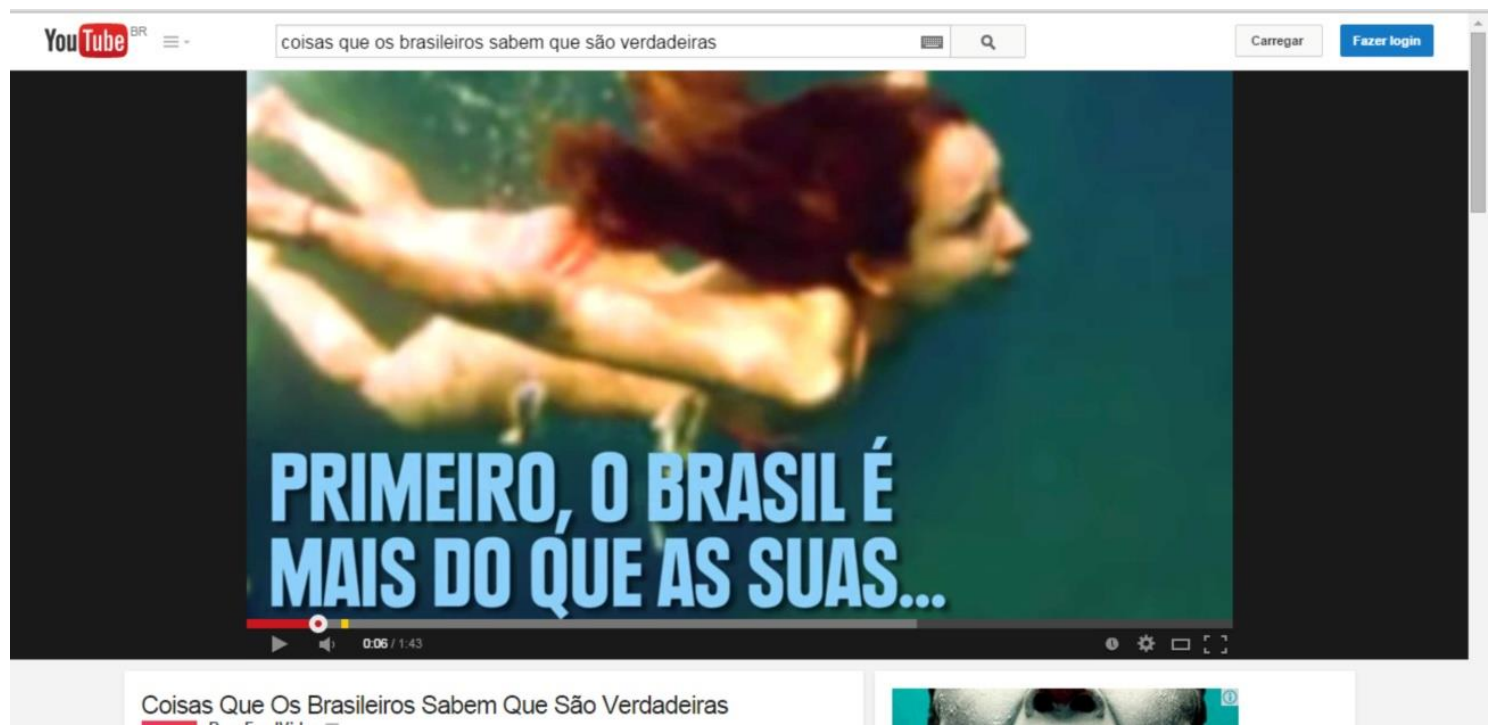

Figura 24: turista mergulhando no mar da costa litorânea brasileira

No segundo quadro, temos a representação da caipirinha, bebida típica brasileira, que se transformou em um dos ícones do país. A narração do vídeo fala que o Brasil é muito mais que suas caipirinhas. Aqui o objeto "caipirinhas" ganha destaque pela saturação de proeminência da cor e perspicácia do foco, através da saliência. Para os viewers, esse processo é simbólico, porque ressalta o que o participante significa ou é nas fotos, no caso, a caipirinha é um símbolo do Brasil. 


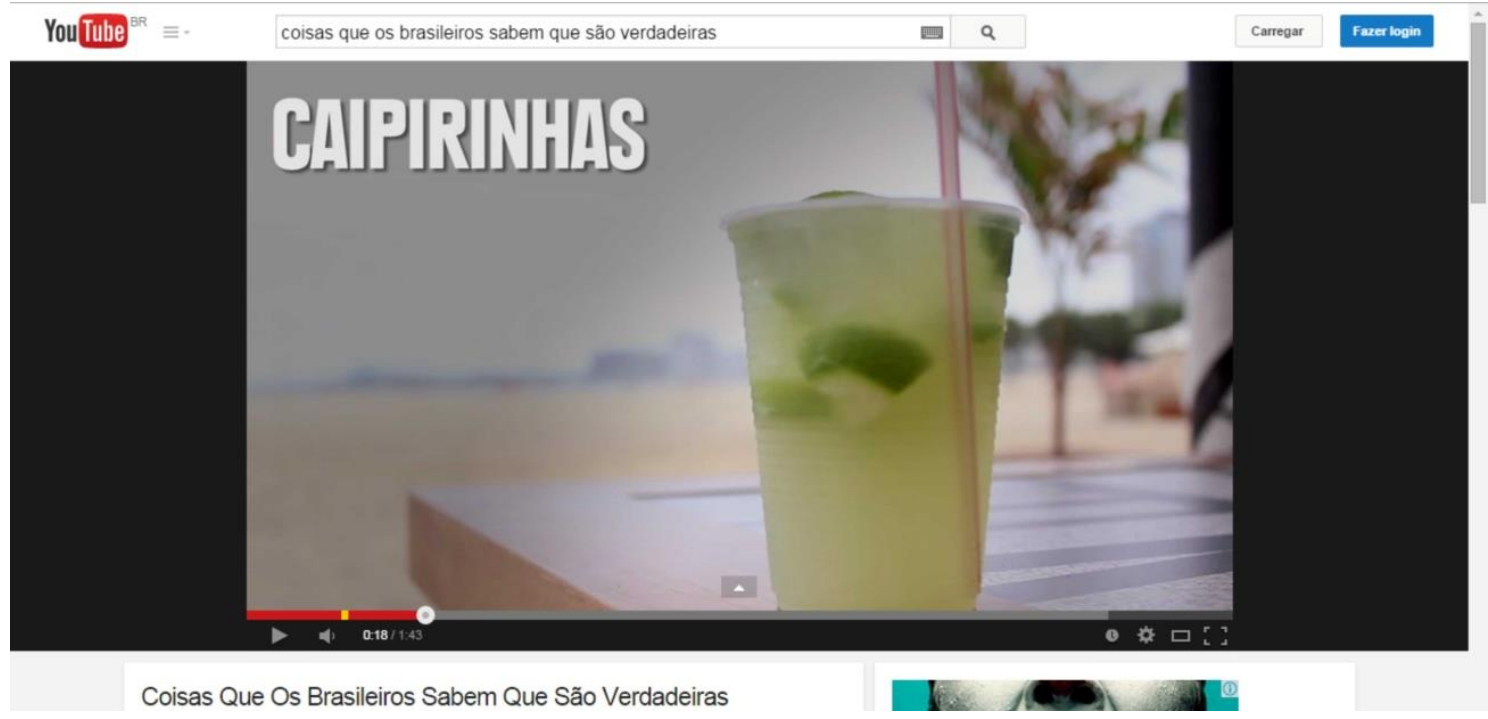

Figura 25: representação da caipirinha

Os dois quadros a seguir relatam os participantes por meio de explanações verbais acerca de música e dança. No caso, o saber dançar como característica típica do brasileiro e o sentimento de orgulho pelo carnaval de cada cidade. Esse processo ainda se enquadra no processo classificatório, dentro do processo narrativo.

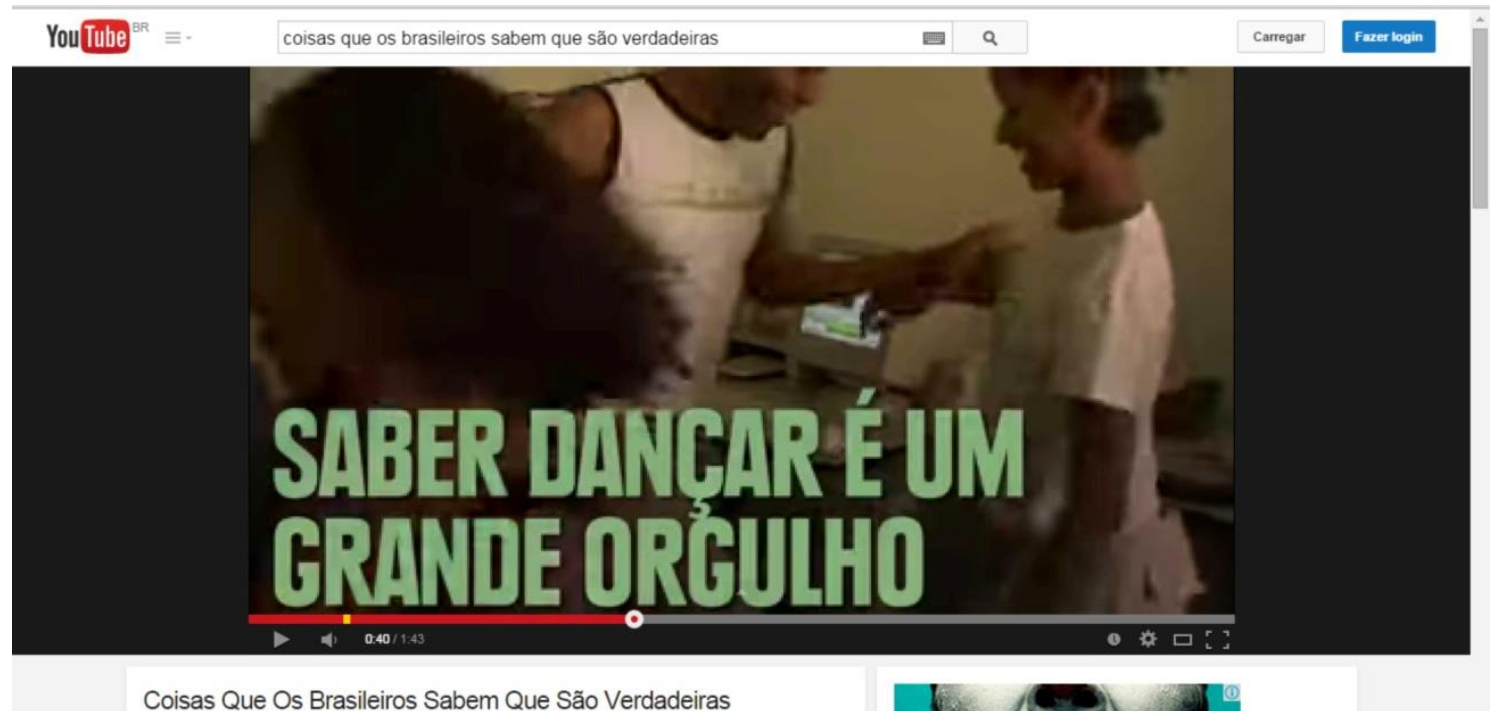

Figura 26: brasileiros dançando 


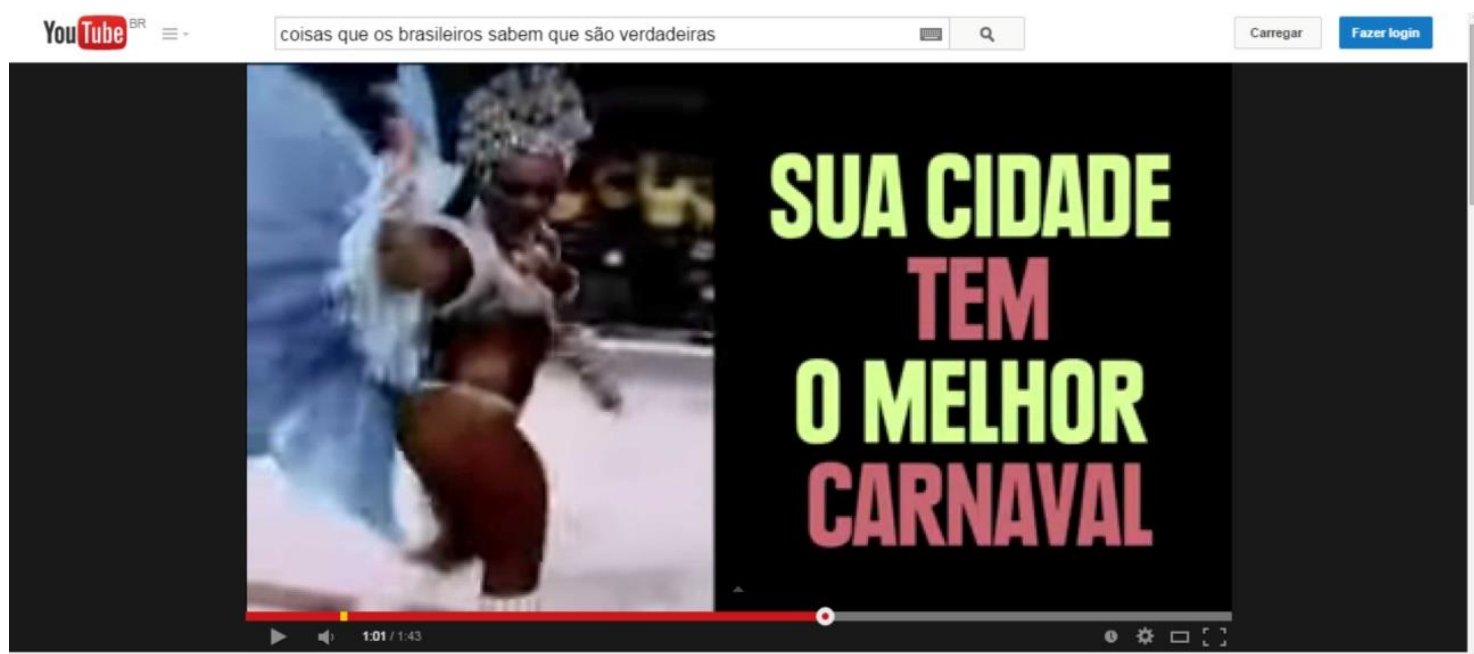

Coisas Que Os Brasileiros Sabem Que São Verdadeiras

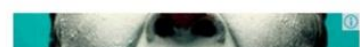

Figura 27: desfile de carnaval brasileiro

Neste quadro, há uma frase recorrente no Brasil que se refere à crença de que Deus é brasileiro. Ao lado dessa frase, como participante representado eleito, está outro ícone bastante conhecido do Brasil, o Cristo Redentor. Esta composição multimodal demonstra um processo dentro do narrativo: o simbólico, em que um participante significa algo como é o Cristo como representando Deus no Brasil.

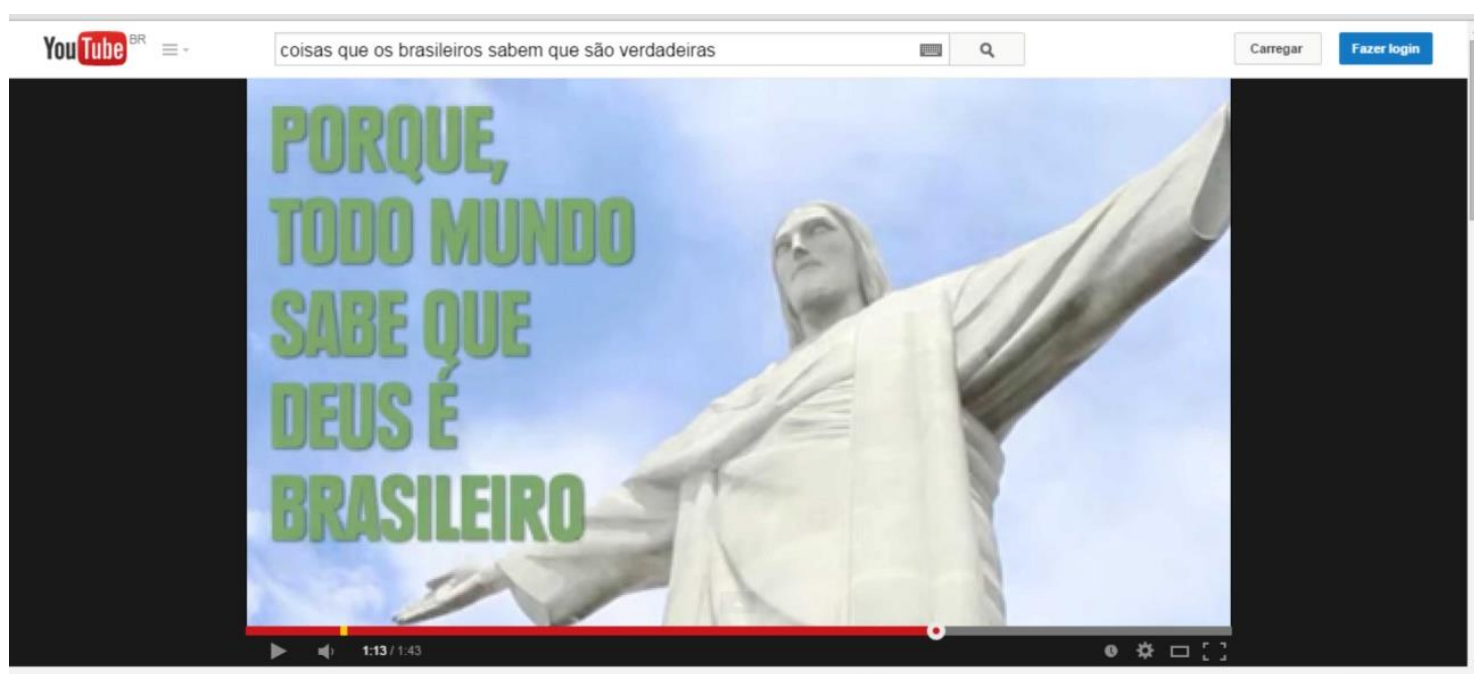

Coisas Que Os Brasileiros Sabem Que São Verdadeiras

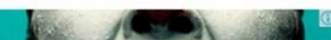

Figura 28: Cristo Redentor

É importante destacar que a análise multimodal aqui empreendida nesta sequência nos traz um caminho de aplicação para os recursos semióticos 
presentes em vídeos online, pois cada um dos quadros é uma amostra representativa sobre potencialidade de significação.

Cada sintagma visual ou verbal ou sonoro atua em conjunto, de maneira a demonstrar que o letramento midiático passa por trabalho didático reflexivo crítico em que o docente não exerce papel passivo, mas atua de maneira consciente sobre quais escolhas são as mais viáveis em tarefas para o ensino de LE. Prosseguiremos então para a próxima seção, que apresenta as considerações finais desta pesquisa. 


\section{CONSIDERAÇÕES FINAIS}

Nesta seção de encerramento da dissertação, retomamos os objetivos e as perguntas que orientaram a pesquisa, buscando respondê-los de acordo com as análises realizadas no capítulo anterior. Em seguida, apresentamos sugestões e possíveis contribuições, práticas, teóricas e metodológicas presentes neste estudo. Fazemos também reconhecimento de limitações e sugestões para pesquisas posteriores.

Nesta pesquisa, partimos da ideia de que há vídeos cujos potenciais multimodais podem viabilizar, enriquecer, motivar e harmonizar o ensino de PLE baseado em tarefas. Buscamos aqui analisar materiais didáticos de ensino de PLE, afim de encontrar momentos para potencial de uso de vídeos online, disponíveis no canal YouTube, para proposta de realização de trabalho estruturado com tarefas no ensino-aprendizagem dessa área.

Este estudo objetivou, inicialmente, investigar, por meio da Multimodalidade, da Abordagem de Ensino Baseada em Tarefas e do Letramento Midiático e Multiletramentos, a operacionalização de vídeos online em unidades de livros didáticos de PLE, de forma a desvelar seus potenciais multimodais para realização de tarefas no ensino-aprendizagem dessa área. Em seguida, vieram as três perguntas de pesquisa. A primeira foi sobre que tipo de vídeos online apresentam condições ideais para operacionalização de tarefas no ensino-aprendizagem de PLE de acordo com os preceitos da Teoria da Multimodalidade. A segunda questionou sobre como situar o trabalho com vídeos online nos momentos de realização da tarefa. A terceira pergunta foi sobre como os recursos semióticos presentes nos vídeos selecionados podem ser contemplados na realização das tarefas para o ensino-aprendizagem de PLE. Iniciaremos, então, revisão de cada uma das perguntas de pesquisa, ressaltando alguns aspectos e conclusões alcançados ao longo do estudo.

Durante o trabalho estruturado no desenvolvimento de tarefas para ensino-aprendizagem de PLE, não houve dificuldades em encontrar vídeos que apresentem condições ideais para operacionalização de tarefas para esse tipo de atividade educacional, pois de maneira geral, basta seguirmos algumas 
observações para realizar o levantamento. Tais observações serão apresentadas à medida que formos respondendo aos questionamentos da pesquisa.

Que tipo de vídeos online apresentam condições ideais para operacionalização de tarefas no ensino-aprendizagem de PLE de acordo com os preceitos da Teoria da Multimodalidade?

Respondendo à primeira pergunta de pesquisa, sobre que tipo de vídeos online apresentam condições ideais para operacionalização de tarefas no ensino-aprendizagem de PLE de acordo com os preceitos da Teoria da Multimodalidade, é necessário que estejamos atentos ao padrão de linguagem verbal, imagética e sonora do vídeo, pois deve ser adequado ao perfil do aprendente que irá realizar a tarefa em sala de aula. São importantes os seguintes aspectos: adequação vocabular ao nível dos alunos, qualidade de som e imagens, duração do vídeo, pois como são apenas parte da aula, e não a aula inteira, não podem ser muito extensos, pois podem fugir do propósito inicial, de dar suporte à aplicação da tarefa. Também, é muito importante que o vídeo tenha conteúdo próximo ao proposto na unidade didática ou na tarefa idealizada pelo professor, caso contrário poderemos incorrer em um dos problemas sinalizados por Morán, sobre os usos inadequados dos vídeos em sala de aula.

\section{Como situar o trabalho com vídeos online nos momentos de realização da tarefa?}

A segunda pergunta de pesquisa questionou sobre como situar o trabalho com vídeos online nos momentos de realização da tarefa. Como mencionamos ao longo do trabalho, temos os três momentos do trabalho com tarefas: o prétarefa, a tarefa em si e o pós-tarefa. Propusemos aqui que no pré-tarefa, que é o momento de introdução ao tópico e à tarefa em si, o professor poderá introduzir o tópico aos alunos, salientar algumas palavras e expressões úteis e em seguida os alunos podem assistir a um vídeo com outras pessoas desempenhando tarefas similares, para que se preparem para o momento da tarefa. Neste 
momento, o vídeo pode figurar como warmup, fazendo com que os alunos iniciem a tarefa motivados pelos potenciais multimodais do vídeo assistido.

\section{Como os recursos semióticos presentes nos vídeos selecionados podem ser contemplados na realização das tarefas para o ensino-aprendizagem de PLE?}

A terceira pergunta foi sobre como os recursos semióticos presentes nos vídeos selecionados podem ser contemplados na realização das tarefas para 0 ensino-aprendizagem de PLE. Façamos aqui uma breve comparação entre trabalho em sala de aula com textos verbais e trabalho com textos multimodais, sobretudo com o recurso do vídeo para compor significações. No trabalho com textos verbais, as possibilidades de leitura são bastante sintéticas, pois o aluno deve se concentrar em leitura de palavras para ir construindo significados. Quando há outras semioses, temos leitura mais complexa, pois o aluno pode realizar a leitura de forma não necessariamente linear, pois quem realiza a relação entre as semioses, a conexão entre o verbal, o imagético e o sonoro é o próprio aprendente. Tais constatações, que foram realizadas pelo emprego das categorias de análise selecionadas, comprovam que existe uma Sintaxe Visual, revelando novas estruturas sintagmáticas, com base na relação entre os elementos imagéticos e sonoros que deve ser considerada no planejamento de tarefas.

Podemos, então, elencar algumas vantagens para ensinar com tarefas ao invés de não o fazer.

- O foco do ensino-aprendizagem não se reduz à forma, estrutura da língua, e sim nos sentidos;

- Não existem respostas certas ou erradas, e sim desenvolvimento ou não da tarefa proposta. Ao final do processo, o próprio aprendente consegue se auto avaliar, de forma que gere reflexões;

- No momento da tarefa em si, os alunos trabalham autonomia, possibilitando que estabeleçam seus próprios caminhos para resolução do que foi proposto, mais semelhante às situações da vida real; 
- Os momentos do trabalho com tarefas (pré-tarefa, tarefa em si e pós tarefa) configuram caminho consistente, limitando improvisos ruins e que o trabalho se perca;

- Uma vez concluída uma tarefa, as outras se tornam mais naturais e o processo fica cada vez mais autoexplicativo, pois há certa recorrência nos comandos das tarefas.

Depois de retomarmos o objetivo inicial do trabalho, as questões de pesquisa e elencarmos possíveis vantagens do trabalho baseado em tarefas, acreditamos que os resultados alcançados aqui podem ser vistos como importante contribuição para $\circ$ trabalho docente. Alertamos aqui sobre mudanças dos modos de significação na sociedade contemporânea, o que requer mudanças paradigmáticas no ensino-aprendizagem de PLE, para que não se volte apenas para o ensino da forma, ou da modalidade verbal, e sim o trabalho com foco nos sentidos, privilegiando o uso de recursos multimodais.

Por fim, reconhecemos ter alcançado aqui apenas começo do que pode vir a ser uma longa caminhada. Trabalhos posteriores podem ser desenvolvidos e aplicados à questão da Multimodalidade em sala de aula de línguas estrangeiras, sobretudo a de PLE, que tanto carece de estudos sistematizados para implementação de novas formas de trabalhar a significação dos discursos. Reconhecemos a grande importância de garantir a adequação da multimodalidade aos diferentes estilos de aprendizagem. Essa foi uma questão que surgiu durante as aplicações teóricas ao trabalho, e que fica como item importante de agendas futuras. Destacamos também a importância de estudos sobre Multimodalidade durante formação inicial e também continuada dos professores que se propõem ao ensino de PLE, para que as práticas sociais envolvidas no processo de ensino-aprendizagem possam ser transformadoras, realizando significações, por parte dos alunos estrangeiros. 


\section{REFERÊNCIAS}

ALMEIDA FILHO, J. C. P. de. Dimensões Comunicativas no Ensino de Línguas. 3. ed. Campinas: Pontes, 2002.

BARBIRATO, R. C. Planejamentos temáticos baseados em tarefas: focalizando a comunicação na sala de aula. In: SILVA, K. A.; ALVAREZ, M. L. O. (Org.). Perspectivas de Investigação em Linguística Aplicada. Campinas: Pontes, 2008, v., p. 359-372.

BAUER, Martin W; GASKELL, George. Pesquisa qualitativa com texto, imagem e som: Um manual prático. Petrópolis: Vozes, 2003.

BEELAND, W. D., Jr. Student Engagement, Visual Learning and Technology: Can Interactive Whiteboards Help? http://chiron.valdosta.edu/are/Artmanscrpt/vol1no1/beeland_am.pdf. 2002 (acessado em 06/11/2014)

BUCKINGHAM, D. The Impact of the Commercial World on Children's Wellbeing. Report of an Independent Assesment for the Department of Children, Schools and Families and the Department of Culture, Media and Sport. Annesley: Department for Children, Schools and Families.http://publications.dcsf.gov.uk/default.aspx?PageFunction1/4productde tails\&PageMode1 publications\&Product1/4DCSF-00669-2009

CHOULIARAKI, L. and FAIRCLOUGH, N. Discourse in Late Modernity: Rethinking Critical Discourse Analysis. Edinburgh: Edinburgh University Press, 1999, p. 224

ELLIS, R. Interpretation tasks for grammar teaching. TESOL Quarterly 29: 87105, 1995.

FERRAZ, J. de A. A formação identitária do brasileiro: um enfoque multimodal. 2005. 105 p. Dissertação (mestrado) - Universidade de Brasília.

A Multimodalidade no Ensino de Português

como Segunda Língua: novas perspectivas discursivas críticas. 2001. 200p. Tese (doutorado) - Universidade de Brasília.

FOSTER, P. \& SKEHAN, P. The influence of source of planning and focus of planning on task-based performance. Language Teaching Research, 3(3), 215-247, 1999.

GIDDENS, A. Modernidade e Identidade. 1.ed. Rio de Janeiro: Zahar Ed., 2002. GUAZINA, L. REVISTA DEBATES, Porto Alegre, v.1, n.1, p. 49-64, jul.-dez. 2007.

HALL, Stuart. A Identidade Cultural na Pós-Modernidade. 11.ed. Rio de Janeiro: DP\&A, 2006. 
HALLIDAY, Michael A. K. An introduction to Functional Grammar. London: Hodder Arnold, 1985.

HOBBS, R. Supporting the development of children's civic engagement: When the teachable moment goes digital and interactive. In P. Verniers (Ed.), Media Literacy in Europe: Controversies, Challenges, Perspectives. EUROMEDUC. European Commission: Brussels, Belgium (p. 97 - 104), 2009.

HODGE, R. and G. KRESS. Social Semiotics. Cambridge: Polity, 1988.

JEWITT, Carey (org.). The Routledge Handbook of Multimodal Analysis. London and New York: Routledge, 2011.

KELLNER, D. Technological Transformation, Multiple Literacies, and the Re-visioning of Education. E-Learning, 1(1): 9 37, 2004.

KELLNER, D.; SHARE, J. Educação para a leitura crítica da mídia, democracia radical e reconstrução da educação. Revista Educação e Sociedade, Campinas, v. 29, n. 104, Especial, p. 687-715, out. 2008.

KLEIMAN, A. Os significados do letramento. Campinas: Mercado de Letras, 1995.

KRESS, G.; LEITE-GARCIA, R. \& VAN LEEUWEN, T. Discourse Semiotics. In: VAN DIJK (ed.). Discourse as Structure and Process: Studies a Multidisciplinary Introduction. Série Discours: Sage Publication, vol 1, pp: 257291. 1997.

KRESS, G. \& Van LEEUWEN, T. Multimodal Discourse: The modes and media of contemporary communication. London: Arnold, 2001.

visual design. $2^{\mathrm{a}}$ ed. London: Routledge, 2006.

Reading images: the grammar of

LIMA, E. E. O. F. (et al) Novo Avenida Brasil 2: curso básico de português para estrangeiros. [Reimpr.]. São Paulo: E.P.U., 2014.

MACHIN, D. and Van LEEUWEN, T. Global Media Discourse. London: Routledge, 2007.

MASTERMAN, L. Media Education: eighteen basic principles. Liverpool University, 1985.

MERKLE, E. R. \& RICHARDSON, R. A. Digital Dating and Virtual Relating: Conceptualizing computer mediated romantic relationships. Family Relations, 49, 187-192, 2000.

MILL, D. Das inovações tecnológicas às inovações pedagógicas: considerações sobre o uso de tecnologias na educação a distância. In:

PIMENTEL, N. (Org.). Educação a distância: desafios contemporâneos. São Carlos: Edufscar, 2010, p. 43-57. 
MORÁN, J. M. Comunicação e Educação, São Paulo, (2): 27 a 35, jan./abr. 1995

NUNAN, D. Task-Based Language Teaching. Cambridge University Press, 2004, 2006.

PALFREY, J.; GASSER, U. Nascidos na era digital: entendendo a primeira geração de nativos digitais. Porto Alegre: Artmed, 2011, 352 p.

PÉREZ TORNEIRO \& VARIS. Media Llteracy and New Humanism. UNESCO Institute for Information Technologies in Education, 2012.

PONCE, M. H. de. Bem Vindo! A língua portuguesa no mundo da comunicação. Maria Harumi de Ponce, Silvia Andrade Burim, Susanna Florissi. 8 ed. São Paulo: Special Book Services Livraria, 2009.

Prabhu, N. S. (1987). Second Language Pedagogy. Oxford University Press. Retrieved 18 January 2013

PRENSKY, M. On the Horizon. MCB University Press, Vol. 9 No. 5, October 2001

Richards, J. C. \& Rodgers, T. Approaches and Methods in Language Teaching (2nd Ed.). Cambridge University Press, 2001.

SANTAELLA, L. Culturas e Artes do Pós-humano. Da Cultura das Mídias à Cibercultura. São Paulo: Paulus, 2003.

L. A Ecologia Pluralista da Comunicação. Conectividade, mobilidade, ubiquidade. São Paulo: Paulus, 2010

Skehan, P. A framework for the implementation of task-based instruction. Applied Linguistics 17: 38-62, 1996.

SOARES, M. Letramento: um tema em três gêneros. 3 ed. Belo Horizonte: Autêntica, 2009

SOARES, Magda. "Letramento e alfabetização: as muitas facetas". Revista Brasileira de Educação, v. 25, p. 5-17, São Paulo, janeiro/abril, 2004

SOARES, T. Videoclipe - O Elogio da Desarmonia. Recife: Livro Rápido, 2004.

TAYLOR, S. J. e ROBERT, B. Introduction to Qualitative Research Methods. USA: New York, 1998.

Van LEEUWEN, T. Introducing social semiotics. London \& New York: Routledge, 2005.

Discourse and Practice: New Tools for Critical Discourse Analysis. New York: Oxford University Press, 2008.

VIEIRA, lúta Lerche. Interação na Internet: novas formas de usar a linguagem / Júlio César Araújo, Bernadete Biasi-Rodrigues (orgs.). - Rio de Janeiro: Lucerna, 2005 
VIEIRA, J. A. et al. Reflexões Sobre a Língua Portuguesa: Uma abordagem multimodal. Petrópolis, RJ: Vozes, 2007.

WALSH, S. Exploring Classroom Discourse: Language in Action, London: Routledge, 2011.

WATKINS \& WILKINS. Using YouTube in the EFL Classroom. Language Education in Asia, Volume 2, Issue 1, 2011

WILLIS, D.; WILLIS, J. Task-based language learning. In: R. Carter; D. Nunan (Eds.). The Cambridge Guide to Teaching English to Speakers of Other Languages. Cambridge: Cambridge University Press, 173-179, 2001.

WILLIS, J. A Framework for Task-Based Learning, Harlow, UK: Longman Addison- Wesley, 1996.

YOUNG, J. S. Linking learning: connecting traditional and media literacies in 21 st Century Learning. Journal of Media Literacy Education, v. 4, n. 1, p. $70-$ 81, Montclair, 2012.

\section{Jornais}

Correio Braziliense

http://www.correiobraziliense.com.br/app/noticia/cidades/2013/06/03/interna_cidadesdf,369221/ uso-de-tablets-em-escolas-tem-impacto-timido-no-desempenho-de-alunos.shtml. Acesso em 07/01/2015

\section{Websites}

Live Web Art: laboratório de mídias instáveis. www.memelab.com.br (acesso: 02/11/2014)

Brasil Escola. http://www.brasilescola.com/historia/sputnik.htm (acesso: 15/01/15)

Info Escola: navegando e aprendendo. http://www.infoescola.com/estadosunidos/pentagono-eua/ (acesso: 15/01/15)

Glossários de termos de edição.

http://www.letras.ufmg.br/vivavoz/data1/arquivos/glossario-site.pdf (Acesso: 16/01/2015)

\section{Vídeos - Youtube}

Buzz Feed Vídeos. Coisas que os brasileiros sabem que são verdadeiras, 2013.

https://www.youtube.com/watch?v=Kd-sOVHWgpA (acesso: 17/01/2015)

COSTA, Pedro. Minutos Psíquicos: preconceito e estereótipo, 2014.

https://www.youtube.com/watch?v=7m-yuzFlipc (acesso: 17/01/2015)

CVC Viagens. Porto de Galinhas - CVC Viagens, 2008.

https://www.youtube.com/watch?v=01frfxRmfWk (acesso: 17/01/2015) 
ANEXOS 


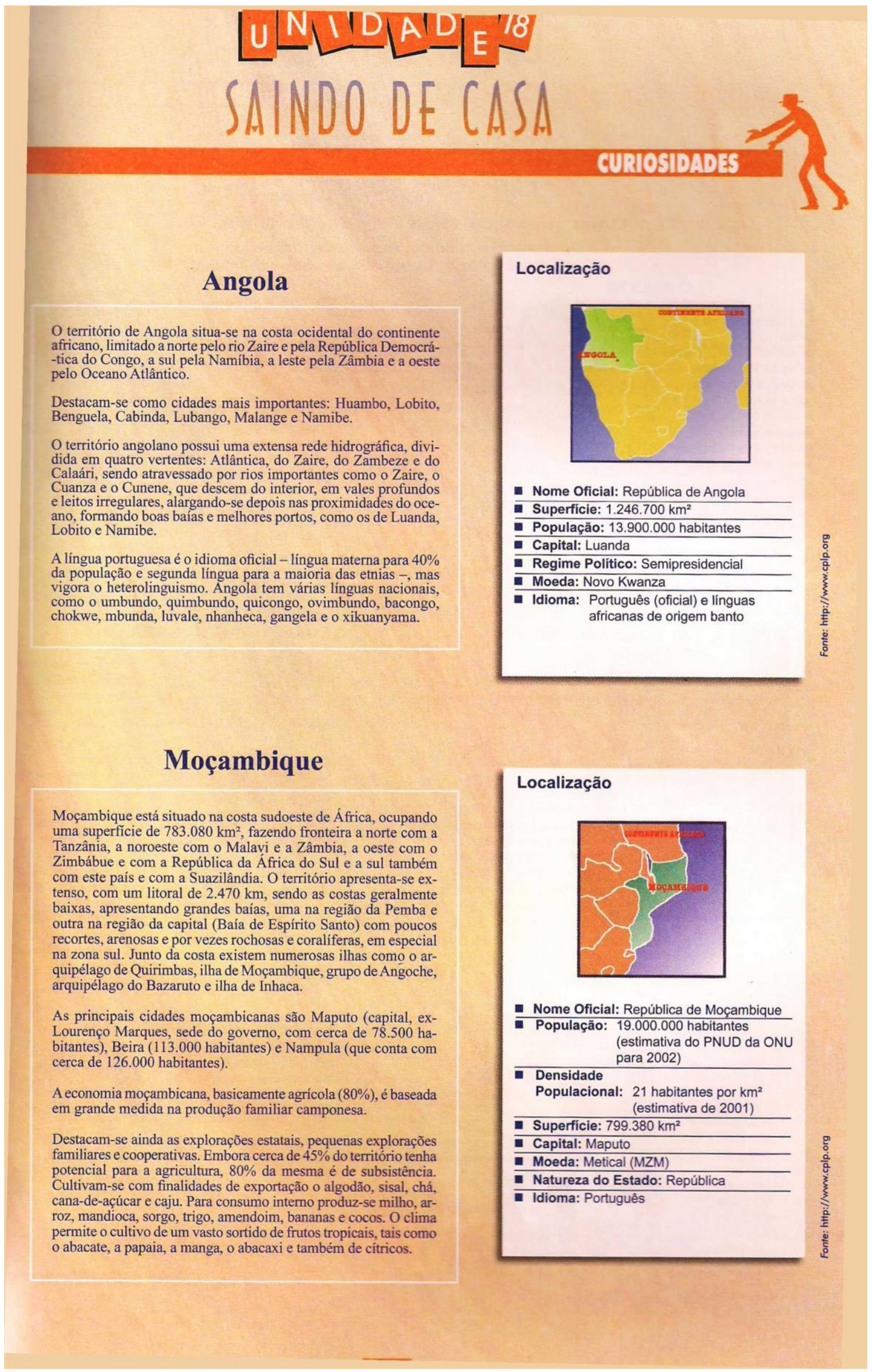




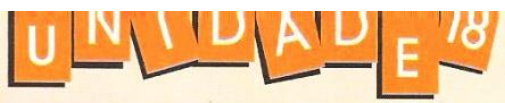

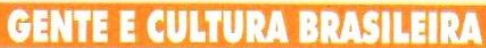

\author{
QUEM SOMOS, AFINAL? (2)
}

Outros personagens típicos entre o povo brasileiro são:

\begin{abstract}
É a mestiçagem mais comum no Brasil, fruto do cruzamento entre brancos e negros. No período colonial, o mulato era quase sempre a prova do abuso do senhor de engenho, que escolhia na senzala as mulheres negras mais bonitas para sua satisfação sexual. Hoje, o mulato é um símbolo da beleza brasileira cada vez
\end{abstract}

O MULATO mais numeroso.
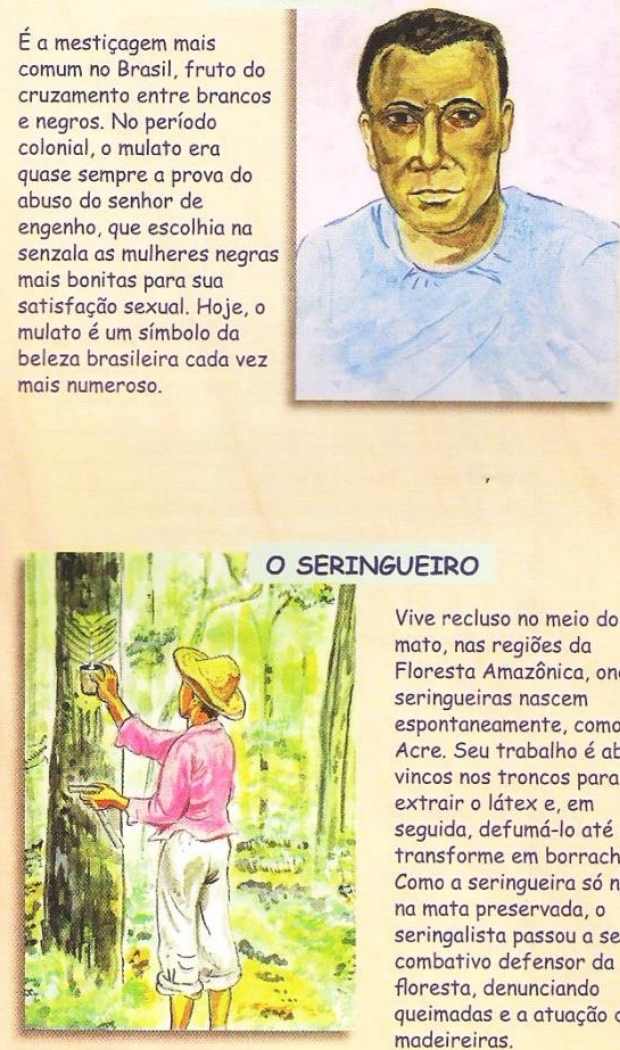

Vive recluso no meio do mato, nas regiões da Floresta Amazônica, onde as seringueiras nascem espontaneamente, como no Acre. Seu trabalho é abrir vincos nos troncos pare extrair o látex e, em seguida, defumá-lo até que se transforme em borracha. Como a seringueira só nasce na mata preservada, 0 seringalista passou a ser um combativo defensor do floresta, denunciando queimadas e a atuação de madeireiras.

$$
\text { स्थ }
$$ \\ O JANGADEIRO}

É o pescador dos mares nordestinos, que vive nas comunidades do litoral. Especializou-se na pesca de rede a bordo de jangadas, pequenas embarcações de vela triangular feitas de seis paus roliços retirados das matas da região. Singrando as águas verdes e ensolaradas, no amanhecer ou no pôr-do-sol, o jangadeiro virou elemento típico da paisagem da região $e$ símbolo de Alagoas.

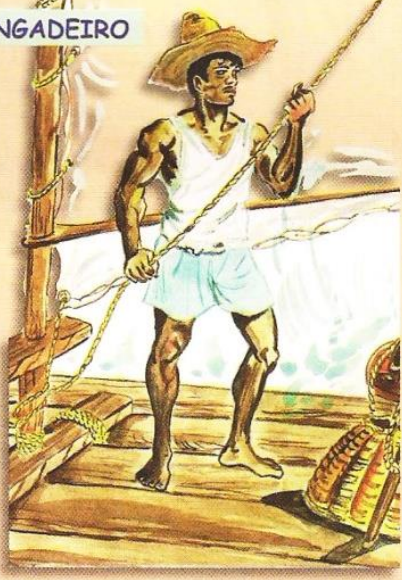

\section{O PANTANEIRO}

O homem pantaneiro, que é basicamente um

vaqueiro adaptado para as pastagens úmidas, nasceu com a chegada da criação extensiva de gado ao Pantanal. O sistema de cheias e vazantes do rio Paraguai obriga o

constante deslocamento dos rebanhos das terras baixas e alagáveis para as altas e secas. Ao

contrário do gaúcho, que só come carne, 0 pantaneiro também aprecia a fartura de peix da região.
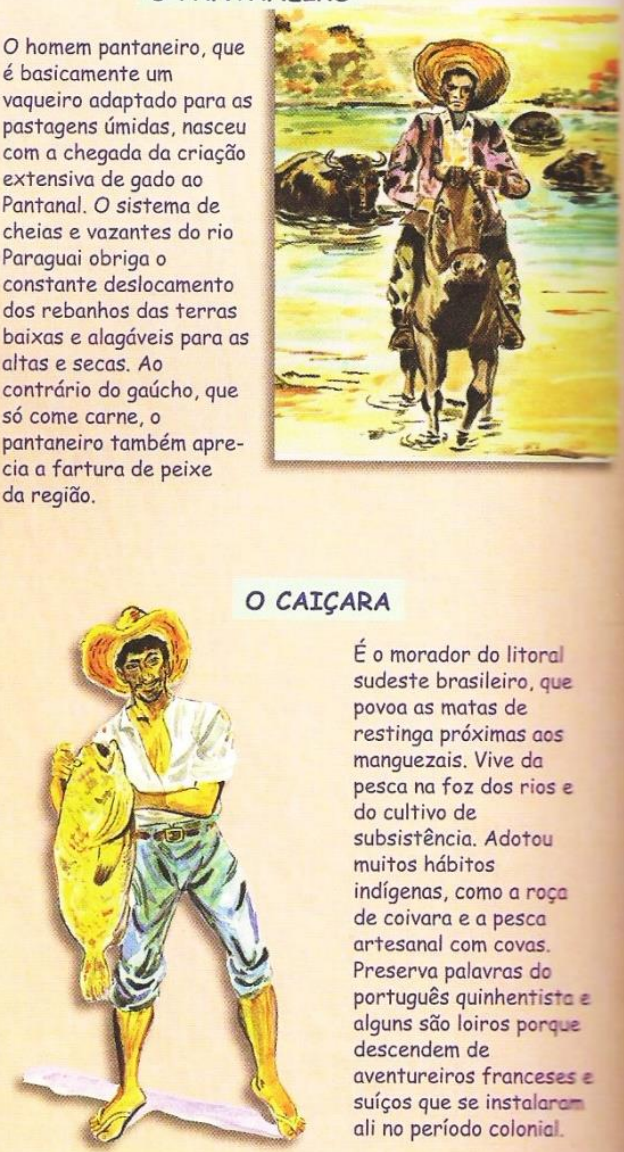

É o morador do litoral sudeste brasileiro, que povoa as matas de restinga próximas aos manguezais. Vive da pesca na foz dos riose do cultivo de subsistência. Adotou muitos hábitos indígenas, como a roça de coivara e a pesca artesanal com covas. Preserva palavras do português quinhentista alguns são loiros porque descendem de aventureiros franceses suíços que se instalarom ali no período colonial.

\section{O MESTIÇO \\ ORIENTAL}

$O$ termo mestiço serve para definir qualquer tipo de mistura de raças, mas nos últimos anos tem sido mais usado para o caso dos orientais. O fenômeno ainda é recente e em certa medida, raro, pois a raça amarela - da qual os japoneses são maiori no Brasil - viveu décadas organizada em colônios

fechadas, o que

dificultou a mistura.

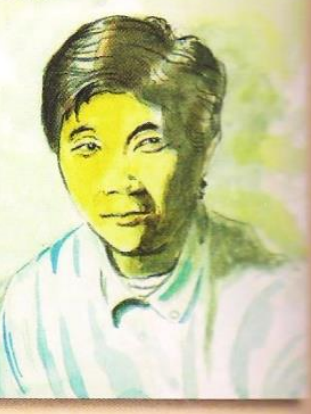




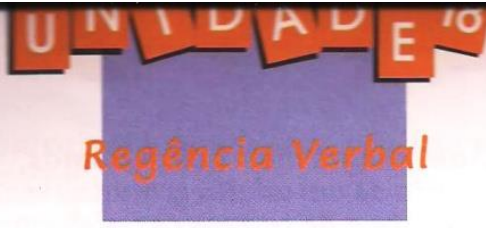

\section{- MUNDO NAS COSTAS}

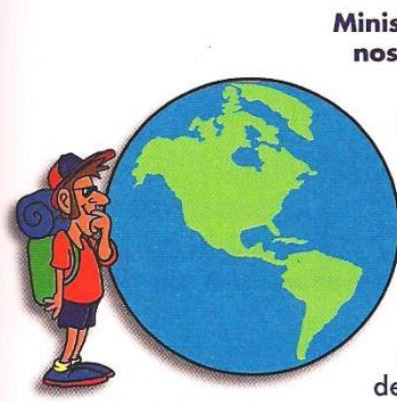

Ministério do Turismo quer aumentar hospedagem

nos albergues do país incentivando mochileiros

Nada de carregador de malas, hotel bacana, fartos cafés da manhã ou

almoços em restaurantes de renome. A ideia é conhecer lugares e culturas diferentes de forma mais descontraída e econômica. Essa é a regra número um de quem decide colocar tudo dentro de uma mochila e sair por aí. De olho nesse tipo de viajante, que em sua maioria tem entre 20 e 30 anos, o Ministério do Turismo vai apoiar uma campanha de incentivo aos mochileiros criada pela Federação Brasileira de Albergues da Juventude. A federação, por sua vez, pretende ampliar a rede de hospedagem no país para ver o número de usuários anuais pular de 100 mil para 500 mil no curto prazo. "Queremos ter estabelecimentos para esse público em todos os Estados e criar essa cultura de viagem na cabeça dos brasileiros", afirma José Roberto de Oliveira, da Secretaria Nacional de Políticas do Turismo.

Fonte: Texto adaptado de artigo da revista Época - 2004

E você? Alguma vez passou pela experiência de fazer uma viagem com a mochila nas costas? Caso tenha feito várias viagens assim, qual foi a sua favorita? Por quê? No seu país existem muitos Albergues da Juventude? São bem localizados? São muito utilizados? Por quê?

Além dos já mencionados no texto acima, liste os prós e os contras de se viajar

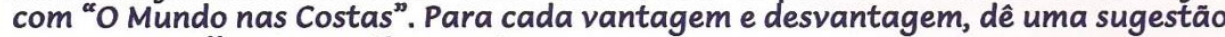
ou um conselho, respectivamente.

EXEMPLO: 1. Quando viajamos sem malas nos deslocamos com mais facilidade. (pró) Sugestão: Ao viajar com uma mochila, escolha fazê-lo de trem.

1. Em uma mochila não cabem muitos pares de sapatos. (contra) Conselho: Procure sempre levar pelo menos um par de sandálias.
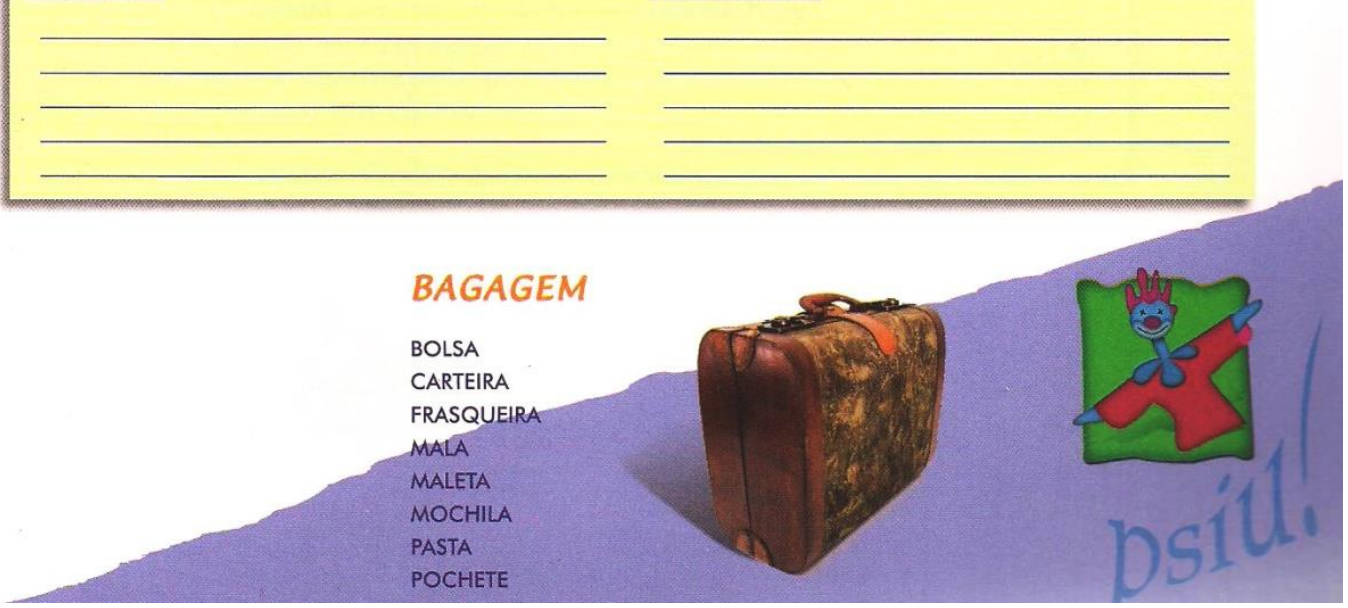


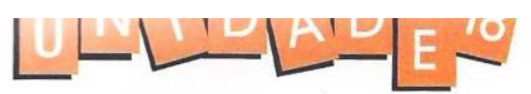

Dizem alguns psicólogos que, ao chegarmos aos 42 anos, voltamos à energia da adolescência, mas com o conhecimento de um adulto e, muitas vezes, com a possibilidade de sermos independentes financeiramente e de termos certa disponibilidade de tempo para gozarmos mais nossas vidas.

Caso você já tenha passado dos 42 anos e queira confessá-lo, diga se concorda com a constatação acima. Caso concorde, responda:

1. Quais das atividades listadas em seguida o atraem mais? Apresente suas razões para a escolha.

- Reunir-se com amigos para cozinhar na casa uns dos outros.

- Frequentar bares.

- Praticar esportes radicais.

- Ir a shows de música popular.

- Viajar para lugares inusitados.

2. Que atividades consideradas "para velhos" antes de você chegar aos 42 hoje o atraem sem que, por isso, se considere "de idade"?

3. Pessoas acima dos 42 anos passaram por épocas revolucionárias marcantes: o movimento hippie, a revolução sexual, os movimentos feministas, etc. Como você acha que essas vivências influenciaram seu modo de vida atual?

Caso você ainda esteja longe dos 42 anos, como imagina que será sua assim chamada "meia-idade" ou até a sua "terceira idade"? Você tem algum receio? Como você está se preparando física e mentalmente para essa fase?

Em nota sobre o mundo diplomático, a revista Época, em sua edição de número 304, fez a seguinte constatação:

"Não é à toa que o lłamaraty quer estimular os diplomatas que se dispuserem a dar expediente em embaixadas distantes do circuito Elizabeth Arden. Em Pequim há 12 vagas, mas só a metade está ocupada. Em Nova Délhi trabalham apenas dois dos oito diplomatas previstos. Já em Paris, os 18 postos, incluindo os quatro da representação do Brasil na Unesco, estão sempre preenchidos. E com fila de interessados."

Sem fazer uso do dicionário e, baseando-se no texto acima, tente definir:

$\begin{array}{ll}\text { 1. à toa } & \text { 6. apenas } \\ \text { 2. dispuserem } & \text { 7. já } \\ \text { 3. dar expediente } & \text { 8. representação (na Unesco) } \\ \text { 4. circuito Elizabeth Arden } & \text { 9. preenchidos } \\ \text { 5. há } & \text { 10. fila }\end{array}$

Ouça o áudio e descubra qual o lugar ideal para passar as férias mencionado por cada um dos personagens e o motivo da preferência.

\begin{tabular}{|l|l|l|}
\hline & Descrição do lugar ideal & Motivo \\
\hline $\begin{array}{l}\text { Manuel } \\
\text { Dálton } \\
\text { Celina } \\
\text { Kátia }\end{array}$ & & \\
\hline
\end{tabular}

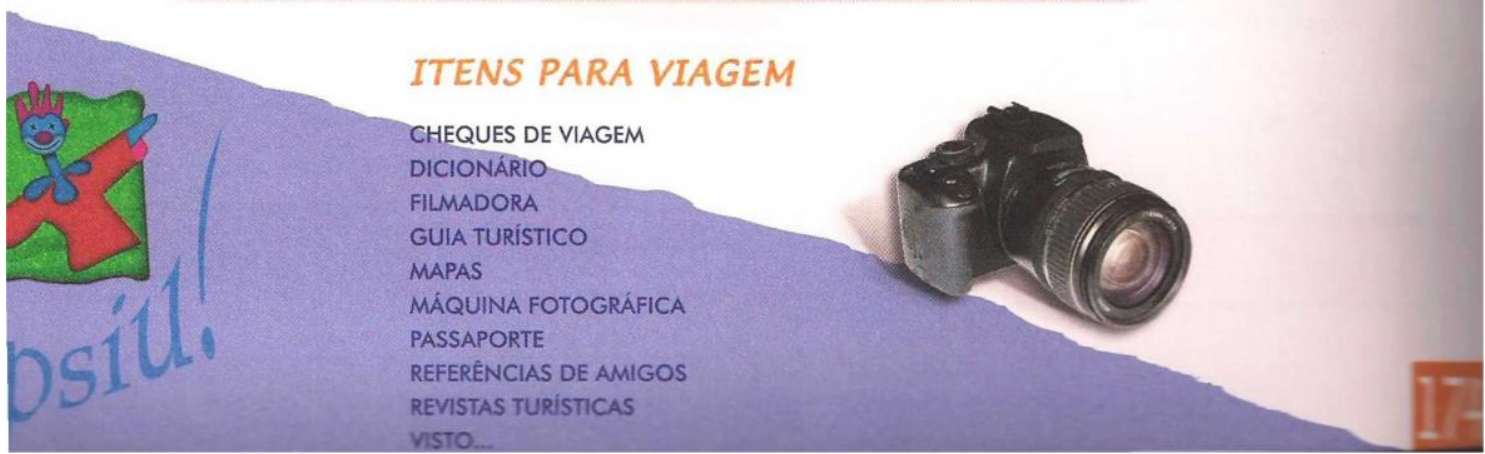




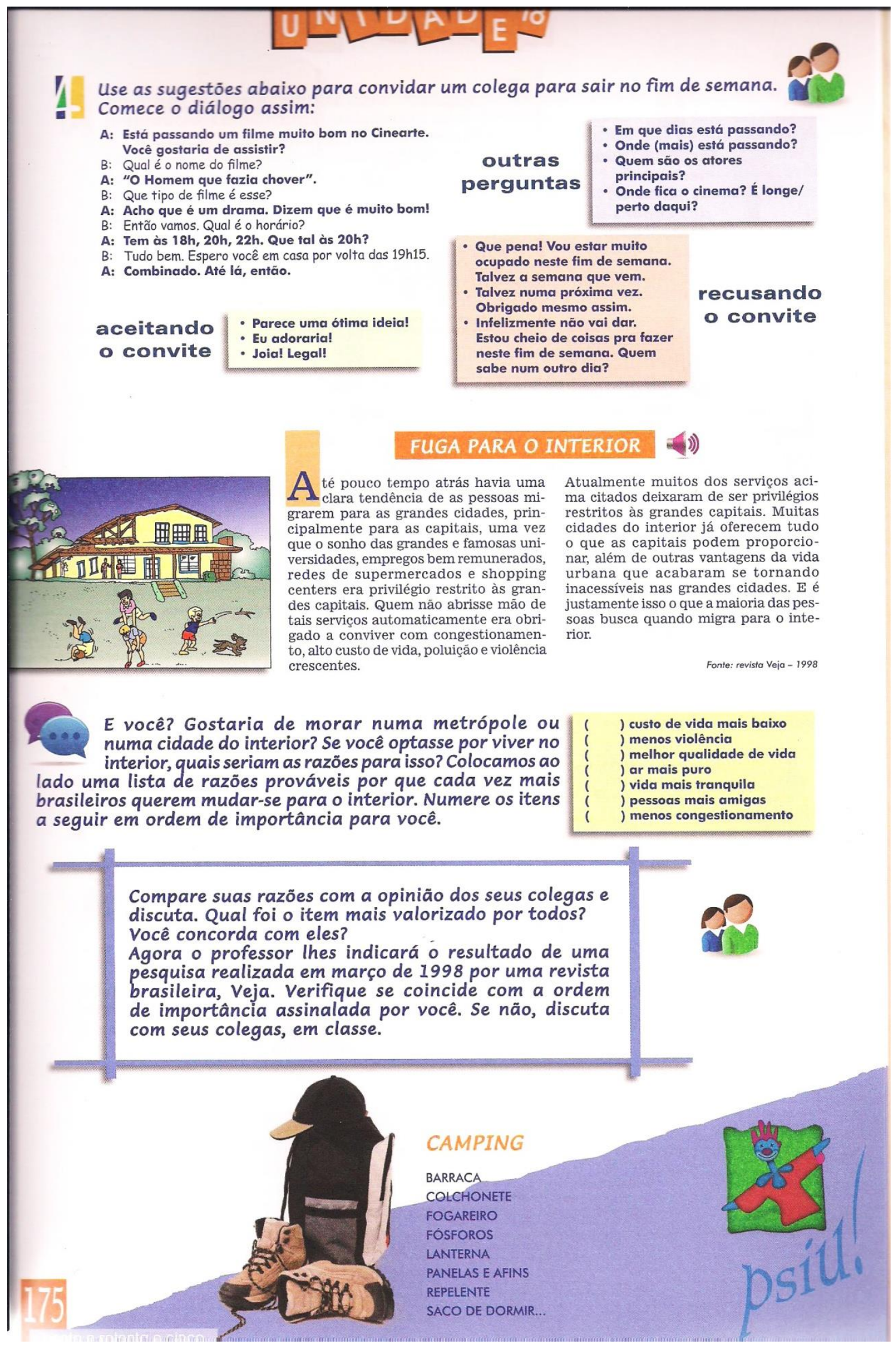




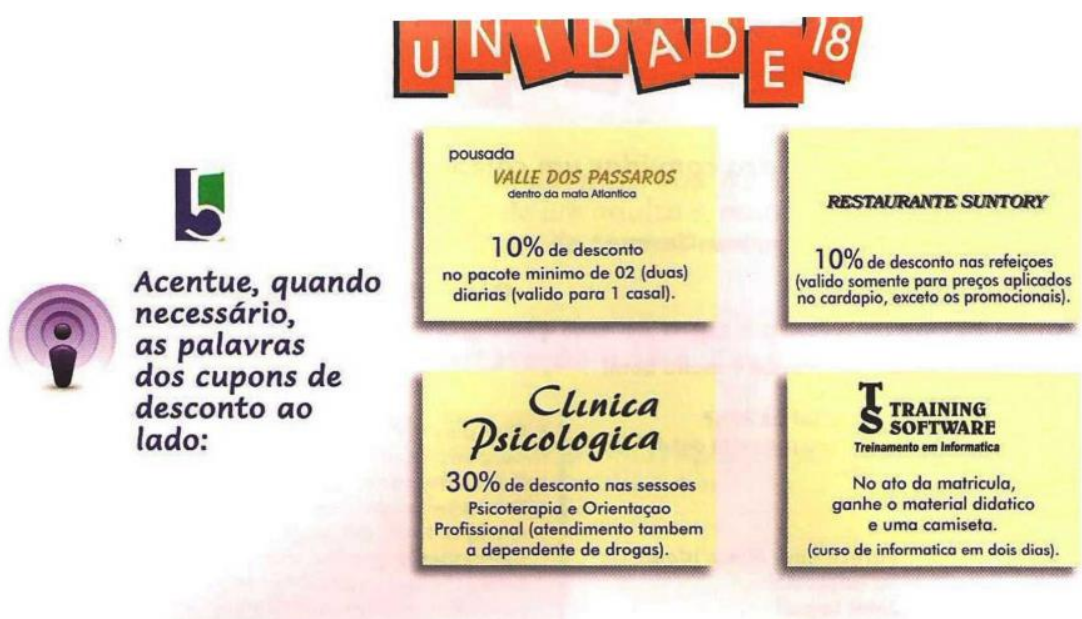

Que profissionais estão relacionados às propagandas acima? EXEMPLO: 1 - Pousada Valle dos Pássaros: arrumadeira, porteiro, ...

No Brasil o valor das multas muda de acordo com o tipo de infração.

Use a lógica para unir as colunas abaixo.

Infração de natureza gravíssima: 180 UFIR

(7 pontos)

Infração de natureza grave: 120 UFIR

(5 pontos)

Infração de natureza média: 80 UFIR

(4 pontos)

Infração de natureza leve: 50 UFIR

(3 pontos)
- Dirigir veículo sem possuir Carteira Nacional de Habilitação.

- Ter seu veículo imobilizado na via por falta de combustível.

- Estacionar o veículo afastado da guia da calçada

(meio-fio) de cinquenta centímetros a um metro.

- Transitar em marcha a ré, salvo na distância necessária a pequenas manobras e de forma a não causar riscos à segurança.

\section{VIAJE $\mathrm{CU}$ C \\ APROVIITE A PROMOSÁO \\ - PORTO SECURO $\sqrt{ } \mathbf{B 1 8 , 0 0}$

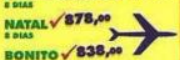 \\ - \\ EAgA JA A SUA RESERVA \\ Iir 231-1222}

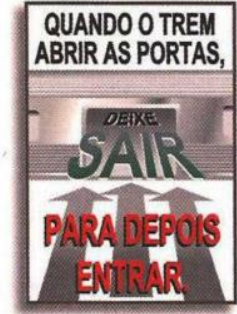
Observe os seguintes folhetos
informativos e publicitários. O
que eles têm em comum é o tempo verbal: O IMPERATIVO. Por que será que os especialistas em publicidade usam tanto o Imperativo? Pesquise e discuta com seu colega/professor.

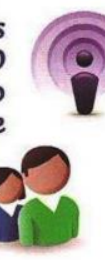

Agora vamos criar um folheto informativo para uma agência de viagens a fim de fazer propaganda do seu país, da sua beleza, da sua cultura. Deve ser o mais atraente, convidativo e convincente possível. Use e abuse do IMPERATIVOI Coloque também um título sugestivo para o folheto.

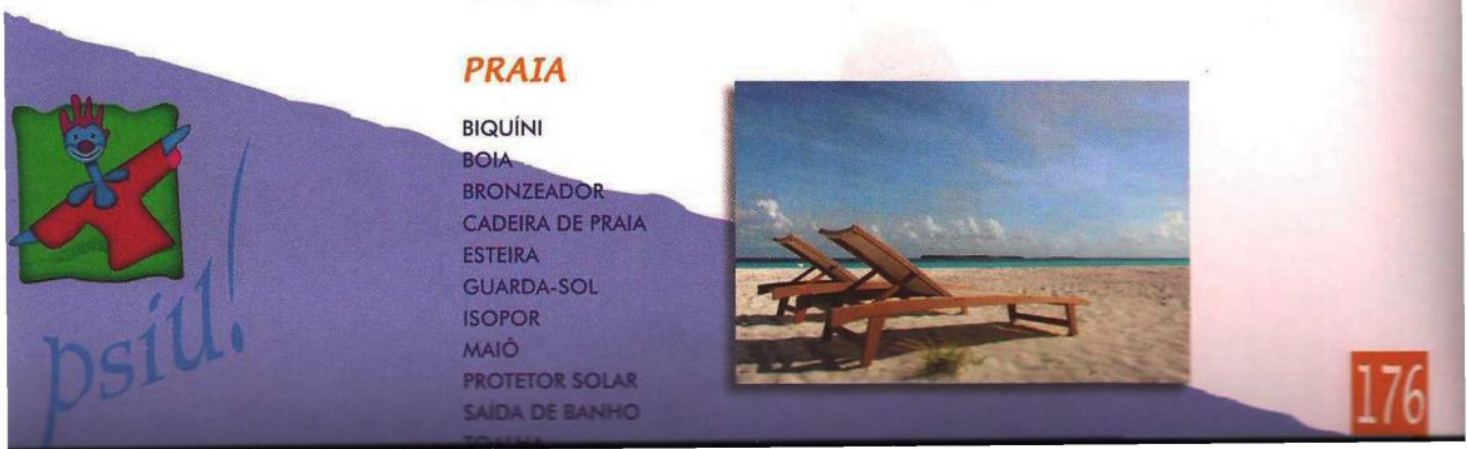


No Brasil, o termo "sair de casa" está por vezes associado ao casamento. Alguns preparativos importantes acontecem quando nos preparamos para essa cerimốnia. A Fundação Procon, vinculada à Secretaria de Justiça e Defesa da Cidadania do Estado de S. Paulo, preparou um guia para orientar noivos e noivas. 0 jornal 0 Estado de Säo Paulo publicou-o no mês das noivas de 2004. Que cuidados você acha que o Procon sugeriu em seu guia para os itens abaixo? Confira suas respostas com o seu professor.

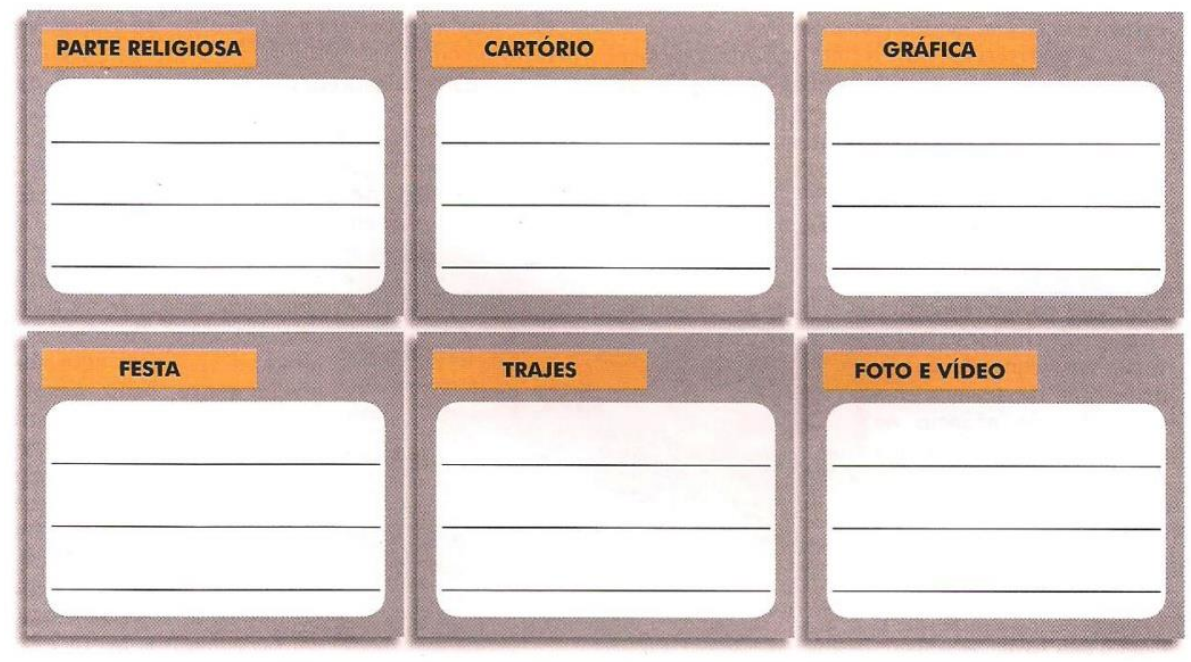

Alguns verbos pedem o uso de uma preposição que pode inclusive modificar seu significado. Discuta a diferença de sentido entre as frases abaixo:

1. Sempre agrada o filho quando o vê. 2. Sentiu-se mal ao aspirar a fumaça.

3. Por que você implica tanto com ele?

4. Quero o bem-estar de todos.

5. As enfermiras assistem os idosos com carinho $\neq$

6. Custou-me encontrar uma boa casa

7. Vim de metrô para a escola.

8. Eles falam da fome.

9. Eu o encontrei no vilarejo.

10. Cheguei à casa do produtor.

O presente não agradou ao filho.

Aspiramos a um cargo melhor.

Exigir os seus direitos implica altos riscos. Quero a todos por igual.

Quero a todos por igual. As enfermeiras assistem ao jogo de tênis. Esse é um direito que lhe assiste.

$O$ carro the custou barato.

Vim do Metrô para a escola, correndo.

Enquanto isso milhares morrem de fome.

Eu o encontrei num vilarejo.

Cheguei da casa do produtor.

\section{Acrescente uma preposição a cada uma das frases seguintes:}

1. O filme que assisti me deixou muito emocionada.

2. A única pessoa quem confio é você.

3. O cão obedece o dono cegamente.

4. Nós aspiramos um mundo melhor
. A loja que entrei ontem estava fazendo liquidação de quase todos os produtos.

6. O cantor não agradou os fãs.

7. Os lugares onde fui são estes.

8. Amélia náo simpatiza Haroldo.

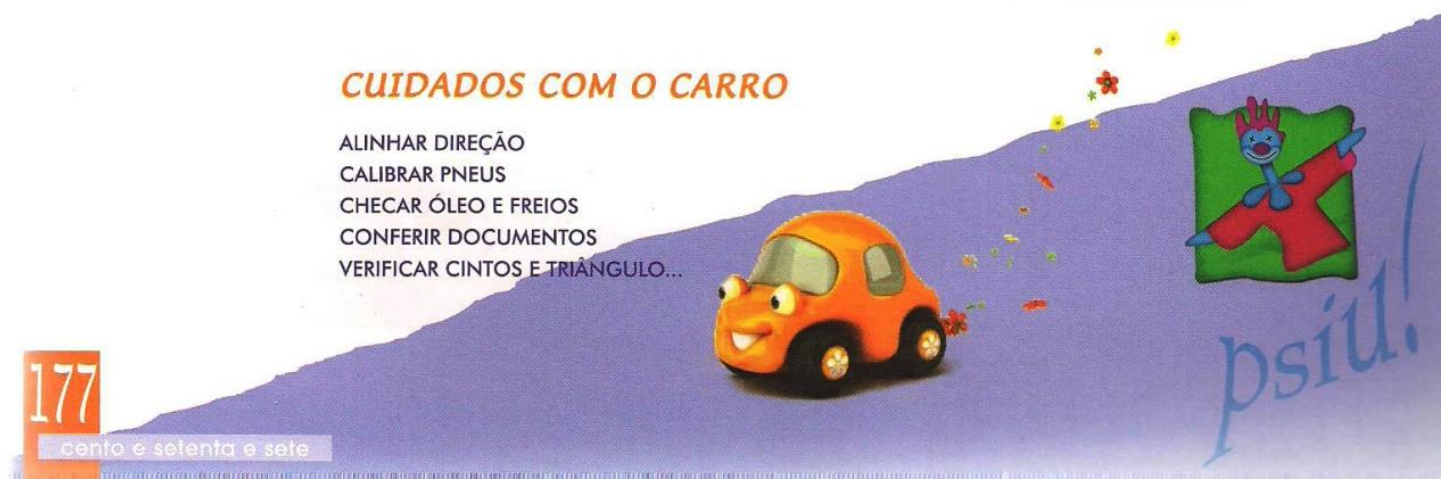




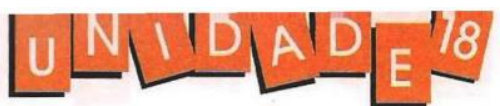

II

Leia o texto abaixo $e$ :

1. pesquise o significado das palavras sublinhadas no texto

2. circule a preposiçáo correta que aparece entre parênteses no texto.

\section{Mulher na Pesca - Que emoção lúdica!}

Quando eu ouvia comentários a respeito de pesca, normalmente masculinos, o que imaginava eram paisagens bucólicas onde um homem calmamente sentado à beira do rio esperava sua presa. Mas onde estava a ação que muitos comentavam?

A pesca parecia, até então, uma atividade sem muita emoção, onde para justificar sua prática se inventavam histórias. Eu acreditava que pessoas ativas e "plugadas" nos roteiros alternativos e culturais de uma cidade como São Paulo não se interessariam por esse esporte.

Conforme ouvia de amigos, a pescaria também era utilizada para se criarem álibis, justificando eventuais férias conjugais. Numa destas histórias, aconteceu um flagra. Ao voltar de um fim de semana com os amigos de infância, no canal de Bertioga, quando a aventura tinha acontecido nas areias da praia e não em alto-mar, um dos mentirosos pescadores se esqueceu (em, de, para) trazer alguns exemplares que testemunhariam a seu favor. A solução

foi comprar peixes de pescadores nativos. Porém encontrou em uma peixaria o peixe já limpo e embalado. Sua esposa logo o desmascarou, quando ao preparar o peixe encontrou um carimbo azul de fiscalização em seu dorso. Logo pensei: pescador necessita mesmo inventar histórias para proporcionar emo ção a seus ouvintes.

Foi então que em uma viagem de reveillon com minha paixão descobri a emoção da pesca. $\mathrm{Na}$ Ilha do Cardoso eu, meu leonino e toda aquela tralha de varas, alicates, molinetes, puçás...

$E$, acima de todos os meus preconceitos sobre a arte de pegar aqueles bichinhos que respiram por brânquias, me lambuzei de citronela, contra as mutucas, e embarquei logo cedo naquele barco de alumínio. Até então não conhecia de perto as habilidades de pescador de meu namorado, mas depois de preparar uma vara com a linha passando através dos anéis, o chumbo, o chicote e depois o anzol, ele me convenceu. Sorrindo, disse: "Esta é para você. Pega um camarão vivo e vem aqui que eu vou te ensinar (para, a) arremessar".

Arremessar, mas o quê? Como? Seu sorriso me fez entender a paz contida em um canal de ilha, cheio de vegetação, céu azul e águas límpidas, onde arremessei pela primeira vez.

Como dizia o filósofo: "Amo aquele que não quer ter muitas virtudes. Uma virtude é mais do que duas, porque tem mais nó a que se suspender a fatalidade". fisgada.

E, fatalmente, o meu primeiro sinal de

Senti meu batimento cardíaco se precipitar, tendo que segurar forte com a segunda fisgada. Um certo medo de deixar escapar de minhas próprias mãos essa emoção também me atingiu.

Novamente, com meiguice a resposta: "Sente. com calma fisgue forte $e$ de uma vez, puxa. Puxa para 0 alto e vai enrolando esta manivela, sente, solta, enrola mais a linha, com firmeza cede e continua enrolando". E toda a minha energia voltou-se (a, para, com) a água e dentro dela vi uma luzinha prateada e saltitante.

Era meu primeiro Robalinho na Ilha do Cardoso. em Cananeia, tão perto e a mesmo tempo distante de meu hábitat urbano $e$ natural. Ah, que emocão lúdica é se sentir incapaz, por uma fração de segundos, de controlar sua própria emoção.

Então gritei de felicidade e beijei aquele exemplar escorregadio que veio de dentro das águas, sentindo sua força por entre meus dedos.

Por todo o dia fiquei pescando e apostando quem pegava mais peixes. Como todo pescador sabe, naturalmente, fui eu quem mais pescou naquele dia, sorte de principiante.

"Amo aqueles que não procuram atrás das estrelas uma razão para sucumbir e serem sacrificados: mas que se sacrificam à terra...", aos peixes, às águas, a varas, puçás e outros objetos pelo puro prazer da pesca, que passa de pai para filho, de avô para neto, de marido para mulher.

Agradeço (para, ao, a) avô Roque, hoje avô do meu marido por um dia tê-lo levado ao "Morro do Maluf" para pescar no fim da década de 1970. Assim os homens passam como espíritos (pela, por) sobre a ponte e cheios de emoção pescam: Robalos, Pernas-de-Moça, Bagres, Baiacus e criam os valores em que acreditam: na pescal

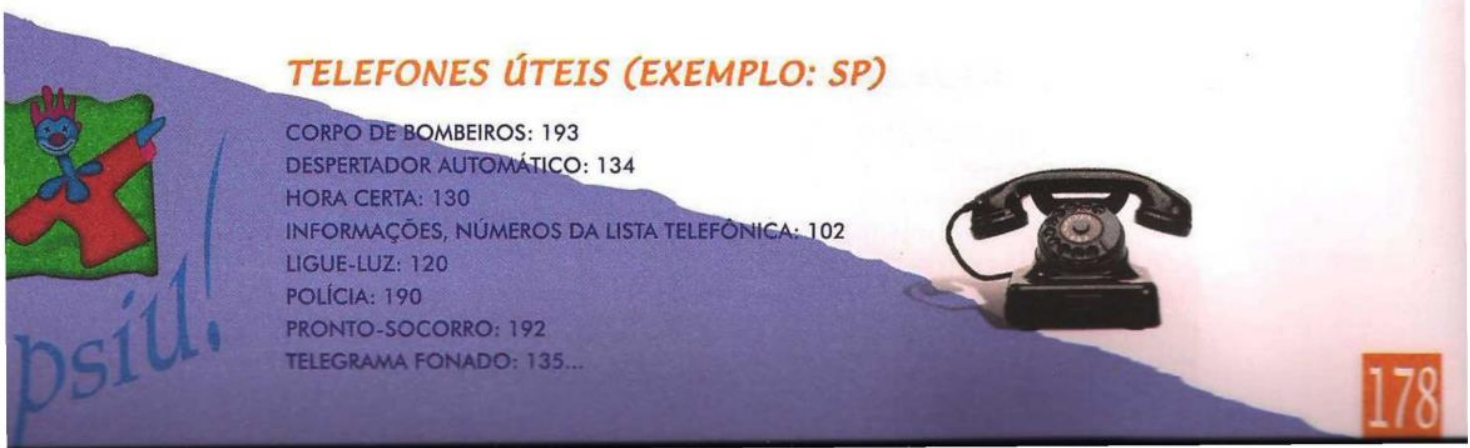




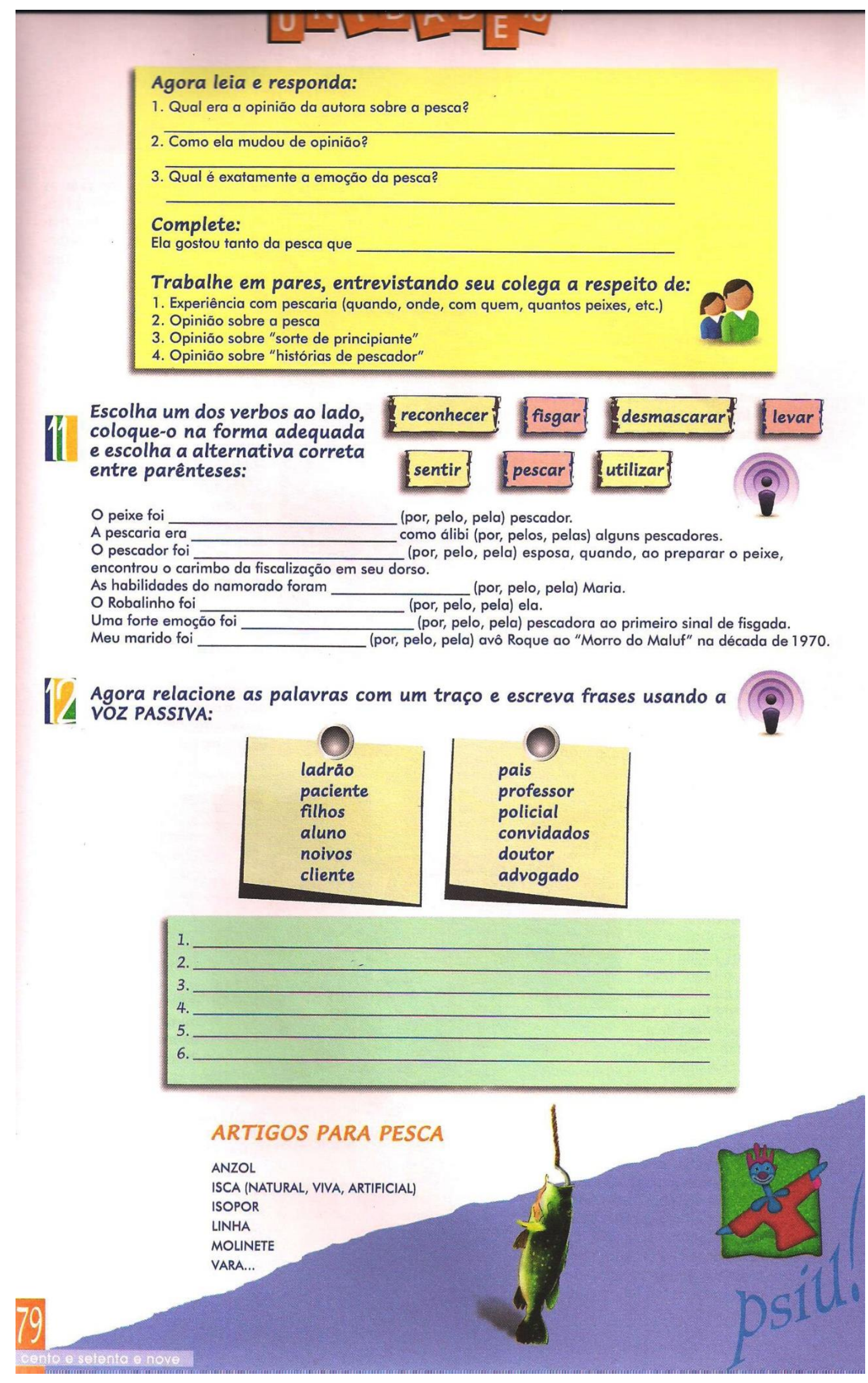




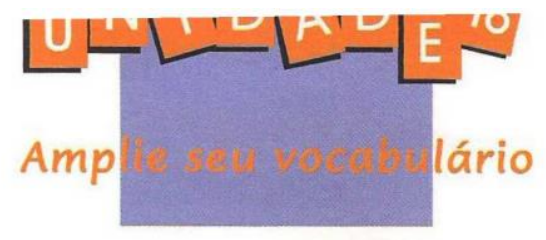

Para a maior parte das pessoas, as férias ideais são passar uma semana na praia a fim de descansar do trabalho e voltar com um bronzeado de abafar. Mas o que acontece quando o casal leva as crianças?

Bem, por certo não vai ser possível ter muitos momentos íntimos, tirar boas sonecas nem ficar bebendo até tarde da noite. Então por que fazemos o impossível para encaixar as crianças quando planejamos férias? Quem sabe porque todos necessitamos dar atenção aos filhos e, como pais ocupados, não conseguimos isso na correria do dia-a-dia. Alguns amigos meus tratam de dar essa atenção às crianças viajando todo santo ano para Orlando a fim de visitar a Disney pela enésima vez - junto com hordas de crianças brasileiras em férias escolares - numa tentativa de aplacar o sentimento de culpa e agradar aos filhos. Eu não consigo ter tanta abnegação!

Afinal, fora a Disney existem muitos outros lugares onde

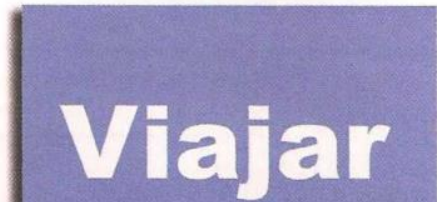

berço, etc. quando comprar as passagens. Leve um kit de sobrevivência completo - fraldas, mamadeiras, leite já medido, babadores, lanchinhos, uma muda de roupa, o brinquedo favorito. Crianças maiores gostam de levar a mochila delas cheia de brinquedos e outros objetos para atividades. Quanto a crianças de peito, dê-lhes de mamar na hora da decolagem e do pouso, para aliviar a pressão nos ouvidos delas. Às crianças maiores, dê chupetas, doces ou bebidas para obter o mesmo efeito.

Leia tudo que puder sobre o lugar para onde vai e verifique com todo cuidado as coisas especiais de que vai precisar, como berços, cadeirinhas para adaptar nos assentos do automóvel, quartos com varanda - ótimos para secar roupa e jantar a dois depois que as crianças dormirem. Calcule quantos fusos horários vocês vão atravessar para encaixar as crianças suavemente numa rotina razoável. Procure não reservar nada sem informações confiáveis - os folhetos turísticos são passar as férias com a família que tal Marrocos, Espanha, França, Escócia, Estados Unidos, Grécia e, é claro, as belas praias do Brasil? Passamos férias maravilhosas em todos esses lugares, muitas vezes sem que houvesse atividades ou diversões especialmente destinadas aos "baixinhos".

O grande segredo do sucesso das férias com a família é o planejamento. Se for viajar para o exterior, pesquise detaIhadamente as opções de voo. Viagens longas de avião levando crianças sempre são melhores à noite, horário que facilita o sono. Escolha um voo direto, sem escalas, e procure reservar assentos na frente, além de enfamosos por mentir ou enfeitar a realida de. Um exemplo é a ilha de Santorini, onde estivemos há uns dois anos: os lindos quartos-caverna do apart-hotel, reservados por um amigo solteiro e sem filhos, eram perfeitos - se não considerarmos que para chegar lá tínhamos que descer pelo menos 200 degraus bem inclinados. Depois de uma semana e sabe

Deus quantas subidas $e$ descidas com duas crianças pequenas, carrinhos e mochilas, estávamos em condições de correr uma maratona!

$\mathrm{O}$ verdadeiro segredo, no entanto, é de vez em quando tirar umas férias sem as crianças - vocês vão sentir uma falta tremenda delas, mas vão adorar aqueles momentos íntimos! 


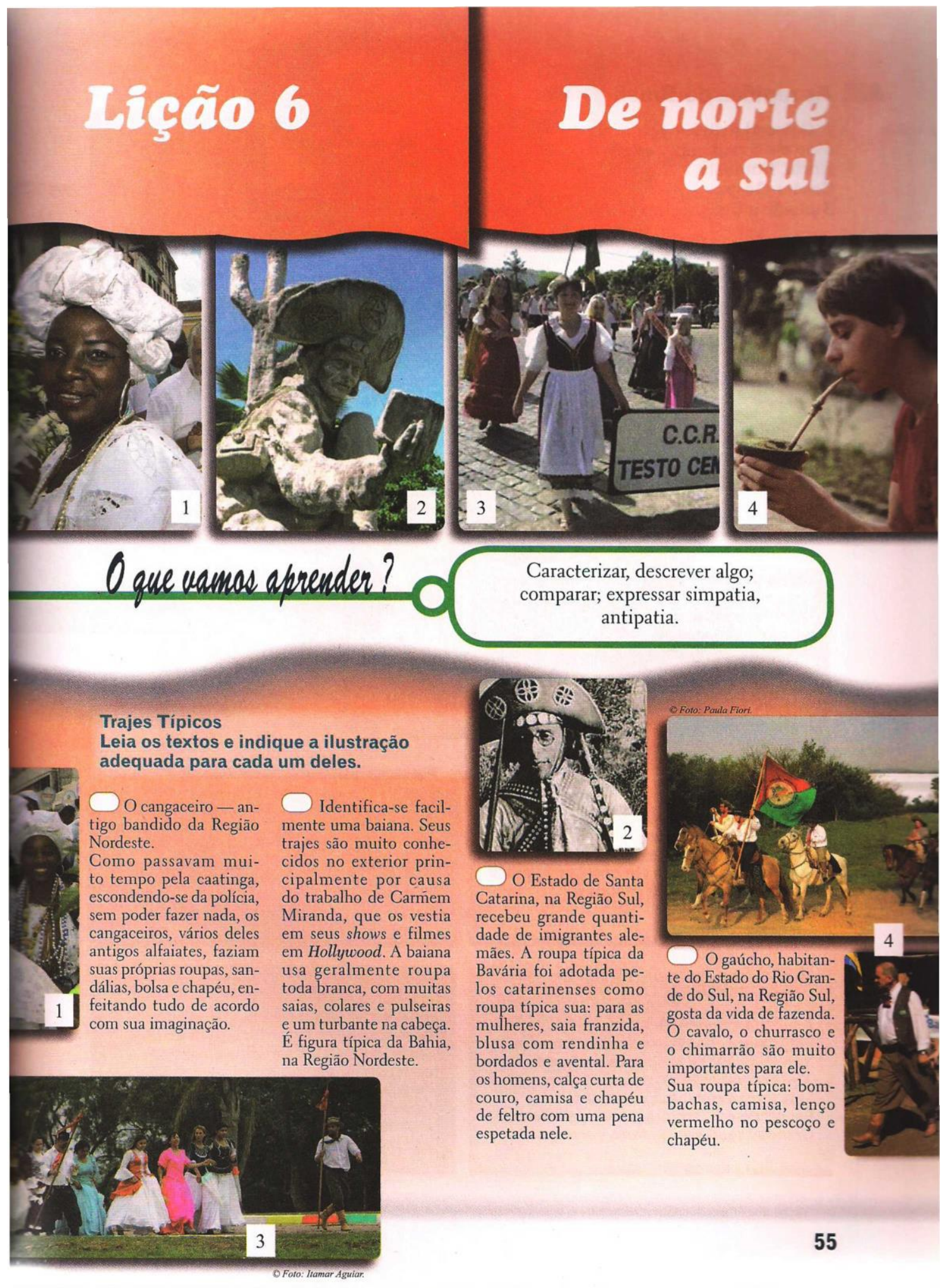


A1 As regiões do Brasil

1. O Brasil é divi-

dido em 5 regiōes:

Norte, Nordeste,

Centro-Oeste,

Sudeste e Sul.

O que

você sabe

sobre elas?
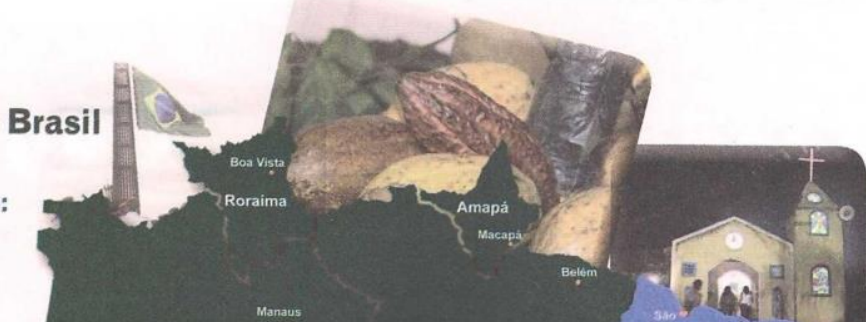

Par:

Amazonas

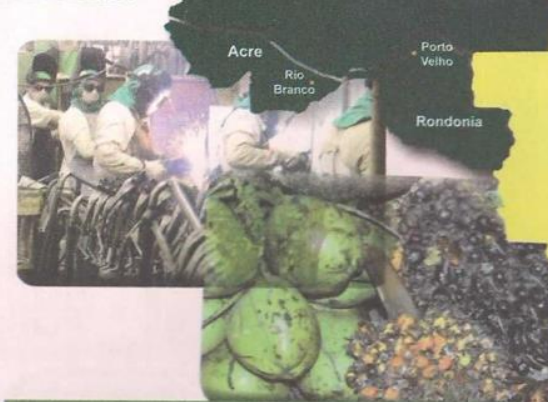

Região Norte

$3,7 \mathrm{hab} . / \mathrm{km}^{2}$ - PIB $5,0 \%$

Atividades econômicas

Extrativismo vegetal: látex, madeira,

castanha, açai

Extrativismo mineral: ouro, diamantes,

ferro, manganês, estanho, cassiterita.

Indústria: parque industrial de montagem

de produtos eletrônicos

Região Centro-Oeste

7,9 hab./km² - PIB 7,4\%

Atividades econômicas

Pecuária extensiva em grandes latifúndios.

Agricultura extensiva em escala comercial.

Extrativismo: Grandes reservas

de manganês.
Regiäo Nordeste

32,4 hab. $/ \mathrm{km}^{2}$ - PIB 13,5\%

Atividades econômicas

Agroindústria do açúcar e do cacau. Exploraçáo de petróleo

Turismo interno nas belas praias da regiaào.

\section{Região Sudeste}

$83,7 \mathrm{hab} . / \mathrm{km}^{2}$ - PIB 56,3\%

Atividades econômicas

Indústria muito diversificada, concen-

trando $49,8 \%$ da produção nacional.

Agropecuária: cana-de-açúcar, laranja,

café, grandes rebanhos bovinos

Extrativismo: Exploração do petróleo.

Grandes reservas de ferro e manganês.

\section{Regiāo Sul}

46,2 hab. $/ \mathrm{km}^{2}$ - PIB $17,8 \%$

Atividades econômicas

Indústria: parque industrial muito ativo.

Agropecuária: agricultura moderna de

trigo, soja, arroz, milho, feijão e tabaco.

Rebanhos bovinos e suinos.

Extrativismo: Madeira de pinho e carvão

mineral. 


\section{A partir das informações da página 56 , responda.}

1. Qual é a região brasileira mais populosa?

E a menos populosa?

A diferença entre elas se mantém também em relação à produção?

2. Em que regiões se explora o petróleo?
3. Em qual das 5 regiões brasileiras o turismo é atividade econômica especialmente importante?

4. Observe as ilustrações abaixo e identifique-as, usando palavras da lista à direita. Em seguida, quando possível, coloque o símbolo nas regiões adequadas.
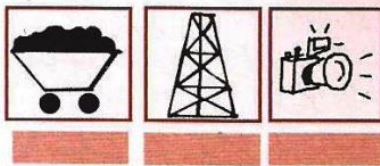

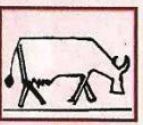

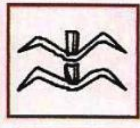

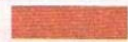
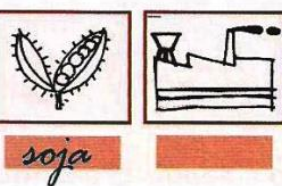

soja
1. petróleo

2. soja

3. gado

4. carvão

5. turismo

6. agricultura

7. induistria

3. Escolha uma das cinco regiões e descreva-a em detalhes, a partir das informações da página 56.

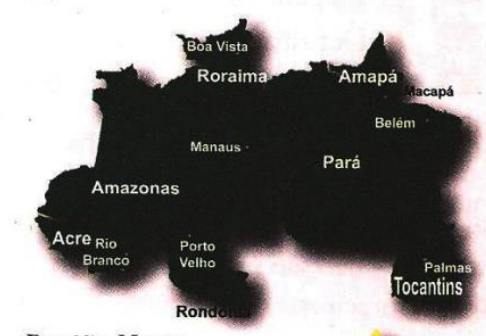

Região Norte

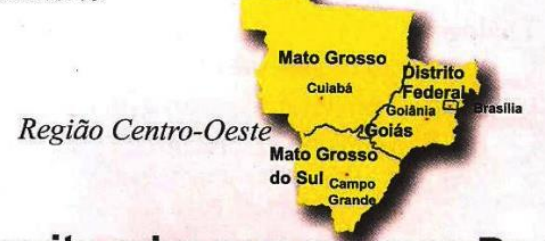

\section{Região Sudeste}
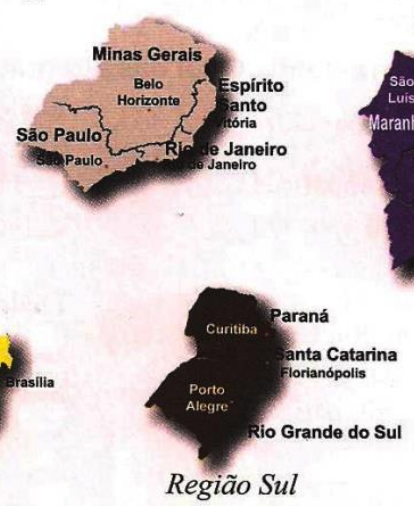

Região Nordeste

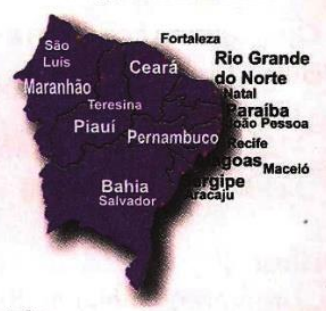

A2 Há muita coisa para se ver no Brasil

\section{Ouça e leia o diálogo.}

- Onde se produz mais vinho?

- Na Região Sul, sem dúvida.

- E onde é encontrado o maior parque industrial brasileiro?

- Na Região Sudeste, principalmente no Estado de São Paulo.

- E o turismo? O que você me diz do turismo?
- O turismo está sendo desenvolvido em todo o país. Cada região tem seus encantos: praias, montanhas, grandes rios, extensas chapadas, selva, cidades históricas ... Há muita coisa para se ver. Férias inesquecíveis podem ser programadas pelo Brasil afora. Questão de gosto.

2. Converse com seu colega. $O$ que há para se ver no país dele? Faça-lhe perguntas, como no diálogo acima. Fale de seu país. 


\section{A3 Estereótipos}

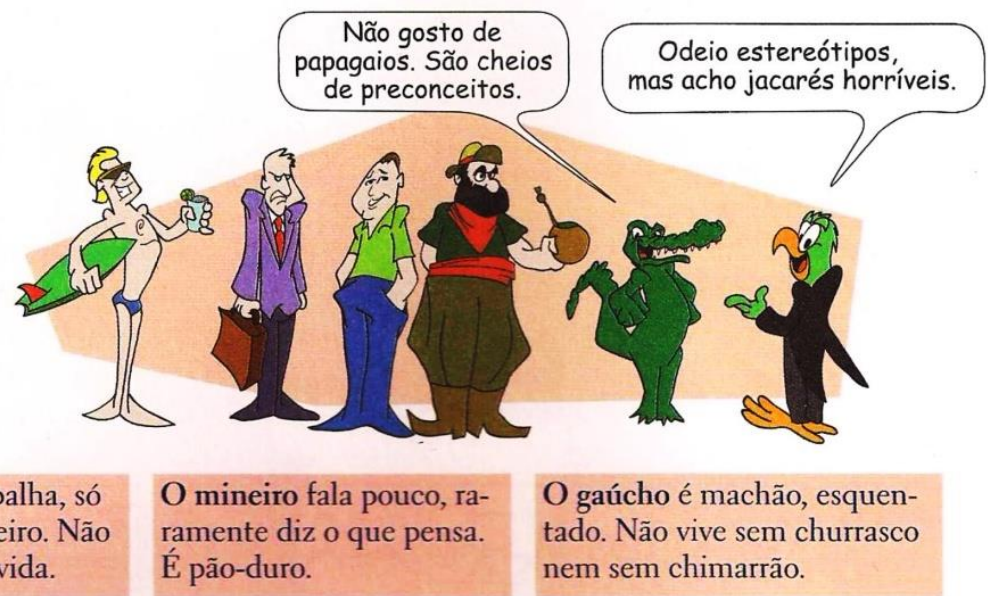

O paulista só trabalha, só quer ganhar dinheiro. Não sabe aproveitar a vida.
É pão-duro. tado. Não vive sem churrasco nem sem chimarrão.

\section{Q. \\ 1. Ouça a gravação e depois classifique estas expressões que aparecem nos diálogos.}

20-24

a) Não suporto ...

b) Acho simpático ...

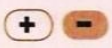

c) Adoro ..

d) Não aguento ...

e) Deus me livre ...

f) Odeio ...

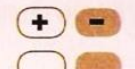

g) Taí gente boa ...

h) Detesto ...

i) Não gosto muito

2. Ouça a gravação novamente. Qual das alternativas contém a ideia do diálogo? Diálogo 1

a) Adoro os cariocas.

Diálogo 4

b) Acho os cariocas simpáticos.

a) É ótimo conversar com mineiros

c) Detesto os cariocas.

b) Os mineiros não são simpáticos.

c) Adoro os mineiros.

Diálogo 2

a) É ótimo morar no Rio Grande do Sul

b) Não aguento os gaúchos.

c) Acho os gaúchos simpáticos

Diálogo 3

a) Não aguento os paulistas.

b) Adoro São Paulo, mas odeio os paulistas.

c) Odeio os paulistas, mas é ótimo morar lá.

\section{Diálogo 5}

a) Adoro os gaúchos.

b) Odeio o churrasco dos gaúchos.

c) Não suporto os gaúchos.

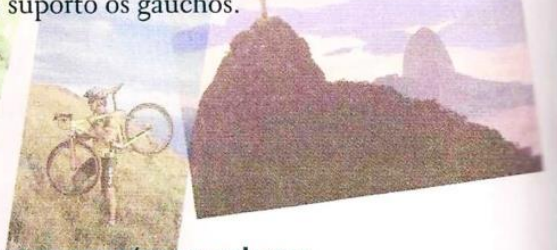

3. Como vocês veem a gente de seu país? Conversem com seus/suas colegas.

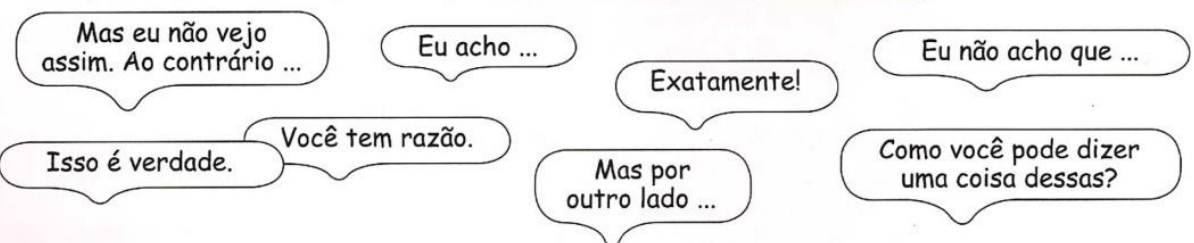


B1 Voz passiva com ser

1. Observe os exemplos e relacione.

poínias alemãs foram fundadas

por imigrantes em Santa Gatarin

As praias do Brasil são procuracias por furistas de fodo o mundo.

Cana-de-açúcar está sendo produzida na regicio Sudeste.

a) O Português

foi descoberto em 1500.

b) Antigamente, as casas serão anunciados amanhã.

c) OBrasil

d) Os resultados

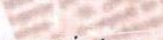

e) Com mais tempo,

f) Os ladrões

\section{Ordene as frases.}

$\square$ Quantas pessoas
A língua que
$\square$ é o chinês.
$\square$ O Brasil

3. Fale com sua/seu colega.
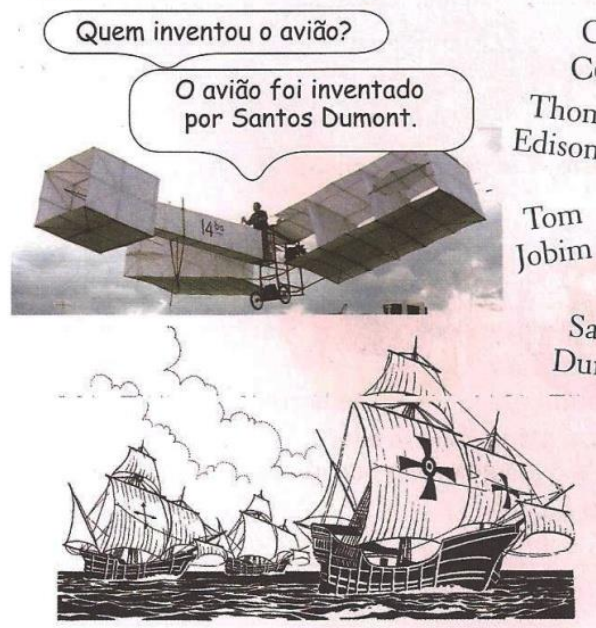

Cristóvão

Colombo

Thomas

Edison José

Tom

Saramago

Jobim

Graham Bell

Santos

Dumont

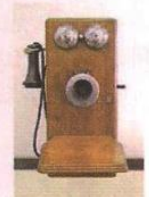

intresenterecute.

ser + particípio

O livro foi escrito há muito tempo.

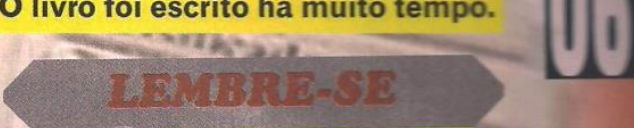

Alguns verbos têm dois particípios (regulares e irregulares).

Os regulares são usados na voz ativa. Os irregulares, na voz passiva.

prender - prendido, preso

aceitar - aceitado, aceito

entregar - entregado, entregue

limpar - limpado, limpo

matar - matado, morto

pegar - pegado, pego

acender - acendido, aceso

soltar - soltado, solto

Ex.: A polícia já tinha prendido

o ladrão quando seu chefe foi

preso.

$\square$ estão sendo esperadas

por Pedro Álvares Cabral

por mais pessoas no mundo 


\section{B2 Voz passiva com -se}

1. Observe os exemplos e depois complete os anúncios com os verbos.

Alugam-se casas com vista para o mar. - Casas com vista para o mar são alugadas.

Fala-se português em vários países. - Português é falado em vários países.

Perderam-se documentos importantes. - Documentos importantes foram perdidos.

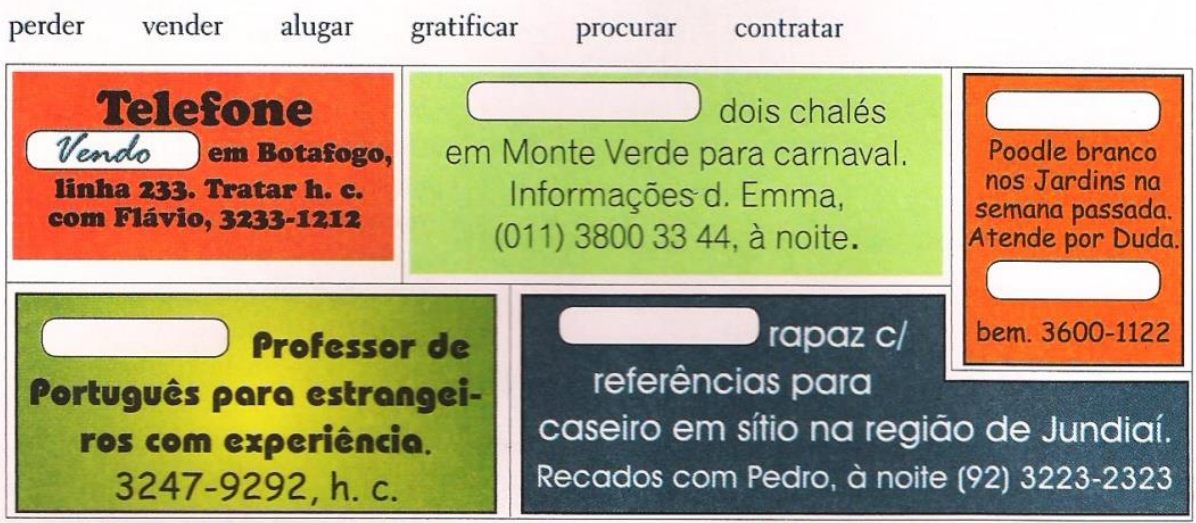

2. Como se troca um pneu? Complete.

(soltar parafusos) (levantar o carro) (retirar parafusos) (tirar o pneu) (colocar o estepe)
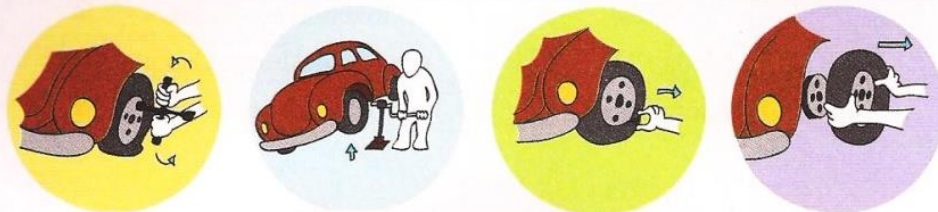

Primeiro soltam-se Depois,

Então,

Agora,

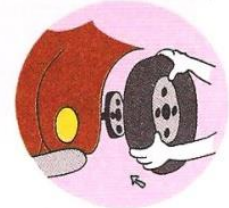

os

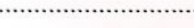

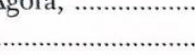

e

(colocar parafusos) (apertar parafusos) (descer o carro) (guardar o pneu)

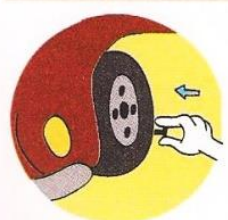

Depois,

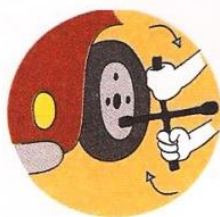

Agora,

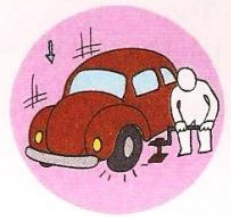

$\mathrm{e}$

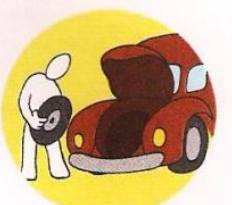

Agora, só falta guardar o pneu. 


\section{B3 Pronomes indefinidos}

1. todo/a - todos os - todas as - tudo

Exemplo: Tudo está em ordem no escritório.

\begin{tabular}{|l|l|l|l|}
$\begin{array}{l}\text { Todo dia } \\
\text { Todos os dias } \\
\text { Toda semana } \\
\text { Todas as semanas }\end{array}$ & ela vai ao escritório. & Ela trabalha lá & $\begin{array}{l}\text { o dia todo. } \\
\text { a semana toda. }\end{array}$ \\
\hline
\end{tabular}

a) Traduza as frases acima para sua língua.

b) Faça frases.

\begin{tabular}{|l|c|l|}
\hline Ela trabalha & & no supermercado \\
Nós fazemos ginástica & todo & dia(s) \\
Eu faço mergulho & toda & mês(es) \\
Eles viajam para o Brasil & todos os & verão \\
Elas sabem & todas as & ano(s) \\
Ele compra & tudo & sobre astrofísica \\
A professora come feijoada & & férias \\
Meu vizinho toca piano & & semana \\
\hline
\end{tabular}

c) Escreva de outra maneira.

Ele leu o livro do começo ao fim.

Ele len o limo todo.

Ela dormiu das 8 às 20 horas.

No sábado, não saí de casa.

Eles ficam em Porto Alegre de $2^{\mathrm{a}}$ a domingo.

Ele vendeu todas as coisas que tinha.

\section{2. cada}

Todas as crianças gostam de chocolate.

\section{Faça frases.}

\begin{tabular}{|l|c|l|}
\hline Cada & aluno(s) & $\begin{array}{l}\text { vão participar do projeto. } \\
\text { vai receber uma tarefa diferente. } \\
\text { são lindos. }\end{array}$ \\
Todos os & entrada(s) & $\begin{array}{l}\text { custa uma fortuna. } \\
\text { para o show foram vendidas. } \\
\text { custou um absurdo. }\end{array}$ \\
Tudo as & quadro(s) & \\
\hline
\end{tabular}




\section{C1 Influências na cultura brasileira}

Relacione as palavras com as fotos.
(1) língua
(2) culinária
(3) religiåo
(4) dia a dia
(5) música
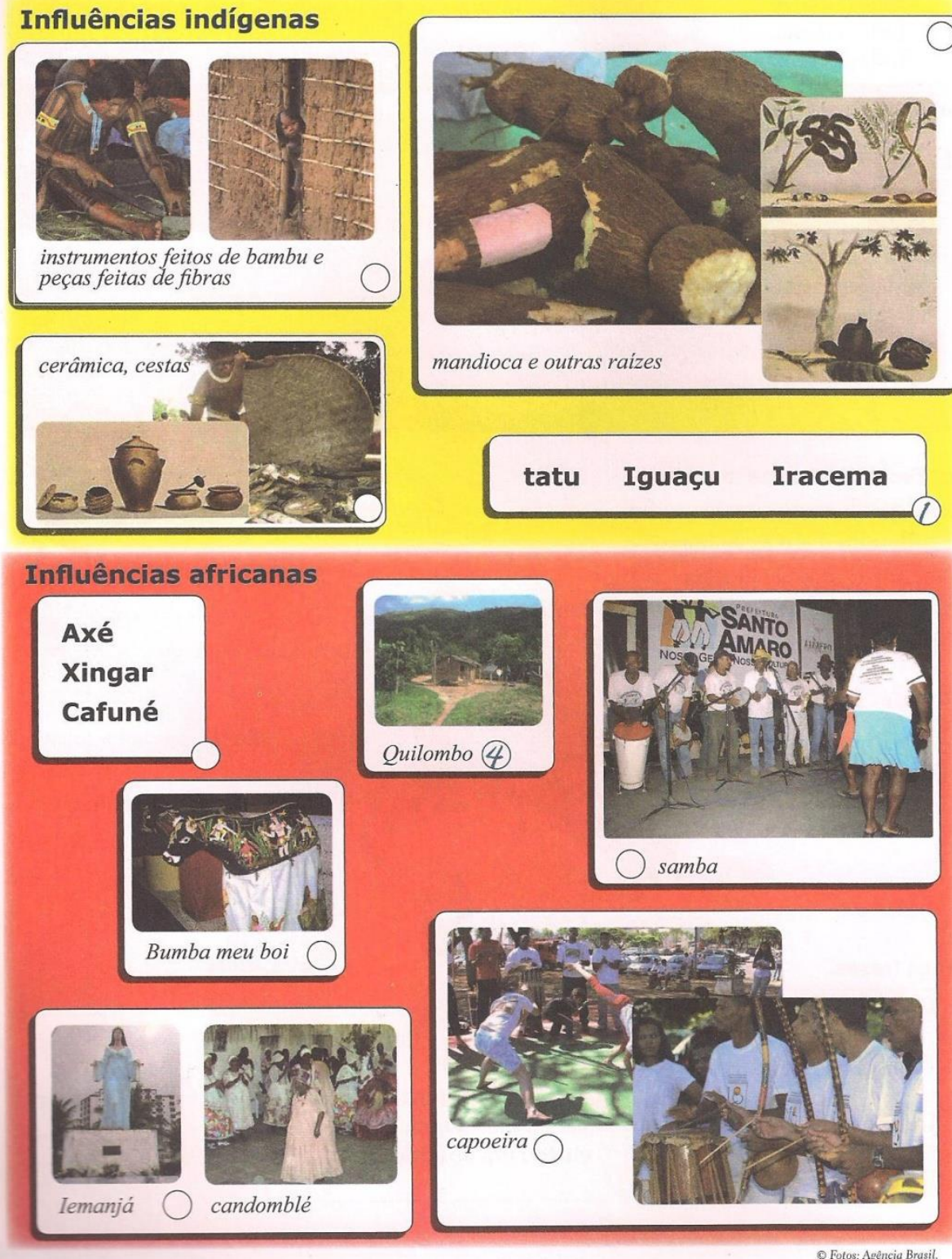

62 


\section{Culinária}

No regime alimentar brasileiro, a contribuição africana se afirmou principalmente pela introdução do azeite de dendê e da pimentamalagueta, tão característico da cozinha baiana; pela introdução do quiabo; pelo maior uso da banana; pela grande variedade na maneira de preparar a galinha e o peixe. Várias comidas portuguesas ou indígenas foram, no Brasil, modificadas pela condimentação ou pela técnica culinária do negro. Alguns dos pratos mais caracteristicamente brasileiros são de técnica africana: a farofa, o quibebe, o vatapá. Das comidas preparadas pela mulher indígena, as principais eram as que se faziam com a massa ou a farinha de mandioca. Do milho, preparavam, além da farinha, a canjica e a pamonha.

Do peixe ou da carne picada e misturada com farinha, faziam a paçoca. Moqueca é peixe assado no rescaldo e vem todo embrulhado em folha de bananeira.

Baseado em "Casa Grande e Senzala" de Gilberto Freyre.
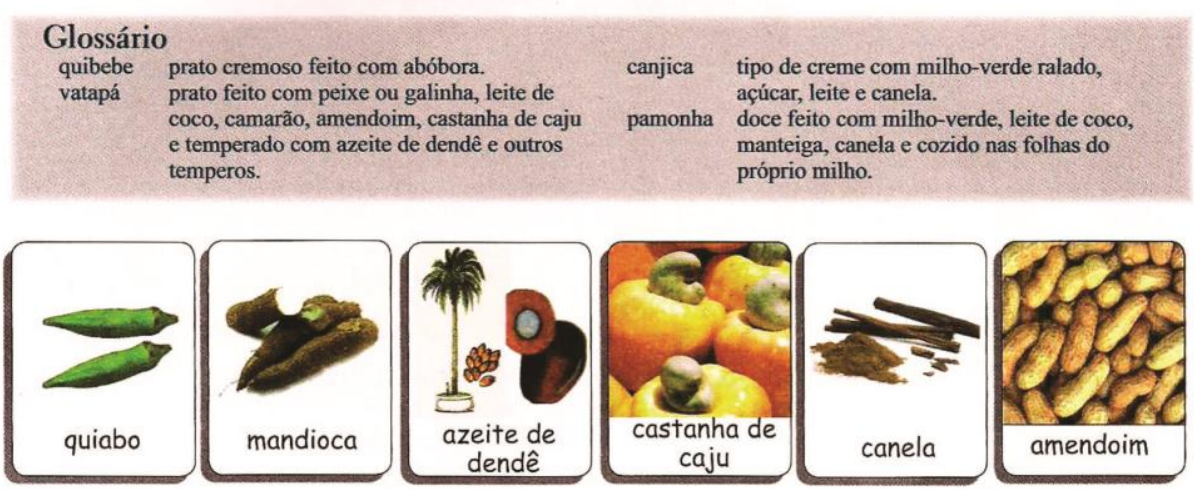

\section{Procure no texto:}

Ingredientes e pratos da cozinha africana.

Ingredientes e pratos da cozinha indígena

\section{Fale com suas/seus colegas.}

Que pratos estrangeiros são comuns em seu país?

Qual é o prato mais exótico que você já experimentou?

Que prato brasileiro você conhece?

3. De que tipo de comida você gosta ou não gosta?

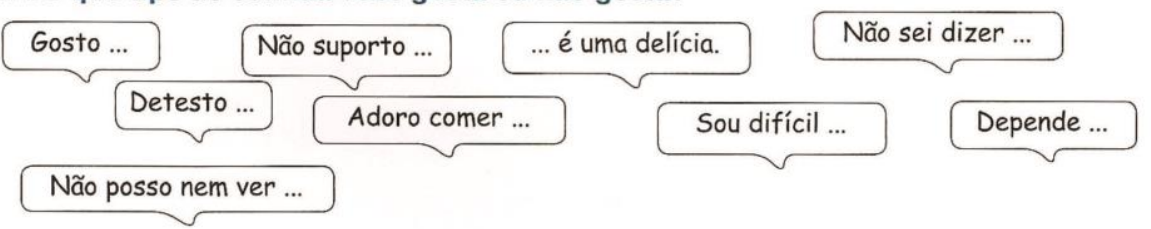


D1 Bumba meu boi

A tradição no Maranhão

Junho é mês de festa no Maranhão. Na maioria brasileiros. A representação completa do auto tem das cidades, bandeirinhas, fitas e balões enfeitam uma duracão aproximada de oito horas, devido à as ruas e um ritmo vibrante toma conta das praças, repetição das cenas. Mas o enredo da festa narra levando milhares de pessoas aos arraiais. uma história bem simples: as desventuras de Não se trata de uma festa junina um casal de negros escravos. comum. Na capital, São Luís, ou em muitos povoados do interior, o dia 23 dá início a um dos espetáculos mais puros do Nordeste - as apresentações do Bumba meu boi, que se estendem até 29 de junho, dia de São Pedro. O Maranhão para nesta época. E o ponto alto de uma festa que começa a ser organizada em agosto, depois de muita teatralizac̃ para ressurreição do boi, mas é na semana de 23 a 29 de junho que os conjuntos de Bumba meu boi mostram a melhor parte de sua arte é encenação - as danças de rua e as toadas. Apesar de alguma influências europeias, o espetáculo conta com estrutura, tipos, temas e músicas essencialmente

\section{Leia o primeiro parágrafo do texto.}

Em que época acontece o Bumba meu boi?

No início da primavera.

No início do verão.

No início do inverno.

\section{Leia o segundo parágrafo.}

O Bumba meu boi é uma ...

\section{festa de tradição europeia.}

festa de rua com teatro, dança e música.

peça de teatro.

\section{D2 Em algum lugar do Brasil}

1. Lembra os tipos brasileiros que você conheceu na página 55 ? Você vai ouvir uma conversa. Onde estão conversando?

No Rio.

Em Minas Gerais.

No Rio Grande do Sul.

2. Ouça novamente. Eles falam sobre.

otempo $\bigcirc$ a cidade $\bigcirc$ otrânsito política $\bigcirc$ leite

\section{Quais são os personagens principais do} Bumba meu boi?

\section{Coloque os fatos na ordem em que} acontecem.

Pai Francisco é preso.

Todos estão felizes novamente.

(1) O patrão quer saber o que aconteceu.

Pai Francisco tem que devolver o boi.

Todos trabalham para ressuscitar o boi.

O boi volta à vida.

\section{O que você ouve no diálogo?}

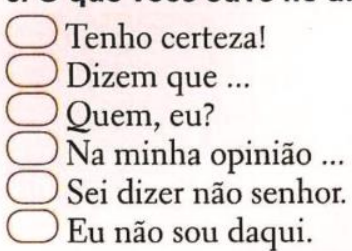

4. Que formas existem na sua língua para fugir a uma resposta? Pergunte ao/a professor/a como seriam em português.

64 


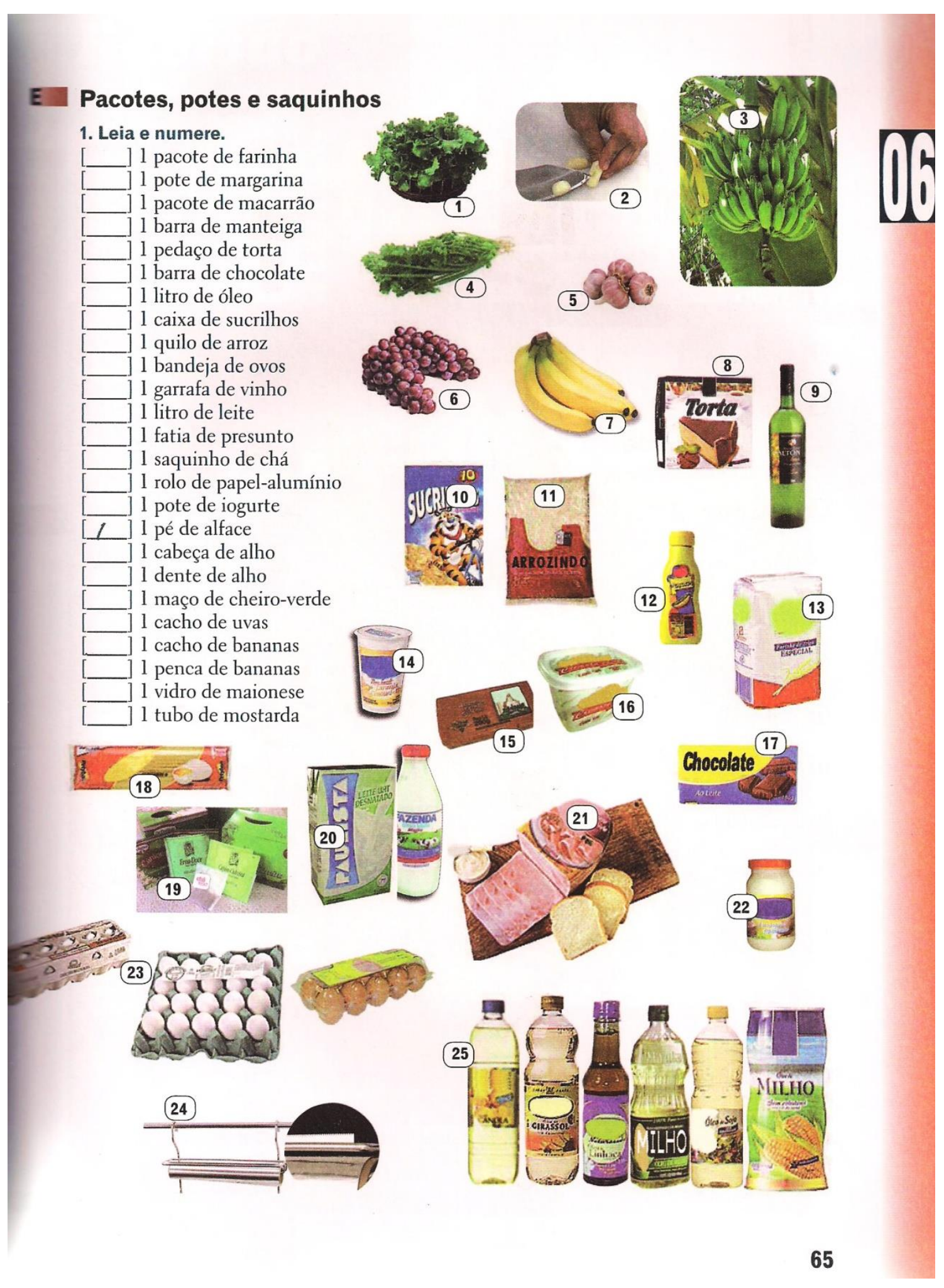




\section{Leia e relacione.}

(1) Um pacote

(2) Uma barra

(3) Um tablete

(4) Uma lata

(5) Uma caixa

(6) Um quilo

(7) 100 gramas

(8) Uma dúzia

(9) Uma garrafa

(10) Um litro

(11) Um saquinho

(12) Um rolo

(13) Um maço

(14) Um vidro

(15) Um pé

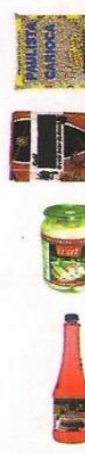

de
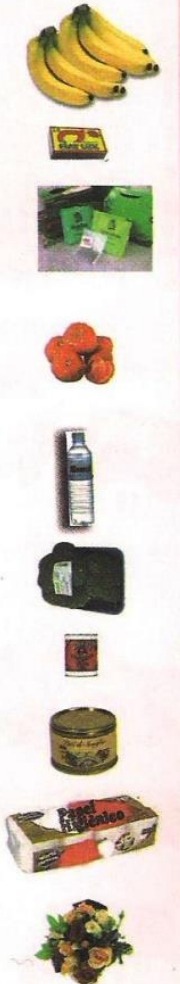

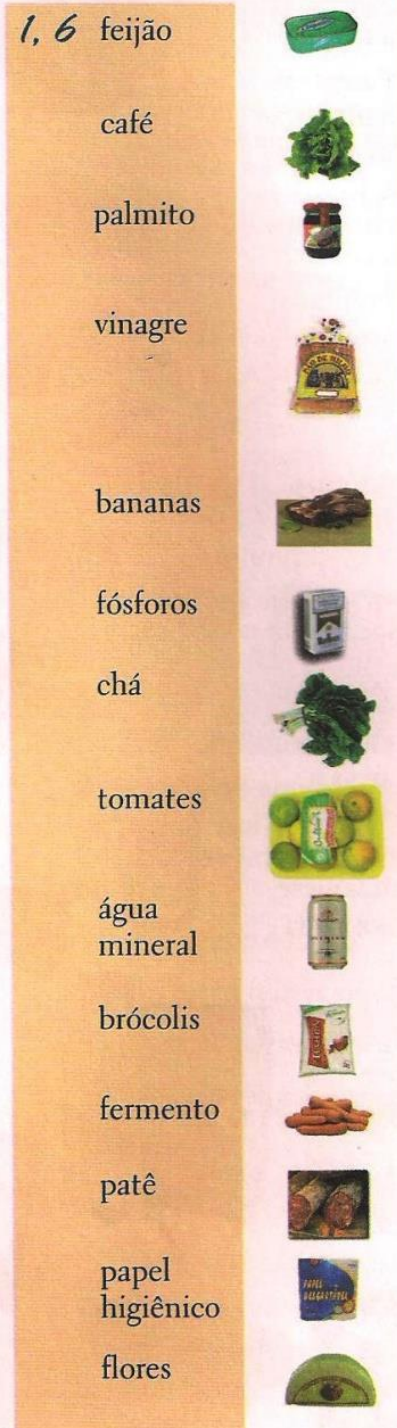

sardinhas

alface

geleia

pão

carne

cigarros

espinafre

laranjas

cerveja

açúcar

cenoura

salame

papel

toalha

queijo

parmesão

3. Trabalhe com seu/sua colega. Você vai ao supermercado fazer suas compras do mês. Faça uma lista do que você precisa.

\section{Você quer fazer seu prato favorito, mas não tem nada em casa. $O$ que você vai comprar?}

